\title{
IDENTIFICAÇÃO E CARACTERIZAÇÃO DO COMPORTAMENTO FÍSICO DE SOLOS COESOS NO ESTADO DO CEARÁ
}

\author{
HERDJANIA VERAS DE LIMA
}

\footnotetext{
Tese apresentada à Escola Superior de Agricultura

"Luiz de Queiroz", Universidade de São Paulo, para obtenção do título de Doutor em Agronomia, Área de Concentração: Solos e Nutrição de Plantas.
}

P I R A C I C A B A

Estado de São Paulo - Brasil

Janeiro - 2004 


\title{
IDENTIFICAÇÃO E CARACTERIZAÇÃO DO COMPORTAMENTO FÍSICO DE SOLOS COESOS NO ESTADO DO CEARÁ
}

\section{HERDJANIA VERAS DE LIMA}

Engenheiro Agrônomo

\author{
Orientador: Prof. Dr. ÁLVARO PIRES DA SILVA
}

\author{
Tese apresentada à Escola Superior de Agricultura \\ “Luiz de Queiroz”, Universidade de São Paulo, para \\ obtenção do título de Doutor em Agronomia, Área de \\ Concentração: Solos e Nutrição de Plantas.
}

P I R A C I C A B A

Estado de São Paulo - Brasil

Janeiro - 2004 
Dados Internacionais de Catalogação na Publicação (CIP)
DIVISÃO DE BIBLIOTECA E DOCUMENTAÇÃO - ESALQ/USP

Lima, Herdjania Veras de

Identificação e caracterização do comportamento físico de solos coesos no

Estado do Ceará / Herdjania Veras de Lima. - - Piracicaba, 2004.

85 p. : il.

Tese (doutorado) - Escola Superior de Agricultura Luiz de Queiroz, 2004.

Bibliografia.

1. Física do solo 2. Micromorfologia do solo 3. Resistência dos solos 4. Solo coeso (Ceará) 5. Tabuleiro costeiro I. Título

CDD 631.44

"Permitida a cópia total ou parcial deste documento, desde que citada a fonte - $O$ autor" 
Aos meus pais, Edval e Avani, e aos meus irmãos, Herdnan e Jânio, que tanto me incentivaram e me apoiaram para a realização deste trabalho.

DEDICO E OFEREÇO. 


\section{AGRADECIMENTOS}

Ao professor Álvaro Pires da Silva, pelos ensinamentos, orientação, apoio e amizade;

Ao Conselho Nacional de Desenvolvimento Científico e Tecnológico (CNPq), pela concessão da bolsa de estudo;

Ao professor Mauro Carneiro da Universidade Federal Rural de Pernambuco (UFRPE), pela disponibilidade do laboratório de micromorfologia;

Ao professor Ricardo Romero da Universidade Federal do Ceará pela ajuda nos trabalhos de campo e pelas sugestões;

Ao professor Paulo Klinger T. Jacomine pela grande colaboração neste trabalho;

Aos professores Paulo Libardi, Assis Júnior que auxiliaram as viagens de campo, através do projeto de cooperação acadêmica entre cursos de pós-graduação da ESALQ/USP e do CCA/UFC (PROCAD 2000 da CAPES);

Aos funcionários do Departamento de Solos e Nutrição de Plantas da ESALQ/USP, pelo apoio nas atividades desenvolvidas;

Aos colegas Tairone, Cláudia, Débora, Flávia, Sílvia, Luís Gonzaga, Pereira Júnior, pelo auxílio e amizade;

A todos que de algum modo contribuíram para a realização deste trabalho.

Obrigada. 


\section{SUMÁRIO}

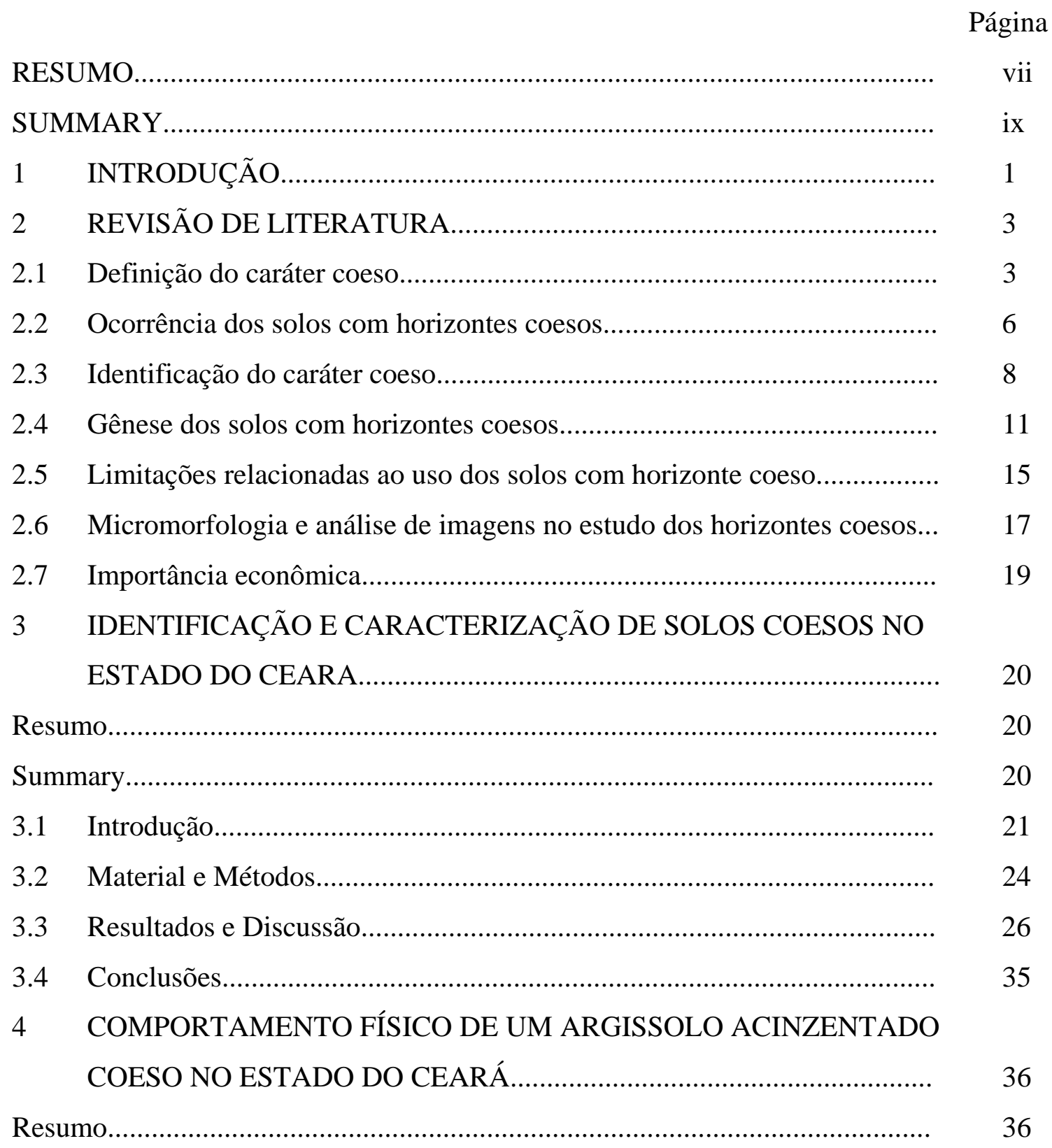




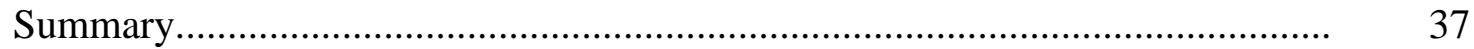

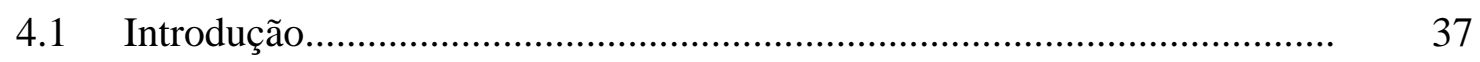

4.2 Material e Métodos........................................................................... 39

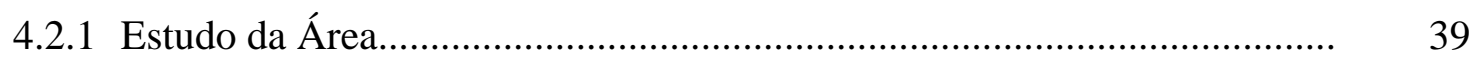

4.2.2 Determinação da resistência tênsil.............................................................. 40

4.2.3 Curva de resistência do solo à penetração.................................................... 41

4.2.4 Distribuição da porosidade do solo............................................................. 41

4.2.5 Análises estatísticas................................................................................ 42

4.3 Resultados e Discussão........................................................................... 42

4.3.1 Resistência tênsil (RT) ...............................................................................

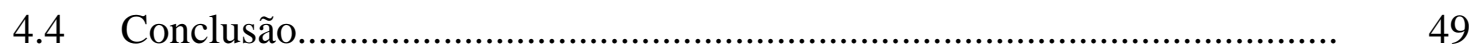

5 MICROMORFOLOGIA E ANÁLISE DE IMAGENS DE UM ARGISSOLO ACINZENTADO COESO NO ESTADO DO CEARÁ...... 50

Resumo......................................................................................... 50

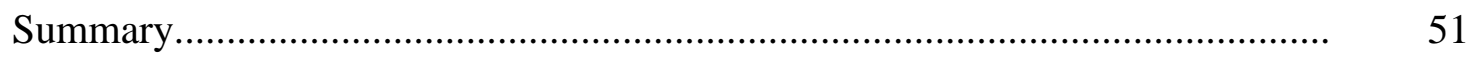

5.1 Introdução..................................................................................... 51

5.2 Material e Métodos................................................................................... 53

5.3 Resultados e Discussão...................................................................... 5

5.3.1 Descrição micromorfológica....................................................................... 57

5.3.2 Análise de imagens................................................................................. 62

5.4 Conclusão....................................................................................

6 CONCLUSÕES GERAIS................................................................

REFERÊNCIAS BIBLIOGRÁFICAS............................................................... 


\title{
IDENTIFICAÇÃO E CARACTERIZAÇÃO DO COMPORTAMENTO FÍSICO DE SOLOS COESOS NO ESTADO DO CEARÁ
}

\author{
Autora: HERDJANIA VERAS DE LIMA \\ Orientador: Prof. Dr. ÁLVARO PIRES DA SILVA
}

\section{RESUMO}

Os solos coesos ocorrem por quase toda a faixa litorânea brasileira ocupada pelos Tabuleiros Costeiros, e caracterizam-se por apresentar um incremento acentuado na sua resistência, a qual causa restrições no seu preparo e no crescimento das plantas. Isso ocorre devido ao mesmo apresentar-se duro a extremamente duro, quando seco e friável quando úmido. Dentre os Estados da região nordeste que possuem uma extensa área litorânea ocupada pelos Tabuleiros está o Ceará, com mais de 10.000 km² ocupados por solos que podem ser enquadrados dentro do contexto de solos coesos. Com isso levantou-se a hipótese de que os solos coesos do Estado do Ceará apresentam as mesmas restrições físicas e químicas encontradas em outros solos pertencentes aos Tabuleiros Costeiros. O objetivo geral desta tese foi identificar a ocorrência de solos coesos no Estado do Ceará, bem como, avaliar o seu comportamento através do uso de atributos morfológicos, físicos, micromorfológicos e análise de imagens. Para alcançar o objetivo geral foram estabelecidos três objetivos específicos. Cada objetivo específico contemplou um trabalho e é apresentado como um capítulo desta tese. No primeiro procurou-se identificar e caracterizar a ocorrência de solos coesos no Ceará, usando atributos morfológicos, químicos e físicos. 
No segundo, foi feita uma análise do comportamento de um Argissolo Acinzentado coeso através do uso de atributos físicos, especificamente: resistência tênsil (RT), resistência do solo à penetração (RP), densidade do solo (Ds) e distribuição da porosidade total (PT). No terceiro e último trabalho realizou-se um detalhamento microscópico dos solos estudados, dando ênfase à distribuição, tamanho e orientação dos poros nas áreas adensadas e abertas (menos adensadas) do horizonte coeso, através do uso da análise de imagens. Os resultados do primeiro trabalho mostraram que os horizontes coesos encontrados no Ceará, apresentam-se semelhantes aos horizontes coesos encontrados em outros Estados brasileiros. Os resultados referentes ao segundo trabalho evidenciaram que os valores de RT, RP e Ds, mostraram-se mais elevados no solo coeso do Ceará, do que em outras áreas de Tabuleiros Costeiros estudadas no Brasil. No terceiro trabalho foi observado que o adensamento natural existente nos horizontes coesos do Ceará, além de influenciar a quantidade de poros, também influencia o seu formato e a sua orientação, e que as áreas adensadas, medidas por análise de imagem, foram os principais fatores que influenciaram o espaço poroso do solo, sendo responsável pelo aumento na resistência do solo.

Palavras-chave: Tabuleiros Costeiros no Estado do Ceará, solos coesos, resistência do solo à penetração, resistência tênsil, micromorfologia e análise de imagens. 


\title{
IDENTIFICATION AND CHARACTERIZATION OF THE PHYSICAL BEHAVIOR OF HARDSETTING SOILS IN THE STATE OF CEARA
}

\author{
Author: HERDJANIA VERAS DE LIMA \\ Adviser: Prof. Dr. ÁLVARO PIRES DA SILVA
}

\section{SUMMARY}

The hardsetting soils may be found for almost the whole Brazilian coastal area of the Coastal Tablelands. They are characterized by presenting an accentuated increment in their mechanical resistance, which causes restrictions in the soil preparation and in the plants growth. These happen due to hardsetting soils become hard to extremely hard when dry, and crumbly when humid. Ceara is one of the northeast States that possess an extensive coastal area of Coastal Tablelands, with more than $10.000 \mathrm{~km}^{2}$ of hardsetting soils. Taking this into account, it was hypothesized that hardsetting soils of Ceara State had the same physical and chemical restrictions identified in hardsetting soils in other of Coastal Tablelands. The general objective of this thesis was to identify the occurrence of hardsetting soils in the Ceara State as well as to evaluate their behavior by using the morphological, physical, and micromorphological attributes, and image analysis. To accomplish the general objective three specific objectives were established. Each specific objective led to the accomplishment of one research, and is presented as a chapter of this thesis. In the first research was identified and characterized the occurrence of hardsetting soils in Ceara by using morphologic, chemical and physical attributes. In the second research, it was studied the behavior of a hardsetting Gray 
Argisol by using soil physical attributes, specifically: tensile strength (RT), soil resistance to penetration (RP), soil bulk density (Ds), and pore size distribution (PT). In the last research, the soil micromorphological features were studied, giving emphasis to the distribution, size and orientation of the pores in the more denser and less denser areas of the hardsetting horizon, by using image analysis. The results of the first research showed that the hardsetting horizons found in Ceara are similar to the hardsetting horizons found in other Brazilian States. The results regarding the second research indicated that the RT, RP and Ds values were higher in the hardsetting soil of Ceara than those measured in other hardsetting soils of the Coastal Tablelands. In the third research was observed that the existent natural compaction in the hardsetting horizons of Ceara influences the amount of pores as well as their shape and orientation, and that the denser areas, measured by image analysis, were the main factor that influenced the soil porosity, being responsible for the increase in the soil mechanical resistance.

Key words: Coastal Tablelands in the State of Ceara, hardsetting soils, soil resistance to penetration, tensile strength, micromorphology and image analysis. 


\section{INTRODUÇÃO}

O termo coeso tem sido utilizado no Brasil para designar horizontes minerais subsuperficiais do solo que apresentam um aumento acentuado na coesão entre as suas partículas, tornando-se duro, muito duro ou até extremamente duro quando seco e friável quando úmido (Jacomine, 1996).

A ocorrência do caráter coeso, no Brasil, está relacionada com os sedimentos da Formação Barreiras, os quais estão geologicamente relacionados com os depósitos sedimentares do período Terciário, que constituem a unidade geomorfológica dos Tabuleiros Costeiros. Os solos sob esta formação estão restritos à zona úmida costeira do litoral oriental das regiões norte, nordeste e sudeste, sob climas de estações secas e úmidas bem definidas (Jacomine, 2001; Giarola \& Silva, 2002).

A gênese desses solos está associada a vários processos, tais como: agrupamento de partículas de argila face a face; perda do plasma argiloso da camada superficial para as subjacentes (argiluviação); presença de compostos orgânicos pouco polimerizados; presença de sílica secundária, ferro e alumínio dispersos nos microporos; adensamento resultante da alteração da estrutura do solo pela alternância de ciclos de umedecimento e secagem e contribuição da areia fina (UFV, 1984; Ribeiro, 1986; Ponte \& Ribeiro, 1990; Jacomine, 1996; Ferreira et al., 1999a; Araújo Filho et al., 2001; Rezende et al., 2002).

Os horizontes coesos são reconhecidos como potencialmente limitantes ao desenvolvimento das plantas, devido à elevada resistência do solo à penetração quando seco, o que afeta o desenvolvimento do sistema radicular das plantas, o teor de água disponível, a aeração e a absorção de nutrientes, constituindo um inibidor físico e influenciando negativamente a produção agrícola (Rezende, 2000; Cintra et al., 1997). A sua pobreza em nutrientes associada com a alta saturação por alumínio e a alta acidez 
ativa e trocável constitui também um inibidor químico, dificultando além do desenvolvimento radicular a atividade microbiana do solo (Rezende, 2000; Souza, 1997).

Dentre os Estados da região nordeste que possuem uma extensa área litorânea ocupada pelos Tabuleiros está o Ceará (Rezende, 2000), com mais de 10.000 km² ocupados por solos derivados da Formação Barreiras e que se enquadram dentro do contexto de solos coesos (Jacomine et al., 1973). Sua importância social e econômica é justificada pelas grandes concentrações urbanas e pela grande exploração agrícola.

Apesar dos levantamentos de solos no Ceará já terem constatado características morfológicas semelhantes as que ocorrem nos horizontes coesos (Melo, 1968; Jacomine et al., 1973), nenhum estudo que comprovasse a ocorrência desses solos, ou mesmo, que verificasse a sua semelhança com outros solos coesos estudados no Brasil foi realizado, já que as pesquisas sobre o assunto estão concentradas nas áreas de tabuleiros compreendidas entre os Estados de Pernambuco e Espírito Santo.

A literatura sugere que os solos coesos ocorrem por quase toda a faixa costeira do Brasil, abrangendo desde o Estado do Amapá até o Rio de Janeiro (Jacomine, 1996). Assim, com o intuito de prosseguir e ampliar os estudos realizados nos solos que apresentam horizontes coesos, levantou-se a hipótese de que os solos coesos também ocorrem no Estado do Ceará e apresentam as mesmas restrições físicas e químicas encontradas em outros solos pertencentes aos Tabuleiros Costeiros.

O objetivo geral desta tese foi identificar a ocorrência de solos coesos no Estado do Ceará, bem como, avaliar o seu comportamento através do uso de atributos físicos, macro e micromorfológicos e análise de imagens. Para alcançar o objetivo geral, a pesquisa foi subdividida em capítulos, sendo que cada capítulo contemplou um trabalho distinto. No primeiro capítulo procurou-se identificar e caracterizar a ocorrência de solos coesos no Ceará, usando atributos morfológicos, químicos e físicos. No segundo capítulo, foi feita uma análise do comportamento de um Argissolo Acinzentado coeso através do uso de atributos físicos, especificamente: resistência tênsil, resistência do solo à penetração, densidade do solo e distribuição da porosidade total. No terceiro e último capítulo observou-se o detalhamento microscópico dos solos estudados, dando ênfase à distribuição, ao formato, tamanho e orientação dos poros nas áreas adensadas e abertas do horizonte coeso, através do uso da análise de imagens. 


\section{REVISÃO DE LITERATURA}

\subsection{Definição do caráter coeso}

Diversos estudos no Brasil têm reconhecido uma forma particular de comportamento do solo, conhecido como caráter coeso, o qual apresenta-se através de um aumento acentuado na coesão entre as partículas do solo, tornando-o duro, muito duro ou até extremamente duro quando seco e friável quando úmido (Jacomine, 1996; Rezende, 2000).

Ribeiro (1991) definiu os horizontes que apresentam o caráter coeso como: “horizontes muito duros a firmes, que não apresentam organização estrutural visível (são maciços), motivo pelo qual os grandes torrões se quebram em fragmentos de tamanhos menores e angulosos; apresentam uma macroporosidade geralmente ligada à atividade biológica (biovazios), sendo difícil a observação dos poros finos; no seu interior são raras as raízes observadas, mesmo assim, a grande maioria das que conseguiram penetrar nesses horizontes encontram-se mortas; em alguns pontos pode-se observar uma organização estrutural fragmentar, com a presença de estrutura do tipo blocos subangulares, geralmente associados a pequenas concentrações de material orgânico originado da decomposição de raízes ou atividade biológica (crotovinas e ninhos); em muitos casos é possível observar, ainda que com alto grau de dificuldade, e com uso de lupa, a existência de uma microestrutura soldada, como uma colméia de abelhas”.

O caráter coeso foi atribuído a classe dos Latossolos Amarelos como característica diagnóstica pelo atual Sistema Brasileiro de Classificação de Solos (Embrapa, 1999), o qual considera coesos os solos com um ou mais horizontes com espessura mínima de 0,3 m, que não satisfaça os critérios para fragipã e duripã, 
compreendendo o horizonte $\mathrm{AB}$ e/ou $\mathrm{BA}$, e/ou parte do $\mathrm{Bw}$, os quais, quando secos, são muito resistentes à penetração do martelo pedológico ou trado e que não apresentam organização estrutural visível (são maciços) e que se desfaz em agregados, com consistência a seco, no mínimo, dura, sendo normalmente muito dura, e às vezes, extremamente dura. A consistência úmida varia de friável a firme; a densidade do solo deste horizonte é mais elevada que os horizontes subjacentes; a saturação por bases é baixa $\left(\mathrm{V}<50 \%\right.$ ), e o teor de $\mathrm{Fe}_{2} \mathrm{O}_{3}$ (pelo $\mathrm{H}_{2} \mathrm{SO}_{4}$ ) é menor que $80 \mathrm{~g} \mathrm{~kg}^{-1}$ e o $\mathrm{Ki}$ é 1,7 ou maior, isto é, são cauliníticos.

Embora o Sistema Brasileiro de Classificação de Solos (Embrapa, 1999) considere o termo "coeso" apenas para a classe dos Latossolos Amarelos, há registro de ocorrência desse comportamento em Argissolos Amarelos e Argissolos Acinzentados (Jacomine, 2001; Cintra \& Libardi, 1998).

De acordo com Jacomine (2001), o horizonte que apresenta o caráter coeso é um horizonte pedogenético, adensado, muito duro ou extremamente duro quando seco e normalmente friável quando úmido, que quando seco, desmancha-se ao ser imenso em água. Uma amostra úmida ao ser pressionada entre os dedos deforma-se lentamente. Este aspecto é que difere o horizonte coeso do fragipã, o qual quando úmido, tem uma quebradicidade fraca e seus elementos estruturais ou fragmentos apresentam tendências de romperem-se subitamente, sob pressão, em vez de sofrerem uma deformação lenta. O fragipã quando imerso em água torna-se menos resistente, podendo desenvolver fraturas com ou sem desprendimento de pedaços, e se esboroa em curto espaço de tempo $( \pm 2$ horas) (Embrapa, 1999).

O horizonte coeso normalmente encontra-se abaixo do horizonte A, entre 0,3 e 0,6 m de profundidade, podendo, no entanto, atingir até 1 metro ou pouco mais, sobretudo nos solos com horizonte B textural (Argissolos), mas também pode encontrarse na superfície devido à erosão do horizonte superior (Jacomine, 2001; Jacomine, 1996).

De acordo com Ribeiro, M. (2001) o horizonte coeso é típico dos Latossolos Amarelos Coesos e Argissolos Amarelos latossólicos ou não, ocorrendo menos freqüentemente em Argissolos Acinzentados e Argissolos Amarelos fragipânicos, sendo 
originados essencialmente em solos cauliníticos e desenvolvidos de sedimentos Terciários do grupo Barreiras e formações correlatas.

Os horizontes que apresentam o caráter coeso ou “horizontes coesos” apresentam textura franco-argilo-arenosa ou mais fina, sendo o grau de coesão proporcional ao aumento do teor de argila. Tem coloração geralmente bruno-amarelada, tendendo muitas vezes para cores mais pálidas, bruno-amarelada claro, bruno claro acinzentado ou bruno com matiz 10YR, valores 5 e 6 e cromas variando de 3 a 6 . Nos perfis mais argilosos e de cores mais pálidas, há a presença de mosqueado pequeno bruno forte, ao redor de poros e canais de raízes, refletindo a baixa aeração desses horizontes durante o período chuvoso (Ribeiro, M., 2001).

Em condições naturais a densidade média do horizonte coeso situa-se na faixa de 1,5 a $1,8 \mathrm{~g} \mathrm{~cm}^{-3}$, sendo que a expressão máxima da coesão é observada no material seco e em geral ocorre nos solos mais argilosos (Araújo Filho et al., 2001).

Com base nos critérios de identificações já existente do caráter coeso Ribeiro, $\mathrm{M}$. (2001) propôs a seguinte reformulação para a definição do termo coeso: deve ser usado para distinguir horizontes subsuperficiais adensados, de textura média, argilosa ou muito argilosa, muito resistente à penetração da faca, do martelo pedológico ou trado, sem uma organização estrutural visível, geralmente maciço moderadamente coeso a coeso, com consistência a seco, muito dura a extremamente dura, passando a friável ou firme, quando úmido, não apresentando a quebradicidade dos fragipãs, mas sim uma lenta deformação, quando submetidos à compressão. Em condições naturais, estes horizontes são encontrados entre 0,3 a 0,7 m, correspondendo normalmente ao horizonte BA, podendo se prolongar até o Bw1, ou Bt1, apresentando densidade do solo mais elevada que a dos horizontes sobrejacentes e subjacentes. Nos solos com B textural este adensamento pode atingir profundidades maiores.

Enquanto outros atributos que também conferem alta resistência ao solo, como fragipãs e duripãs, apresentam-se bem definidos e constituem horizontes diagnósticos no Sistema Brasileiro de Classificação de Solos (Embrapa, 1999), utilizados como características diferenciais no $4^{\underline{0}}$ nível categórico, o termo “coeso" é utilizado no $3^{0}$ 
nível, sem nenhuma definição como atributo diagnóstico, dando assim margem a interpretações diversas por técnicos menos familiarizados com o assunto.

\subsection{Ocorrência dos solos com horizontes coesos}

A ocorrência dos solos coesos, no Brasil, está relacionada com a Formação Barreiras (Grupo Barreiras), a qual está geologicamente relacionada com os depósitos sedimentares, derivados de materiais argilosos, argilo-arenosos e arenosos do período Terciário, que constituem a unidade geomorfológica dos Tabuleiros Costeiros (Figura 1). Os solos sob esta formação estão restritos à zona úmida costeira do litoral oriental das regiões Norte, Nordeste e Sudeste, sob climas de estações secas e úmidas bem definidas (Jacomine, 2001; Giarola \& Silva, 2002).

Os tabuleiros são formas topográficas de terreno que se assemelham a planalto, terminando geralmente de forma abrupta (Guerra, 1978). No nordeste brasileiro os tabuleiros (termo regional utilizado para designar a porção mais plana da paisagem) aparecem de modo geral em toda a costa (Figura 1), apresentando paisagem de topografia plana, sedimentar e de baixa altitude, os quais ocupam apenas na região nordeste uma área de 10.000.000 ha, correspondendo a aproximadamente 16\% da área total dos Estados da Bahia, Sergipe, Alagoas, Paraíba, Rio Grande do Norte, Pernambuco e Ceará (Souza et al., 2001).

De acordo com Ribeiro (1996) os tabuleiros são formações morfopedolitológicas, localizadas em áreas planas a subplanas, apresentando altitudes variáveis que, geralmente, não ultrapassam os 300 metros, porém é comum encontrar altitudes entre 200 e 250 m, podendo chegar até próximas ao nível do mar como é o caso do Sul da Bahia. Estas formações, do ponto de vista geológico, são constituídas por sedimentos detríticos de Idade Tércio-Quaternária, os quais são chamadas indistintamente de Grupo Barreiras.

Apesar da extensa área ocupada pelos Tabuleiros Costeiros os solos que constituem essa unidade geomorfológica apresentam similaridades nas suas características pedológicas. Segundo UFV (1984), isso se deve à natureza 
essencialmente caulinítica e quartzosa dos seus sedimentos, que, por serem bastante estáveis, não sofreram modificações de vulto com a pedogênese posterior, onde as diferenças tendem a ser determinadas pela granulometria, pelo grau de manifestação da coesão e pela drenagem do solo (Moreau, 2001).

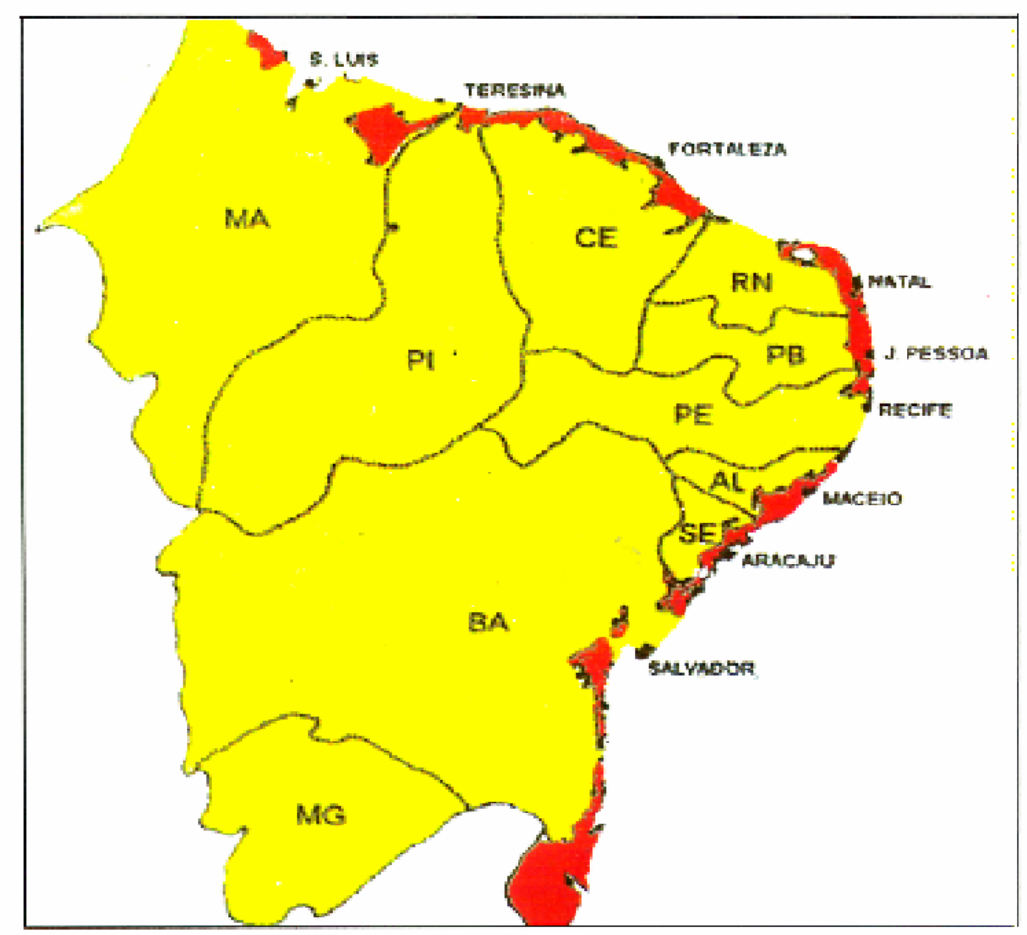

Figura 1 - Faixa dos Tabuleiros Costeiros (em vermelho) na região nordeste do Brasil: área total $=98.503 \mathrm{~km}^{2}$, correspondendo a 5,92\% da área total da região (adaptado de Silva et al., 1993)

Os antigos Latossolos Amarelos, Podzólicos Amarelos, Areia Quartzosa e em menor proporção os Podzóis são reconhecidos como os solos de maior expressão geográfica, em termos de extensão, sobre os tabuleiros (Ribeiro, 1996; Ribeiro, L., 2001; Moreau, 2001), desses, somente a classe da Areia Quartzosa não apresenta registro da ocorrência do caráter coeso. Estima-se que no Brasil, as áreas de Latossolos e Podzólicos e outros solos que são provenientes de sedimentos do tipo Barreiras ou similares, atinjam uma extensão de $200.000 \mathrm{~km}^{2}$. 
Contudo, ainda não se sabe ao certo qual fator responsável ou os fatores responsáveis pela ocorrência ou não dos solos com horizontes coesos.

\subsection{Identificação do caráter coeso}

Os primeiros estudos a observarem o caráter coeso nos solos brasileiros foram realizados na década de 50, intensificando-se a partir de 1980 (Jacomine, 1996). Nesse período, o caráter coeso não era inserido na classificação do solo, ou seja, era citado apenas na caracterização da consistência observada no campo.

Apesar do avanço no estudo do comportamento dos horizontes coesos, a identificação desse caráter continua sendo feita somente de forma qualitativa, no campo, já que a observação de um perfil de solo seco, é fundamental para caracterizar a ausência de estrutura e, ainda, testar o comportamento de pequenos fragmentos do solo seco, quando imersos em água. Contudo a utilização de parâmetros quantitativos que comprovem a coesão desses solos é de extrema importância para a compreensão do seu comportamento, pois a análise qualitativa dificulta a identificação do horizonte coeso com base em critérios seguros, que permitam a extensão de seu uso em todo país, como também, o uso de algumas medidas pode ser arbitrário e baseado na experiência.

Dentre as propostas mais recentes utilizadas na identificação do caráter coeso, pode-se citar: a alta resistência à penetração do martelo pedológico ou trado; ausência de uma organização estrutural visível, geralmente maciça moderadamente coeso a coeso (a qual esboroa-se rapidamente quando imerso em água); consistência úmida variando de friável a firme; densidade do solo mais elevada que os horizontes subjacentes; saturação por base baixa $\left(\mathrm{V}<50 \%\right.$ ); teor de $\mathrm{Fe}_{2} \mathrm{O}_{3}$ (pelo $\mathrm{H}_{2} \mathrm{SO}_{4}$ ) menor que $80 \mathrm{~g} \mathrm{~kg}^{-1}$ e o Ki igual a 1,7 ou maior (Embrapa, 1999).

Muitos estudos, com o intuito de encontrar medidas para identificação dos horizontes coesos, têm testado a eficiência dos seguintes atributos: densidade do solo, porosidade total, macro e microporos, argila dispersa em água, fracionamento de areia, resistência do solo à penetração, condutividade hidráulica e curva de retenção de água 
no solo (Santos, 1992; Souza, 1996; Cintra \& Libardi, 1998; Silva et al., 1998; Giarola et al., 2003).

Santana (2002), tentando definir com maior clareza, parâmetros que melhor caracterizem a camada coesa e a sua localização no perfil testou a resistência do solo à penetração, a macroporosidade e a densidade do solo, como atributos que permitem detectar a presença de coesão e em que profundidade ela ocorre. A densidade do solo não foi considerada um bom atributo, devido sofrer interferência da granulometria do solo na manifestação dos seus valores, como também, devido à observação de resultados elevados em solos arenosos não coesos, o que representa uma dificuldade na utilização isolada desse atributo. A condutividade hidráulica saturada se revelou um atributo bastante adequado para avaliar a coesão, reduzindo drasticamente seu valor nos horizontes coesos, no entanto, devido à dificuldade na sua medição e à correlação positiva com os macroporos, foi reforçada a indicação desse último atributo, já que o mesmo é de fácil medição. A resistência à penetração apresentou o melhor comportamento, tendo como limitação a necessidade de sua avaliação em ampla faixa de umidade do solo, para que seja estabelecido o ponto crítico em que a coesão passa a se manifestar.

A utilização da resistência à penetração como um atributo quantitativo para ser utilizado na identificação do horizonte com caráter coeso também foi sugerido por Giarola et al. (2001) e Souza et al. (2001), tendo em vista que consiste de uma medida eficiente para a caracterização do comportamento coeso e por se tratar de um método de fácil obtenção no campo.

No entanto, os valores de RP já vêm sendo utilizados na identificação dos solos hardsetting - solos australianos que apresentam comportamento similar aos "solos coesos” ou “solos com horizontes coesos” encontrados no Brasil (Giarola \& Silva, 2002) - que estabelece valores de RP igual a $2 \mathrm{MPa}$, ou superiores, $(\psi=-100 \mathrm{kPa})$ como sendo suficientes para impedir severamente o crescimento ou a emergência das plântulas (Ley et al., 1995; Mullins et al., 1992).

Com o objetivo de elaborar uma primeira proposta de classes ou graus de coesão para os horizontes coesos, foi construído e analisado um banco de dados dos solos 
localizados nos Tabuleiros Costeiros dos Estados da Bahia, Sergipe e Alagoas, sendo selecionados valores de resistência do solo à penetração (RP), macroporosidade, condutividade hidráulica saturada, densidade do solo, porosidade total e microporos dos horizontes $\mathrm{AB}$ e BA, devido expressarem melhor coesão nas três classes de solos típicos dos Tabuleiros Costeiros: Latossolo Amarelo, Argissolo Amarelo e Argissolo Acinzentado (Souza et al., 2003). Para os seis atributos analisados foram estabelecidos classes de coesão com grau baixo, médio e alto. As medidas de RP para um potencial $(\psi)$ de -100 kPa apresentaram os seguintes valores: baixa - <2,6 MPa, média - 3,0 a 3,6 MPa e alta - 4,7 MPa para o Latossolo e Argissolo Amarelo, já para os Argissolos Acinzentados os limites estabelecidos foram inferiores. No entanto, os valores de RP não apresentaram correlação com nenhum outro atributo analisado.

Outra medida utilizada para quantificar o caráter coeso é a resistência tênsil (RT) dos agregados do solo (Dexter \& Kroesbergen, 1985; Ley et al., 1989; Giarola et al., 2003), que é definida como o estresse, ou força por unidade de área, requerida para que o solo se rompa mediante a aplicação de uma tensão (Dexter \& Watts, 2000). Esta pode ser determinada por teste simples, e pode medir uma grande variação de tamanho de agregados, sendo um indicador muito sensível das condições do solo (Dexter \& Kroesbergen, 1985). Giarola et al. (2003) encontraram diferenças significativas de RT entre solo coeso (hardsetting) e não coeso (não hardsetting).

A similaridade existente entre os solos hardsettings e os coesos pode contribuir para o melhor entendimento e o estabelecimento de parâmetros mais confiáveis para a identificação e classificação dos solos coesos, já que os estudos sobre o atributo hardsetting vêm sendo realizados de longa data e além dos parâmetros morfológicos, alguns parâmetros quantitativos já são utilizados na sua identificação, como por exemplo:

i) o solo hardsetting quando seco ao ar, tipicamente apresenta uma resistência tênsil $\geq 90 \mathrm{kPa} \mathrm{m}^{-2}$ (Mullins, 1997 e Mullins, 1999);

ii) conteúdo de matéria orgânica inferior a 2\% (Mullins, 1997).

De acordo com Souza et al. (2003), a determinação de indicadores que identifiquem a presença ou ausência do horizonte coeso permite não apenas o 
estabelecimento de graus de coesão, como melhora a orientação das intervenções de uso e manejo nesses solos, minimizando os problemas de aprofundamento dos sistemas

radicular e da dinâmica da água no perfil, visando assim melhorar a produtividade e aumentar a longevidade das culturas neles implantadas.

\subsection{Gênese dos solos com horizontes coesos}

A gênese dos horizontes coesos ainda é assunto polêmico, podendo estar associada a vários processos simultâneos, como por exemplo: agrupamento de partículas de argila face a face; perda do plasma argiloso da camada superficial para as subjacentes (argiluviação); presença de compostos orgânicos pouco polimerizados; presença de sílica secundária, ferro e alumínio, dispersos nos microporos; adensamento resultante da alteração da estrutura do solo pela alternância de ciclos de umedecimento e secagem; contribuição da areia fina (UFV, 1984; Ribeiro, 1986; Ponte \& Ribeiro, 1990; Jacomine, 1996; Ferreira et al., 1999a; Araújo Filho et al., 2001; 2002; Rezende et al., 2002).

Ferreira et al. (1999a), estudando a mineralogia da fração de um Latossolo Amarelo coeso pertencente ao Grupo Barreiras, caulinítico, mostraram que esses solos apresentam a distribuição dos grãos de quartzo (material grosseiro) em relação ao plasma (micromassa) do tipo porfirogrânica, isto é, os grãos estão envoltos num plasma denso, contínuo, com pouca tendência ao desenvolvimento de microestrutura, razão do ajuste face a face das placas de caulinita, esse modelo implica no desenvolvimento de macroestrutura do tipo blocos, devendo originar Latossolos com maior densidade do solo, maior proporção de poros pequenos e menor permeabilidade. De acordo com Resende (1985), a presença de óxidos de Al e Fe (notadamente, gibbsita, goethita e hematita) e matéria orgânica, nesta ordem, tendem a desorganizar o ajuste face a face das partículas em escala microscópica.

No entanto, nenhum estudo até o momento demonstrou tal aspecto através de microscopia eletrônica e, conforme Ribeiro, L. (2001), os estudos que mostraram tal ocorrência, foram realizados na França e em solos que não apresentam as mesmas características de coesão encontradas nos horizontes coesos. Esse autor afirma ainda 
que, estudos desenvolvidos em Entre Rios e em Cruz das Almas na Bahia, através do MEV, não permitiram tal visualização.

Alguns autores atribuem a gênese dos horizontes coesos ao preenchimento dos microporos por migração de materiais como argila e matéria orgânica das partes superiores do perfil, ocasionando assim a diminuição na porosidade total do solo (Fonseca, 1986; Souza, 1996). No entanto, análises micromorfológicas desenvolvidas em horizontes coesos, mostraram que em raros casos, ocorrem cutãs de iluviação, e quando ocorrem geralmente localizam-se no topo do horizonte coeso, onde o material mineral está associado à matéria orgânica e aos poros (Ribeiro, 1991; Ribeiro, 1998).

Por isso, de acordo com Ribeiro, L. (2001), o processo de argiluviação também não explicaria a gênese dos horizontes coesos, já que os excessos de argila existente nos horizontes superficiais, geralmente são eliminados dos solos por erosão diferencial, motivo pelo qual, as águas das chuvas quando escoam superficialmente estão enriquecidas em argilas dispersas, como também, a quantidade de argila dispersa nos horizontes subsuperficiais é muito elevada para se pensar em migração vertical. Em termos de balanço eluviação/iluviação, acredita-se porém, que uma pequena parte dessas argilas possam migrar, possivelmente restringindo-se aos topos dos horizontes coesos. Segundo Meireles \& Ribeiro (1995), o entupimento dos poros estaria relacionado à sílica oriunda do ataque do quartzo pelos ácidos orgânicos e não à argila iluviada.

A gênese dos horizontes coesos, de acordo com Ribeiro (1998), está relacionada com a cobertura pedológica dos tabuleiros que se desenvolveu sobre um material de origem bastante evoluído pedogeneticamente, em virtude do período Terciário e Quaternário ter sofrido sucessivas fases de pedogênese, erosão, sedimentação, além de suas estreitas relações com a formação e alteração de couraças ferruginosas, o que torna a origem do seu material complexa. Possivelmente, e de acordo com o mesmo, este material de origem determina tipos de comportamento biogeoquímicos que levam a certas diferenciações pedogenéticas em relação a outros tipos de materiais parentais e, por conseqüência, gera solos diferenciados.

A matéria orgânica também parece desempenhar um papel importante no processo de pedogênese desses solos, pois as substâncias leves ou pouco humificadas e 
os ácidos fúlvicos, atacam quimicamente os argilominerais, promovendo a liberação da sílica, do alumínio e do ferro, destruindo ou modificando as suas estruturas e, dessa forma, provocando a desorganização das estruturas do solo (Ribeiro, 1998; Ribeiro, L., 2001). Esses processos permitiriam a acumulação da sílica proveniente da degradação das argilas, dos grãos de quartzo e de outros silicatos, preenchendo vazios ou compondo a massa do solo, e promoveria constantes modificações até a constituição dos horizontes coesos (Ribeiro, L., 2001).

Para Araújo Filho et al. (2001) essa teoria é válida, pois afirmam que tanto a sílica como outros aluminossilicatos amorfos devem atuar como agentes cimentantes temporários dos horizontes coesos, onde no período seco os processos de polimerização e precipitação fazem com que haja uma máxima expressão da coesão, os quais são desfeitos quando o solo é umedecido. Entretanto os autores ressaltam que estudos mais pormenorizados são necessários para comprovar ou descartar essas inferências.

A ocorrência das camadas coesas nos solos de Tabuleiros é atribuída mais estreitamente a processos geomórficos, ou seja, relacionados com a evolução da superfície terrestre, do que a processos pedogenéticos (Anjos, 1985). Pois, de acordo com a mesma, as propriedades associadas aos horizontes coesos já existiam quando a formação do solo foi iniciada, sendo algumas características herdadas do material de origem.

Moreau (2001) citou que o baixo teor de $\mathrm{Fe}_{2} \mathrm{O}_{3}$ poderia explicar a gênese dos horizontes coesos, já que existe uma relação inversa entre o aumento do $\mathrm{Fe}_{2} \mathrm{O}_{3}$ (extraído por ataque sulfúrico), especialmente do ferro livre e o grau de coesão do solo. Ou seja, os solos são tão mais coesos e endurecidos quanto menores os teores de $\mathrm{Fe}_{2} \mathrm{O}_{3}$.

O adensamento por dessecação resultante da alteração da estrutura do solo pela alternância de ciclos de umedecimento e secagem, seria outro processo responsável pela gênese dos horizontes coesos (Ribeiro, 1986; Ponte \& Ribeiro, 1990). Esta hipótese se baseia no pressuposto de que, durante o período seco, os agentes cimentantes seriam desidratados e a matriz argilosa consolidada a ponto de promover o adensamento, e que, durante o período úmido, os agregados seriam destruídos devido o aumento da pressão do ar no seu interior (Giarola \& Silva, 2002). De acordo com Ribeiro (1998), os 
processos de contração e expansão da massa do solo, provocados pelos ciclos de umedecimento e secagem, não explica bem o processo da coesão e nem deixa claro o motivo pelo qual a coesão não ocorre em todo o perfil e em todos os solos sobre a Formação Barreiras, e principalmente onde os teores de argila são mais elevados.

Mullins et al. (1987) explicam que os horizontes coesos (hardsetting) apesar de serem extremamente duros quando secos não apresentam o desenvolvimento de fissuras estruturais, devido à predominância da caulinita na sua mineralogia. Isso explica o fato de não serem encontradas feições pedológicas tais como, cutãs de tensão e separações plásmicas, nos horizontes coesos, em quantidades suficientes para justificar os processos de expansão e contração desses solos (Ribeiro, 1998). Assim sendo, há que se acreditar que esses processos contribuam para a formação dos horizontes coesos, mas não são os únicos responsáveis.

Outro processo seria a contribuição do fracionamento da areia no adensamento do horizonte coeso, de forma que o maior teor de areia fina e mal selecionada facilitaria o arranjo mais compacto das partículas, promovendo aumento na compacidade relativa dos horizontes com maior resistência à penetração, essas observações foram realizadas por Abrahão et al. (1998) quando estudaram a distribuição de freqüência de tamanho da fração areia em sedimentos do Grupo Barreiras.

De acordo com Souza (1996), o elevado grau de argila dispersa associado com a predominância das frações menores de areia total, pode ser a principal causa do adensamento observado nos horizontes coesos quando secos ou com baixa umidade, devido os ciclos de umedecimento e secagem, atuarem continuamente sobre essas frações, proporcionando um estado de orientação e proximidade tal, que resultaria em empacotamento das partículas, na sua coesão e no conseqüente adensamento do solo.

Há uma grande indefinição em torno da gênese dos horizontes coesos, contudo, conforme Ribeiro (1998) parece ser claro a existência de uma dependência desses solos com o material de origem e, de alguma forma, com o relevo. 


\subsection{Limitações relacionadas ao uso dos solos com horizonte coeso}

Morfologicamente as características atribuídas ao horizonte coeso, principalmente quando relacionadas à consistência no estado seco, fazem com que se tenha uma falsa idéia de compactação do solo (Demattê et al., 1996).

A presença de camadas coesas (horizontes coesos) situadas no topo do horizonte B, aliadas a má distribuição das chuvas na maioria dos solos, pode ser a principal limitação do meio físico à obtenção de elevadas produtividades das culturas, quando comparado às áreas que não apresentam camadas coesas ou déficits hídricos rigorosos. Esse processo ocorre em virtude da baixa taxa de infiltração e condutividade hidráulica, comparada a dos horizontes supra e subjacentes, não coesos (Santos, 1992). Sendo ainda considerados péssimos reservatórios de nutrientes, particularmente os horizontes subsuperficiais, devido à baixíssima CTC e a sua acidez (ácidos a fortemente ácidos), com elevados teores de alumínio trocável ao longo do perfil (Jacomine, 1996).

O elevado grau de coesão dos solos que atinge o máximo no Bt, é conseqüência de um adensamento de natureza genética, tendo sido observado com mesma intensidade em solos virgens e cultivados (Silva, 1989). Tal observação foi confirmada por Demattê et al. (1996), os quais afirmam que os dados morfológicos e granulométricos de um perfil recém desmatado não indicam alterações profundas, quando comparado com um perfil similar em área sob cultivo, ambos apresentaram coesão acentuada da consistência no estado seco.

Conforme Ribeiro (1996), os solos coesos apresentam baixos teores de matéria orgânica, horizontes superficiais arenosos, dificuldade na retenção de água e nutrientes, bem como, na circulação de água e ar no solo. Porém, em termos de granulometria o material da Formação Barreiras é bastante heterogêneo, sendo mais argiloso no Estado de Alagoas e tendendo a mais arenoso no Rio Grande do Norte (Demattê et al., 1996). Essa diferenciação se dá devido a grande variação dos ambientais deposicionais dos sedimentos que originaram a Formação Barreiras (Bigarella, 1975).

Cintra \& Libardi (1998), estudando a caracterização física de uma classe de solo dos Tabuleiros Costeiros, constataram que a presença de camadas adensadas extensas e 
próximas à superfície do solo, associadas ao regime climático característico da unidade geoambiental estudada, é uma indicação de que deverão ocorrer grandes alterações nos fatores físicos de crescimento das plantas, na redistribuição da água no solo e no sistema radicular dos citrus que, nessas circunstâncias, deverão ficar restrito a um pequeno volume de solo próximo à superfície. Conforme Demattê et al. (1996), o desenvolvimento radicular em profundidade nesses solos é pobre, decrescendo nos solos localizados em depressões. Pois embora os solos localizados sob os Tabuleiros Costeiros sejam considerados profundos, a sua profundidade efetiva é reduzida pela presença dos horizontes coesos (Portela, 2000).

Dados analíticos citados por Souza (1997) mostram que os solos coesos apresentam altos valores de densidade do solo, podendo chegar a $1,73 \mathrm{~kg} \mathrm{dm}^{-3}$, os quais associados à baixa macroporosidade (em torno de $0,10 \mathrm{~m}^{3} \mathrm{~m}^{-3}$ ) e ao alto grau de dispersão de argila em água (70 a 85\% da argila total) causam obstrução dos poros, restringindo a condutividade e a taxa de infiltração da água no solo. Esse fato faz com que a água concentre-se nos horizontes superficiais nos períodos chuvosos, favorecendo a perda por evaporação e a erosão.

Souza (1996) sugere que o elevado grau de dispersão da argila associado com a predominância das frações menores na areia total seja a principal causa do adensamento observado nos solos coesos quando secos ou com baixa umidade. A variação nos ciclos de umedecimento e secagem, podem ter atuado continuamente sobre essas frações, proporcionando a coesão e o conseqüente adensamento das partículas quando o solo está com baixa umidade.

A mineralogia das frações areia registra a presença quase absoluta de quartzo e a fração argila sendo predominantemente constituída de caulinita, com índice Ki compreendido entre 1,96 e 2,14 (Jacomine, 1996). De acordo com Ferreira et al. (1999a), os Latossolos cauliníticos apresentam estrutura em blocos, devido a caulinita apresentar um arranjo face a face de suas partículas, ocasionando com isso, maior densidade do solo, menor estabilidade de agregados em água, menor macroporosidade e menor permeabilidade (Ferreira et al., 1999b). 
Estudos realizados por Giarola et al. (2003) em solos coesos (hardsetting) no Estado da Bahia, comprovaram que o adensamento natural do solo, determinado por meio das feições micromorfológicas, resistência tênsil, resistência do solo à penetração e densidade do solo, foi o principal fator que influenciou direta e indiretamente as propriedades físicas e micromorfológicas do solo, responsáveis pela diferença observada entre o horizonte não coeso (não hardsetting) e coeso (hardsetting).

\subsection{Micromorfologia e análise de imagens no estudo dos horizontes coesos}

A micromorfologia do solo é atualmente definida como a ciência que estuda a microcontextura de materiais do solo não deformados, por métodos microscópicos (microscopia óptica e menos freqüentemente submicroscopia), comumente usando técnicas de lâminas finas (delgadas) (Mermut, 1992). O termo microcontextura é aqui utilizado como tradução para o português do termo em inglês “microfabric” (Santos, 2001).

Esta ciência é considerada uma ferramenta poderosa para refinar observações macromorfológicas, em todas as áreas de conhecimento da ciência do solo, como também de outras ciências, sendo a única técnica que permite observar os componentes do solo no seu arranjamento espacial natural, ou seja, como ocorre na natureza.

Devido a grande necessidade entre os pesquisadores de conhecer com mais detalhes o comportamento dos solos com caráter coeso, bem como, de definir parâmetros que identifiquem de forma fácil e segura a presença desse atributo no solo vários trabalhos usando técnicas micromorfológicas têm sido realizados nas áreas dos Tabuleiros Costeiros, os quais tiveram por objetivo fornecer subsídios para o entendimento da pedogênese desses solos (Santos et al., 2002; Duarte et al., 2000; Melo \& Santos, 1996), bem como, avaliar as possíveis modificações nas propriedades físicas em solos submetidos a cultivos intensos (Silva et al., 1998).

Melo \& Santos (1996) mostraram, utilizando técnicas micromorfológicas, que solos pertencentes aos Tabuleiros Costeiros e com taxonomia diferente, foram derivados do mesmo material de origem, e que a sua diferenciação, imposta pelo relevo, sugere a 
seguinte sequiência evolutiva: no início, foram formados os Latossolos, derivando, depois por translocação de argila, para os Podzólicos latossólicos e estes, por acentuadas perdas de argila e cimentação, para os Podzóis. Já Silva et al. (1998) enfatizaram que o adensamento pedogenético natural observado no horizonte coeso, pode ser acelerado sob condições de cultivo, pelo preenchimento dos poros com argila iluvial.

Duarte et al. (2000) também utilizaram técnicas micromorfológicas para estudar a mineralogia e a química dos solos pertencentes aos Tabuleiros Costeiros.

Apesar do crescente interesse que tem despertado na comunidade científica, muitos aspectos envolvendo a origem, evolução e conseqüências agrícolas dos solos coesos no Brasil, ainda permanecem incertos. Neste contexto a micromorfologia tornase extremamente necessária para aprofundar e elucidar os problemas relativos aos solos coesos, pois apesar dos aspectos qualitativos, onde procura explorar a associação entre estrutura, porosidade e contextura do solo, há também seus aspectos quantitativos, o qual procura quantificar o espaço poroso por meio da análise de imagens.

Em outros países há anos a análise de imagens vem sendo desenvolvida e aperfeiçoada por diversos micromorfologistas, os quais utilizam esta técnica para: quantificar a estrutura do espaço poroso; a distribuição dos poros; caracterizar a irregularidade, orientação, forma e tamanho dos poros, através do uso de lâminas delgadas ou blocos de solo (Bouma et al., 1977; Ringrose-Voase, 1987; Protz et al., 1987; Bouabid et al., 1992; Ringrose-Voase, 1991; Deeks et al., 1999).

De acordo com Protz et al. (1987), a aplicação da análise de imagem computadorizada para medir a porosidade e a estrutura do solo está se tornando parte integral das pesquisas de solo, principalmente as que avaliam o sistema de manejo, fornecendo bases quantitativas para descrição e levantamentos de solos, o que permite medidas exatas para componentes normalmente estimados a olho no campo (Murphy et al., 1977).

Apenas alguns trabalhos realizados nas áreas dos Tabuleiros Costeiros (Giarola et al., 2003; Santos et al., 2002; Silva et al., 1998) utilizaram a análise para quantificação do espaço poroso total, os quais concluíram que o horizonte coeso apresenta uma redução do espaço poroso em relação a outros horizontes não coesos. 


\subsection{Importância econômica}

A importância social e econômica dos Tabuleiros Costeiros é justificada pelas grandes concentrações urbanas, diversidade de exploração agrícola, ampla infraestrutura de transportes rodoviário e terminais marítimos (Rezende, 2000), como também, devido ao fato de estarem situados principalmente na faixa costeira úmida onde as precipitações pluviométricas são regulares; estão localizados próximos a grandes centros consumidores e os seus solos são normalmente profundos e se distribuem em áreas de relevo plano ou suavemente ondulado, favorecendo a mecanização agrícola (Jacomine, 2001). Dados da EMBRAPA - CPATC, mostram que, somente os Tabuleiros Costeiros dos Estados nordestinos (BA, SE, AL, PE, PB, RN, CE, PI e MA) contribuem com 26,4\% e 38,2\% do PIB gerado pelas culturas temporárias e permanente (Rezende, 2000; Cintra et al., 1997).

Cintra et al. (1997) mostram que apesar da importância dos solos de Tabuleiros Costeiros, da existência de mercado potencial e da demanda reprimida de produtos agrícolas, a atividade agropecuária tem sido, via de regra, inviabilizada em virtude das baixas produções alcançadas e da alta relação custo/benefício.

Nessas condições de produção, a presença de horizontes coesos e de regimes climáticos com longos períodos de déficit hídrico interfere diretamente nos fatores físicos que afetam o desenvolvimento das plantas, como: potencial de água no solo, aeração e resistência a penetração (Cintra et al., 1997).

A ocupação dos Tabuleiros é muito dependente das precipitações pluviais, sendo que na zona mais úmida há predomínio da cana-de-açúcar e na zona mais seca de pecuária extensiva e semi-intensiva, onde as atividades agrícolas são limitadas em médias e pequenas propriedades. A agricultura é diversificada, podendo encontrar cultivos de subsistência, fruteiras e essências florestais, sendo que essas espécies geralmente apresentam baixo vigor vegetativo e baixas produções, comparativamente aos mesmos cultivos realizados em outras unidades da paisagem, indicando uma relação fortemente influenciada pela baixa fertilidade natural, acidez elevada e pela estrutura dominante dos horizontes coesos. Estes fatores ressaltam a importância do estudo desses solos, para a melhoria das condições agrícolas e das populações que nele reside. 


\section{IDENTIFICAÇÃO E CARACTERIZAÇÃO DE SOLOS COESOS NO ESTADO DO CEARÁ}

\section{Resumo}

Dada a grande importância dos solos coesos derivados de sedimentos da Formação Barreiras e sua extensa área ocupada no nordeste brasileiro, este trabalho teve como objetivo identificar e caracterizar a ocorrência de solos coesos nos Tabuleiros Costeiros no Estado do Ceará. O estudo foi realizado em três perfis de solos, sendo dois Argissolos coesos e um Argissolo não coeso, nos quais foram observadas as características morfológicas e determinadas às propriedades físicas, químicas e mineralógicas para a identificação e comprovação do(s) horizonte(s) coeso(s). Os resultados comprovaram a hipótese de ocorrência de solos coesos no Estado do Ceará e a semelhança destes com solos coesos estudados em outros Estados brasileiros.

\section{IDENTIFICATION AND CHARACTERIZATION OF HARDSETTING SOILS IN CEARA STATE - BRAZIL}

\section{Summary}

Given the importance of the hardsetting soils derived form Barreiras Formation sediments, and the extensive area occupied by them in the Brazilian Northeast region, the objective of this paper was to identify and characterize the occurrence of hardsetting soils in Coastal Tablelands of Ceara State. The study was carried out in three soil 
profiles: two hardsetting Argisols and one non-hardsetting Argisol, in which the morphological characteristics, and physical, chemical and mineralogical properties were assessed to confirm the presence of hardsetting horizons. The results validated the hypothesis of occurrence of hardsetting soils in Ceara State and the similarities of these with other hardsetting soils studied in other Brazilian States.

\subsection{Introdução}

O termo coeso tem sido utilizado no Brasil para designar horizontes minerais subsuperficiais do solo que apresentam aumento acentuado na coesão entre as suas partículas, tornando-se duro, muito duro ou até extremamente duro quando seco e friável quando úmido (Jacomine, 1996). Os solos com esse comportamento são conhecidos no Brasil como "solos coesos” ou "solos com horizontes coesos".

O caráter coeso foi incorporado ao atual Sistema Brasileiro de Classificação de Solos como característica diagnóstica, atribuída à classe dos Latossolos Amarelos (EMBRAPA, 1999). Embora o sistema brasileiro de classificação considere o termo “coeso” apenas para a classe dos Latossolos Amarelos, há registro de ocorrência desse comportamento em Argissolos Amarelos e Argissolos Acinzentados (Jacomine, 2001).

Segundo alguns pesquisadores, o caráter coeso encontra-se, em condições naturais, principalmente nos horizontes transicionais $\mathrm{AB}$ e/ou $\mathrm{BA}$, podendo atingir o $\mathrm{Bw}$ ou Bt, sua textura varia de média a argilosa ou muito argilosa, ocorre entre 0,30 a 0,70 m de profundidade ou mais em Argissolos (Jacomine, 1996; Ribeiro, M., 2001). O uso agrícola desses solos causa mudança na morfologia dos horizontes superficiais (A e $A B$ ) com o desenvolvimento de um horizonte Ap, que pode apresentar sensível perda de estrutura (Silva et al., 1998; Ribeiro, L., 2001).

A ocorrência dos horizontes coesos é atribuída a processos geomórficos (Anjos, 1985), ou seja, iniciados com a formação do solo. Entretanto, outros autores sugerem que este comportamento advém da presença de agentes cimentantes, os quais causariam cimentações temporárias (Ribeiro, M., 2001; Araújo Filho et al., 2001) que se desfazem 
quando o solo é umedecido. Outro processo seria a obstrução dos microporos por migração de materiais finos para as partes inferiores do solo (Ribeiro, M., 2001; Giarola \& Silva, 2002), como também o ajuste face a face das argilas, resultando em um aumento da densidade do solo (Ferreira et al., 1999a,b).

Dos problemas relacionados ao caráter coeso pode-se citar a elevada resistência à penetração do solo quando seco, que afeta: i) o desenvolvimento radicular das plantas, ii) o teor de água disponível e iii) a aeração e a absorção de nutrientes, constituindo um inibidor físico que pode influenciar negativamente a produção agrícola (Rezende, 2000; Cintra et al., 1997). A baixa disponibilidade de nutrientes desses solos associada à alta saturação por alumínio e à alta acidez ativa e trocável constitui também um inibidor químico, dificultando além do desenvolvimento radicular a atividade microbiana do solo (Rezende, 2000; Souza, 1997).

Em virtude da ocorrência de solos coesos em diversas áreas do território brasileiro (Jacomine, 2001) e dos sérios problemas impostos na produção agrícola, estudos vêm sendo realizados com o intuito de elucidar este comportamento, o qual está geologicamente relacionado com os depósitos sedimentares, derivados de materiais argilosos, argilo-arenosos e arenosos da Formação Barreiras (período Terciário), que constituem a unidade geomorfológica dos Tabuleiros Costeiros.

Grandes áreas produtoras de alimentos estão localizadas nos Tabuleiros Costeiros, os quais ocupam na região nordeste uma área estimada de 10.000.000 ha, o que corresponde a aproximadamente 16\% da área total dos Estados da Bahia, Sergipe, Alagoas, Paraíba, Rio Grande do Norte, Pernambuco e Ceará (Souza et al., 2001). A produção dessa área responde por aproximadamente 26,4\% do PIB gerado pelas culturas temporárias e 38,2\% do PIB gerado pelas culturas permanentes na região nordeste (Cintra et al., 1997).

Apesar dos estudos de identificação dos solos coesos terem sido iniciados desde da metade da década de 50 e intensificados a partir de 1980, ainda há dificuldade na distinção entre solos coesos e não coesos, principalmente em condições de campo quando a identificação inicial é feita por pedólogos, através da análise morfológica do 
perfil, sendo necessária à observação de uma trincheira com solo seco para examinar a consistência dura a extremamente dura.

Este procedimento dificulta a identificação do caráter coeso com base em critérios seguros, que permitam a extensão de seu uso às demais regiões do país (Giarola et al., 2001), já que para isso são utilizados parâmetros qualitativos sob condições de campo.

Pode-se ressaltar que as propostas mais recentes que são utilizadas na identificação para o caráter coeso, não diferem muito das definições citadas anteriormente, entretanto, é acrescentada a alta resistência à penetração do martelo pedológico ou trado, e a ausência de uma organização estrutural visível, geralmente maciço moderadamente coeso a coeso (a qual esboroa-se rapidamente quando imerso em água), com consistência úmida variando de friável a firme, com densidade do solo mais elevada que os horizontes subjacentes, saturação por base baixa $(\mathrm{V}<50 \%)$, teor de $\mathrm{Fe}_{2} \mathrm{O}_{3}$ (pelo $\mathrm{H}_{2} \mathrm{SO}_{4}$ ) menor que $80 \mathrm{~g} \mathrm{~kg}^{-1}$ e o $\mathrm{Ki}$ igual a 1,7 ou maior, isto é, predominância de solos cauliníticos (EMBRAPA, 1999).

Dentre os Estados da região nordeste que possuem uma extensa área litorânea ocupada pelos tabuleiros está o Ceará (Rezende, 2000), com mais de $10.000 \mathrm{Km}^{2}$ de solos derivados da Formação Barreiras e que se enquadram dentro do contexto de solos coesos (Jacomine et al., 1973). Sua importância social e econômica é justificada pelas grandes concentrações urbanas e pela grande exploração agrícola.

Apesar de levantamentos de solos no Ceará já terem constatado características morfológicas semelhantes aos horizontes coesos (Melo, 1968; Jacomine et al., 1973), o Estado ainda não dispõe de estudos referentes a esse assunto. No entanto, Ramos \& Oliveira (1993) citam problemas de natureza química e física do solo (impedimento à drenagem e compactação), os quais são decorrentes de características naturais ou devido ao manejo inadequado do solo. Com base nessas informações estabeleceu-se a hipótese de que existem solos originados de sedimentos da Formação Barreiras no Estado do Ceará que apresentam horizonte coeso (endurecido), com limitações físicas e químicas. 
O objetivo deste trabalho foi identificar e caracterizar, por meio de parâmetros morfológicos, físicos, químicos e mineralógicos, a ocorrência de solos coesos nos Tabuleiros Costeiros do Estado do Ceará.

\subsection{Material e Métodos}

O estudo foi realizado em duas áreas localizadas no Estado do Ceará, escolhidas de acordo com informações contidas no Mapa de Solos e no Levantamento Exploratório - Reconhecimento (Jacomine et al., 1973) e também baseado em informações pessoais de pedólogos que trabalharam nos Levantamento de Solos da região.

A escolha da primeira área foi feita com base nos perfis 32 e 33, os quais apresentavam características pertinentes ao caráter coeso (Jacomine et al., 1973), ambos localizados na cidade de Camocim, litoral noroeste do CE. O perfil 1 (P1), corresponde a um Argissolo Amarelo Distrófico plíntico coeso em área sob mata, representativo da associação PV7, que abrange dentre as áreas de Tabuleiros Costeiros mais de $6.000 \mathrm{Km}^{2}$ do Estado do Ceará. Os solos dessa associação são derivados de sedimentos Terciários (Plioceno - Mioceno) não consolidados arenosos e argilo-arenosos da Formação Barreiras.

Devido à extensão dos tabuleiros no litoral cearense e a busca de outros solos que comprovassem o comportamento coeso, procurou-se colher informações de pedólogos que já haviam observado esse comportamento em outras áreas. Com base nesses dados, foram abertas quatro trincheiras em área cultivada com cajueiro, pertencente à Estação Experimental da EMBRAPA/CNPAT na cidade de Pacajus, litoral nordeste do CE, sendo todos os perfis de solo classificados como Argissolo Acinzentado coeso. Devido à homogeneidade dos mesmos optou-se por trabalhar com apenas um perfil, o qual foi denominado de P2.

Para efeito de comparação quanto à coesão, utilizou-se um perfil de solo (P3) classificado como Argissolo Amarelo não coeso, localizado em área sob mata e situado próximo ao P2. Ambos perfis são provenientes de sedimentos arenosos essencialmente 
quartzosos da Formação Barreiras e representativos da associação AQd4, a qual abrange $3.400 \mathrm{~km}^{2}$ dos Tabuleiros Costeiros no Ceará.

A descrição morfológica e a determinação dos horizontes foram realizadas conforme definições descritas em Lemos \& Santos (1996) e Jacomine (1996). Foram coletadas amostras dos diferentes horizontes para a caracterização física, química e mineralógica. Para determinação da análise granulométrica tomou-se como base a metodologia proposta por Gee \& Bauder (1986).

Os elementos químicos $\mathrm{Ca}^{2+}, \mathrm{Mg}^{2+}$ e $\mathrm{Al}^{3+}$ foram extraídos com solução de $\mathrm{KCl} 1$ N. A extração de $\mathrm{P}$ e $\mathrm{Na}^{+}$foi realizada com solução de $\mathrm{H}_{2} \mathrm{SO}_{4} 0,025 \mathrm{~N}+\mathrm{HCl} 0,05 \mathrm{~N}$. A determinação da $\mathrm{H}+\mathrm{Al}^{3+}$ foi feita com solução de acetato de cálcio $1 \mathrm{~N}$ a pH 7,0. O pH foi determinado em água, $\mathrm{KCl} 1 \mathrm{~N}$ e $\mathrm{CaCl}_{2}$ 0,01 $\mathrm{M}$ na proporção 1:2,5. Os valores de matéria orgânica foram calculados com base nos teores de carbono orgânico, determinado por titulação com sulfato ferroso amoniacal a $0,1 \mathrm{~N}$. Todas as análises químicas foram realizadas seguindo metodologia da EMBRAPA (1997).

Para a extração dos óxidos de Al, Fe, Ti, Si e Mn, utilizou-se 1g de solo (peneira de 0,5 mm), transferido para erlenmeyer de 500ml com $20 \mathrm{ml} \mathrm{H}_{2} \mathrm{SO}_{4}$ 1:1 e colocado para ferver durante 30 segundos. O Al foi determinado por titulação, o Fe e Mn por espectrofotometria por absorção atômica e o Ti por colorimetria. O Si foi solubilizado por ataque alcalino com $\mathrm{NaOH}$ a $30 \%$, durante 1 minuto. Posteriormente, a solução com silicato solúvel foi colocada em tubo de ensaio com $5 \mathrm{ml}$ de $\mathrm{H}_{2} \mathrm{SO}_{4}$ concentrado e $10 \mathrm{ml}$ de $\mathrm{HNO}_{3}$ concentrado, para precipitação e determinada por gravimetria (Raij \& Valadares, 1979).

Para a determinação da mineralogia da fração argila, foram utilizadas lâminas em suspensão, aleatoriamente orientadas, segundo a técnica sugerida por Jackson (1979). As amostras foram submetidas à pré-tratamento para remoção da matéria orgânica (com $\mathrm{H}_{2} \mathrm{O}_{2}$ em placa aquecida a $70{ }^{\circ} \mathrm{C}$ ) e óxidos livres (citrato + ditionito + bicarbonato). Os difratogramas foram obtidos através de difratômetro de raios-x (DRX) Philips PW 3710, com goniômetro vertical controlado por computador com monocromador de grafite, radiação de cobre $(\mathrm{CuK} \alpha)$, potencial de $40 \mathrm{kV}$ e corrente de $40 \mathrm{~mA}$, sendo as lâminas analisadas a uma amplitude 3 a $65^{\circ} 2 \theta$ e velocidade do goniômetro de $0,02^{\circ} 2 \theta / \mathrm{s}$. 
A umidade do solo foi determinada por meio de TDR (Time Domain Reflectometry) modelo Theta Probe tipo ML2x fabricado pela Delta-T Devices, com comprimento das hastes de $60 \mathrm{~mm}$, o qual mede a constante dielétrica do solo que é proporcional à quantidade de água presente no mesmo. Para as determinações da umidade do solo, as hastes do TDR foram inseridas na parede do perfil próximo aos pontos de medida da RP.

Para medir a RP utilizou-se um penetrômetro cônico modelo Soiltest S-310, com diâmetro da base do cone de $4 \mathrm{~mm}$ e comprimento da haste de $40 \mathrm{~mm}$. As leituras de RP foram feitas somente no horizonte Bt1 coeso do P2, devido a sua descrição morfológica indicar uma coesão mais expressiva.

Para a determinação da curva de RP em diferentes conteúdos de água no solo, cada horizonte do P2 (área sob cultivo) foi dividido em duas partes, sendo a primeira determinação feita na parte da manhã, onde o solo apresentava consistência friável e a segunda determinação realizada na parte da tarde, quando o horizonte coeso (Bt1) apresentava consistência mais endurecida, devido ao secamento. Em cada uma das etapas foram realizadas oito leituras de RP e uma de umidade. Essa determinação foi feita no dia 11/06/2002, quando já havia encerrado a estação chuvosa na região.

\subsection{Resultados e Discussão}

Os perfis estudados apresentam a mesma seqüência de horizontes (A, E e B), sendo muito profundos (Tabela 1). Observou-se no perfil 1 a presença de um horizonte intermediário A/Oo rico em matéria orgânica, constituída por restos de vegetais pouco decompostos. Os horizontes E foram caracterizados pela ocorrência da cor seca mais clara do que nos horizontes sobrejacentes, indicando tratar-se de horizontes eluviais. Já a camada coesa caracterizou-se por ocorrer no horizonte pedogenético Bt.

Deve-se ressaltar que as cores encontradas no horizonte Bt1 coeso do Argissolo Acinzentado (10 YR 7/1 (seca) e 7/2 (úmida)), não foram descritas em outros solos coesos dos tabuleiros, sugerindo a abrangência da classe de cores. 
Tabela 1. Características morfológicas de dois perfis de solos coesos e um não coeso, localizados no Estado do Ceará

\begin{tabular}{|c|c|c|c|c|c|c|}
\hline \multirow[t]{2}{*}{ Horiz. } & \multirow[t]{2}{*}{ Prof. } & \multicolumn{2}{|c|}{ Cor } & \multirow[t]{2}{*}{ Estrutura $^{1}$} & \multicolumn{2}{|c|}{ Consistência } \\
\hline & & Seca & Úmida & & Seca $^{2}$ & Úmida \\
\hline \multicolumn{7}{|c|}{ Munsell } \\
\hline \multicolumn{7}{|c|}{ Argissolo Amarelo coeso sob mata - (P1) } \\
\hline $\mathrm{A} / \mathrm{O}_{\mathrm{o}}$ & $0,0-0,05$ & - & 10YR 4/2 & Fraca peq./ méd. granular e grãos simples & & \\
\hline A2 & $0,05-0,17$ & 10YR 5/3 & $10 \mathrm{YR} 4 / 3$ & Grãos simples, fraca, peq. bl. subang. & Macia & Friável \\
\hline $\mathrm{AE}$ & $0,17-0,40$ & 10YR 6/3 & 10YR $5 / 3$ & Maciço & Dura & Muito friável \\
\hline $\mathrm{E}$ & $0,40-0,74$ & 10YR 7/4 & 10YR 7/6 & Maciço c/ tendência à formação de blocos & Lig. Dura & Muito friável \\
\hline Bt (coeso) & $0,74-0,98$ & - & 10YR 6/6 & Maciço & Muito dura & Friável \\
\hline Btf (coeso) & $0,98-1,32$ & - & 10YR 6/6 & Fraca, peq./ méd. blocos subangulares & Dura e ext. Dura & Firme \\
\hline $\mathrm{BC}$ & $1,32-1,60$ & - & 10YR 7/6 & Maciço c/ tendência à formação de blocos & Dura & Firme \\
\hline \multicolumn{7}{|c|}{ Argissolo Acinzentado coeso sob cultivo - (P2) } \\
\hline Ap & $0,0-0,15$ & 10YR 6/2 & 10YR 5/2 & Grãos simples & Macia & Muito friável \\
\hline $\mathrm{AE}$ & $0,15-0,30$ & 10YR 6/2 & 10YR6/2 & Grãos simples & Macia & Muito friável \\
\hline E1 & $0,30-0,50$ & 10YR7/2 & 10YR $6 / 2,5$ & Grãos simples & Macia & Muito friável \\
\hline E2 & $0,50-0,97$ & 10YR $7 / 2$ & 10YR 6/2 & Grão simples, fraca, peq. bl. subang. & Macia & Muito friável \\
\hline Bt1 (coeso) & $0,97-1,27$ & 10YR 7/1 & 10YR 7/2 & Maciço c/ tendência à formação de blocos & Ext. dura & Friável/firme \\
\hline Bt2 (coeso) & $1,27-1,87$ & 10YR $7 / 1,5$ & 10YR $6,5 / 2$ & Maciço c/ tendência à formação de blocos & Muito dura & Friável/firme \\
\hline \multicolumn{7}{|c|}{ Argissolo Amarelo não coeso sob mata - (P3) } \\
\hline A & $0,0-0,20$ & $10 Y R 5 / 3$ & 10YR 4/3 & Grãos simples fraca peq. a média granular & Macia & Muito friável \\
\hline $\mathrm{AE}$ & $0,20-0,50$ & 10YR 6/3 & 10YR 5/3,5 & Grãos simples & Macia & Muito friável \\
\hline $\mathrm{E}$ & $0,50-0,92$ & 10YR $7 / 3$ & 10YR 6/5 & Grãos simples & Macia & Muito friável \\
\hline EB & $0,92-1,30$ & 10YR 7/4 & $10 Y R$ 5/5 & Grãos simples fraca, peq. bl. subang. & Macia & Muito friável \\
\hline Bt1 & $1,30-1,72$ & $10 \mathrm{YR} 6 / 6$ & 2,5 YR 5/8 & Maciço c/ tendência à formação de blocos & Macia/lig.dura & Friável/firme \\
\hline Bt2 & $1,72-1,92$ & - & 10YR 6/6 & Maciço & Macia & Friável \\
\hline
\end{tabular}

A identificação de Argissolos Amarelos e Acinzentados nos Tabuleiros Costeiros já foi feita em vários Estados (PB, PE, AL, SE e BA) (Jacomine, 1996), entretanto, somente agora a classe dos Argissolos Amarelos foi identificada no Ceará, isso se deve ao fato destes solos só recentemente passaram a constituir classe distinta entre os Argissolos, sendo anteriormente englobada dentro dos Argissolos Vermelho-Amarelos.

A consistência variando de muito dura a extremamente dura, quando seca, e friável a firme, quando úmido, nos horizontes Bt dos Argissolos, evidencia a ocorrência de horizonte coeso nos perfis P1 e P2 (Tabela 1).

Embora a consistência firme seja atribuída por alguns pesquisadores (Lindbo \& Veneman, 1993) ao caráter fragipânico, há registros de consistência friável a firme em horizontes coesos (Reunião técnica sobre solos coesos dos Tabuleiros Costeiros, 1996).

No Brasil não há estudos referentes à umidade ideal para definição da consistência úmida em condições de campo, dificultando a determinação do 
comportamento coeso. Portanto, a incorporação da consistência friável/firme na definição desse caráter poderia facilitar a identificação no campo, já que o mesmo não pode ser confundido com o caráter fragipânico, que se apresenta firme e quebradiço quando úmido (Lindbo \& Veneman, 1993).

A comparação da consistência seca do horizonte Bt coeso (P1 e P2) com o horizonte Bt não coeso (P3), comprova a alta coesão desses solos quando seco, já que ambos possuem a mesma classe textural (Tabela 2), e têm sua máxima expressão a 0,74 m de profundidade no P1 e 0,97 m no P2 (Tabela 1), estando os horizontes estudados dentro da faixa de profundidade típica da camada coesa encontrada em outros Estados (Araújo Filho et al., 2001; Reunião técnica sobre solos coesos dos Tabuleiros Costeiros, 1996).

A estrutura dos horizontes Bt coesos (P1 e P2), apresenta-se maciça com tendência a formação de blocos (Tabela 1), o que desfaz o caráter totalmente apedal desses solos. Perfis descritos pela Reunião técnica sobre solos coesos dos Tabuleiros Costeiros (1996) na Bahia, mostram solos coesos com estrutura fraca a moderada e pequena a média blocos subangulares associados com fragmentos coesos. Não sendo essa estruturação do solo favorecida pelo acúmulo de matéria orgânica, já que esse fato também ocorre em área sob cultivo, ficando evidente que alguns solos apresentam organização estrutural visível.

Estudos micromorfológicos realizados por Silva et al. (1998), observaram a existência de microagregados intergranulares em solos coesos com 25 anos de cultivo, o que comprova a tendência à formação de blocos observada no campo.

A ocorrência da estrutura maciça observada no horizonte Bt do P3 (não coeso), pode ser explicada pelo fato desse horizonte coincidir com a presença de mosqueados pequenos a médios, o que reflete maior coesão quando o solo encontra-se seco.

Os dados da composição granulométrica mostram predomínio da fração areia em todos os perfis de solo, com maiores teores nos horizontes superficiais. A classe textural franco argilo-arenosa, nos horizontes Bt coesos, coincide com o aumento proporcional dos teores de argila total (Tabela 2). 
Comparando morfologicamente os perfis 1 e 3 (Argissolos Amarelos) com outros de mesma classificação localizados no Estado da Bahia (Paiva et al., 1998; Reunião técnica sobre solos coesos dos Tabuleiros Costeiros, 1996), verifica-se grande similaridade, principalmente no horizonte Bt coeso. Contudo, a granulometria desses solos é bastante heterogênea, sendo os solos da Bahia mais argilosos, tendendo a arenosos no Ceará. Essa diferenciação se dá devido a grande variação dos ambientais deposicionais dos sedimentos que originaram a Formação Barreiras (Bigarella, 1975).

Tabela 2. Análise granulométrica de dois solos coesos e um solo não coeso, localizados no Estado do Ceará

\begin{tabular}{|c|c|c|c|c|c|c|c|c|c|}
\hline \multirow[t]{2}{*}{ Horiz. } & \multirow[t]{2}{*}{ Prof. } & \multicolumn{5}{|c|}{ Areia $^{1}$} & \multirow{2}{*}{ Silte } & \multirow{2}{*}{$\begin{array}{c}\text { Argila } \\
\text { Total }\end{array}$} & \multirow[t]{2}{*}{ Classe Textural } \\
\hline & & MG & G & $\mathrm{M}$ & $\bar{F}$ & MF & & & \\
\hline & $\mathrm{m}$ & \multicolumn{8}{|c|}{ - } \\
\hline \multicolumn{10}{|c|}{ Argissolo Amarelo coeso sob mata - (P1) } \\
\hline $\mathrm{A} / \mathrm{O}_{\mathrm{o}}$ & $0,0-0,05$ & 30 & 120 & 360 & 250 & 80 & 60 & 100 & Areia franca \\
\hline A2 & $0,05-0,17$ & 20 & 90 & 290 & 310 & 130 & 60 & 100 & Areia franca \\
\hline $\mathrm{AE}$ & $0,17-0,40$ & 20 & 100 & 320 & 260 & 80 & 60 & 160 & Franco-arenosa \\
\hline $\mathrm{E}$ & $0,40-0,74$ & 30 & 90 & 240 & 290 & 90 & 60 & 200 & Franco-arenosa \\
\hline Bt (соеso) & $0,74-0,98$ & 30 & 90 & 200 & 230 & 110 & 60 & 280 & Franco argilo-arenosa \\
\hline Btf (coeso) & $0,98-1,32$ & 30 & 80 & 170 & 180 & 80 & 80 & 380 & Argilo-arenosa \\
\hline BC & $1,32-1,60$ & 40 & 80 & 190 & 220 & 110 & 80 & 280 & Franco argilo-arenosa \\
\hline \multicolumn{10}{|c|}{ Argissolo Acinzentado coeso sob cultivo - (P2) } \\
\hline Ap & $0,0-0,15$ & 10 & 100 & 520 & 270 & 40 & 20 & 40 & Areia \\
\hline $\mathrm{AE}$ & $0,15-0,30$ & 10 & 90 & 550 & 230 & 40 & 20 & 60 & Areia \\
\hline E1 & $0,30-0,50$ & 10 & 100 & 510 & 230 & 50 & 20 & 80 & Areia \\
\hline E2 & $0,50-0,97$ & 10 & 70 & 440 & 280 & 40 & 60 & 100 & Areia franca \\
\hline Bt1 (coeso) & $0,97-1,27$ & 20 & 90 & 380 & 160 & 20 & 40 & 290 & Franco argilo-arenosa \\
\hline Bt2 (coeso) & $1,27-1,87$ & 20 & 100 & 360 & 170 & 40 & 20 & 290 & Franco argilo-arenosa \\
\hline \multicolumn{10}{|c|}{ Argissolo Amarelo não coeso sob mata - (P3) } \\
\hline A & $0,0-0,20$ & 0 & 60 & 630 & 180 & 30 & 20 & 80 & Areia \\
\hline $\mathrm{AE}$ & $0,20-0,50$ & 0 & 60 & 570 & 210 & 40 & 20 & 100 & Areia franca \\
\hline $\mathrm{E}$ & $0,50-0,92$ & 0 & 60 & 550 & 230 & 40 & 20 & 100 & Areia franca \\
\hline EB & $0,92-1,30$ & 0 & 60 & 480 & 220 & 40 & 20 & 180 & Franco-arenosa \\
\hline Bt1 & $1,30-1,72$ & 0 & 80 & 420 & 170 & 30 & 20 & 280 & Franco argilo-arenosa \\
\hline Bt2 & $1,72-1,92$ & 0 & 70 & 420 & 200 & 40 & 30 & 240 & Franco argilo-arenosa \\
\hline
\end{tabular}


Apesar da mudança textural nos sedimentos que originou os solos da Formação Barreiras, a descrição morfológica mostrou que não há diferenciação quanto ao comprometimento físico. Ou seja, estes solos apesar de apresentarem uma textura mais arenosa, mostraram-se tão duros e maciços quanto os solos argilosos da Bahia.

Demattê et al. (1996) já haviam verificado essas alterações da granulometria quando comparou solos da Formação Barreiras dos Estados de Alagoas e Rio Grande do Norte.

Estudos realizados por Mullins \& Panayiotopoulos (1984) mostraram que misturas artificiais de areia com pequenas quantidades de argila (caulinita), em torno de 2\%, são suficientes para o solo apresentar um comportamento coeso (hardsetting), já que o espaço poroso de uma matriz composta apenas por areia, dificilmente excede $50 \%$ do volume total da porosidade do solo.

Resende et al. (1992) comentam que partículas da fração areia mal selecionadas e finas favorecem o arranjamento adensado dos seus constituintes. Abrahão et al. (1998), também verificaram que a distribuição de freqüência dos tamanhos da fração areia influencia o aumento da compacidade relativa nos horizontes com maior resistência à penetração, em solos derivados de sedimentos do Grupo Barreiras.

Com base nessas informações, pode-se sugerir que a formação dos horizontes Bt coesos, no Ceará, é influenciada pela desuniformidade da composição granulométrica dos solos, já que a fração areia representa mais de $60 \%$ do total e, desta, $80 \%$ é constituída pela fração areia média a fina (Tabela 2).

Com exceção do horizonte A/Oo do P1, os níveis de M.O. são inferiores a 20 g $\mathrm{kg}^{-1}$ (Tabela 3), os quais atendem às exigências para o estabelecimento de solos hardsetting que, segundo Giarola et al. (2001), apresentam comportamento similar aos solos coesos.

Os solos apresentaram limitada disponibilidade de nutrientes, com baixos valores de soma de bases (SB), capacidade de troca de cátions (T) e fósforo (P), com alta saturação em alumínio (m). Alguns valores de m estão superiores a 50 \%, podendo indicar impedimento químico ao desenvolvimento radicular (Tabela 3). 
Os horizontes Bt coesos (P1 e P2) são distróficos, com pH fortemente ácido e T com valores inferiores a $65 \mathrm{mmol}_{\mathrm{c}} \mathrm{kg}^{-1}$, ou seja, se enquadram nas características atribuídas aos horizontes coesos (Jacomine, 1996).

Tabela 3. Características químicas de dois solos coesos e um solo não coeso, localizados no Estado do Ceará

\begin{tabular}{|c|c|c|c|c|c|c|c|c|c|}
\hline \multirow{2}{*}{ Horiz. } & \multirow[t]{2}{*}{ M.O } & \multirow[t]{2}{*}{$\mathrm{P}$} & \multirow{2}{*}{ SB } & \multirow[t]{2}{*}{$\mathrm{T}$} & \multirow{2}{*}{$\mathrm{V}$} & \multirow[t]{2}{*}{$\mathrm{m}$} & \multicolumn{3}{|c|}{ PH } \\
\hline & & & & & & & $\mathrm{H}_{2} \mathrm{O}$ & $\mathrm{KCl}$ & $\mathrm{CaCl}_{2}$ \\
\hline & $\mathrm{g} \mathrm{kg}^{-1}$ & $\mathrm{mg} \mathrm{kg}^{-1}$ & ---- n & $\mathrm{ckg}^{-1}-$ & $\overline{-a---1}$ & - & & & \\
\hline \multicolumn{10}{|c|}{ Argissolo Amarelo coeso sob mata - (P1) } \\
\hline $\mathrm{A} / \mathrm{Oo}$ & 61 & 8 & 16,2 & 106,2 & 15 & 16 & 5,1 & 4,1 & 4,3 \\
\hline A2 & 10 & 2 & 4,0 & 40,0 & 10 & 56 & 4,5 & 3,7 & 3,8 \\
\hline $\mathrm{AE}$ & 10 & 3 & 4,3 & 44,3 & 10 & 65 & 4,5 & 3,8 & 3,9 \\
\hline E & 8 & 3 & 2,8 & 30,8 & 9 & 71 & 4,6 & 3,9 & 3,9 \\
\hline Bt (coeso) & 8 & 2 & 3,0 & 33,0 & 9 & 70 & 4,5 & 3,9 & 3,9 \\
\hline Btf (coeso) & 5 & 2 & 3,6 & 37,6 & 10 & 69 & 4,3 & 3,8 & 4,0 \\
\hline $\mathrm{BC}$ & 5 & 2 & 2,9 & 34,9 & 8 & 67 & 4,4 & 3,9 & 4,0 \\
\hline \multicolumn{10}{|c|}{ Argissolo Acinzentado coeso sob cultivo - (P2) } \\
\hline Ap & 13 & 1 & 3,9 & 8,9 & 44 & 34 & 4,5 & 4,1 & 4,0 \\
\hline $\mathrm{AE}$ & 5 & 1 & 3,7 & 15,7 & 24 & 71 & 4,3 & 3,9 & 3,9 \\
\hline E1 & 5 & 1 & 14,0 & 26,0 & 54 & 36 & 3,9 & 3,8 & 3,7 \\
\hline E2 & 10 & 1 & 5,6 & 9,6 & 58 & 35 & 4,5 & 4,1 & 4,0 \\
\hline Bt1 (coeso) & 3 & 1 & 11,2 & 25,2 & 44 & 42 & 4,2 & 4,0 & 3,9 \\
\hline Bt2 (coeso) & 5 & 2 & 6,2 & 21,2 & 29 & 59 & 4,5 & 4,0 & 4,0 \\
\hline \multicolumn{10}{|c|}{ Argissolo Amarelo não coeso sob mata - (P3) } \\
\hline A & 8 & 1 & 4,2 & 24,2 & 17 & 66 & 3,9 & 3,7 & 3,7 \\
\hline $\mathrm{AE}$ & 5 & 1 & 5,6 & 23,6 & 24 & 64 & 3,8 & 3,9 & 3,7 \\
\hline E & 5 & 1 & 2,4 & 17,4 & 14 & 77 & 4,1 & 3,9 & 3,8 \\
\hline EB & 5 & 1 & 3,0 & 21,0 & 14 & 77 & 3,7 & 3,8 & 3,6 \\
\hline Bt1 & 8 & 1 & 4,2 & 19,2 & 22 & 70 & 4,1 & 3,8 & 3,7 \\
\hline Bt2 & 5 & 1 & 4,4 & 20,4 & 22 & 67 & 3,9 & 3,9 & 3,8 \\
\hline
\end{tabular}

Observa-se um incremento de $\mathrm{SiO}_{2}$ nos horizontes $\mathrm{Bt}$ coesos dos perfis 1 e 2, em relação ao horizonte $\mathrm{Bt1}$ do perfil 3 (não coeso). $\mathrm{O}$ aumento do $\mathrm{SiO}_{2}$ é maior nos horizontes coesos, apesar de ambos os perfis apresentarem teores de argila semelhantes e estarem inseridos na mesma classe textural (Tabela 4). Isso indica que este componente pode estar influenciando a coesão desses solos, contudo Moreau (2001) e Giarola et al. (2001), estudando solos no Estado da Bahia, não observaram incremento do $\mathrm{SiO}_{2}$ nos horizontes coesos. 
Tabela 4. Teores de $\mathrm{SiO}_{2}, \mathrm{Al}_{2} \mathrm{O}_{3}, \mathrm{Fe}_{2} \mathrm{O}_{3}, \mathrm{MnO}_{2}$ e $\mathrm{TiO}_{2}$ extraídos por ataque sulfúrico em dois solos coesos e um não coeso, localizados no Estado do Ceará

\begin{tabular}{|c|c|c|c|c|c|c|c|c|}
\hline Horiz. & Prof. & $\mathrm{SiO}_{2}$ & $\mathrm{Al}_{2} \mathrm{O}_{3}$ & $\mathrm{Fe}_{2} \mathrm{O}_{3}$ & $\mathrm{MnO}_{2}$ & $\mathrm{TiO}_{2}$ & $\mathrm{Ki}$ & $\mathrm{Kr}$ \\
\hline \multicolumn{9}{|c|}{$\bar{M}$} \\
\hline \multicolumn{9}{|c|}{ Argissolo Amarelo coeso sob mata - (P1) } \\
\hline $\mathrm{A} / \mathrm{O}_{\mathrm{o}}$ & $0,0-0,05$ & 2,0 & 1,87 & 0,28 & 0,001 & 0,12 & 1,82 & 1,66 \\
\hline A2 & $0,05-0,17$ & 1,8 & 2,53 & 0,25 & 0,002 & 0,18 & 1,21 & 1,14 \\
\hline $\mathrm{AE}$ & $0,17-0,40$ & 4,0 & 4,84 & 0,65 & 0,003 & 0,23 & 1,40 & 1,29 \\
\hline E & $0,40-0,74$ & 5,8 & 6,39 & 0,72 & 0,002 & 0,26 & 1,54 & 1,44 \\
\hline Bt (coeso) & 0,74-0,98 & 9,3 & 9,14 & 0,99 & 0,003 & 0,34 & 1,73 & 1,62 \\
\hline Btf (coeso) & 0,98-1,32 & 14,4 & 13,22 & 1,49 & 0,003 & 0,46 & 1,85 & 1,73 \\
\hline BC & $1,32-1,60$ & 8,9 & 10,24 & 1,17 & 0,003 & 0,39 & 1,48 & 1,38 \\
\hline \multicolumn{9}{|c|}{ Argissolo Acinzentado coeso sob cultivo - (P2) } \\
\hline Ap & $0,0-0,15$ & 1,4 & 1,54 & 0,10 & 0,003 & 0,19 & 1,55 & 1,49 \\
\hline $\mathrm{AE}$ & $0,15-0,30$ & 1,7 & 1,32 & 0,30 & 0,004 & 0,19 & 2,19 & 1,91 \\
\hline E1 & $0,30-0,50$ & 1,8 & 1,43 & 0,14 & 0,002 & 0,15 & 2,14 & 2,02 \\
\hline E2 & $0,50-0,97$ & 3,1 & 2,64 & 0,49 & 0,003 & 0,20 & 2,00 & 1,78 \\
\hline Bt1 (coeso) & $0,97-1,27$ & 10,4 & 8,48 & 0,89 & 0,003 & 0,33 & 2,09 & 1,95 \\
\hline Bt2 (coeso) & $1,27-1,87$ & 11,8 & 9,14 & 1,11 & 0,003 & 0,37 & 2,19 & 2,04 \\
\hline \multicolumn{9}{|c|}{ Argissolo Amarelo não coeso sob mata - (P3) } \\
\hline A & $0,0-0,20$ & 0,9 & 1,32 & 0,26 & 0,001 & 0,11 & 1,16 & 1,03 \\
\hline $\mathrm{AE}$ & $0,20-0,50$ & 3,2 & 2,20 & 0,51 & 0,002 & 0,11 & 2,47 & 2,15 \\
\hline E & 0,50-0,92 & 4,2 & 2,75 & 0,59 & 0,002 & 0,13 & 2,60 & 2,28 \\
\hline EB & 0,92-1,30 & 6,8 & 5,61 & 0,55 & 0,002 & 0,22 & 2,06 & 1,94 \\
\hline Bt1 & $1,30-1,72$ & 9,5 & 8,15 & 1,23 & 0,003 & 0,31 & 1,98 & 1,81 \\
\hline Bt2 & $1,72-1,92$ & 7,7 & 7,93 & 1,07 & 0,002 & 0,33 & 1,65 & 1,52 \\
\hline
\end{tabular}

Os teores de $\mathrm{Al}_{2} \mathrm{O}_{3}$ também apresentaram um incremento nos horizontes $\mathrm{Bt}$, no entanto, em termos percentuais, observa-se pouca diferença entre os solos coesos e não coesos.

Entre os horizontes de acumulação de argila, o menor teor de $\mathrm{Fe}_{2} \mathrm{O}_{3}$ encontra-se localizado no Bt1 coeso do P2, evidenciando uma relação inversa entre o teor de $\mathrm{Fe}_{2} \mathrm{O}_{3}$ e o grau de coesão, corroborando com os dados encontrados por Moreau (2001). A presença de óxidos de $\mathrm{Al}$ e Fe e a matéria orgânica tendem a desorganizar as partículas do solo em escala microscópica (Ferreira et al. 1999b), sendo que, quanto maior o teor desses constituintes maior será o grau de desorganização das partículas e, conseqüentemente, menor a coesão do solo. 
A natureza caulinítica da fração argila observada nos três perfis (Figura 1), justifica os valores da relação molecular Ki, o qual indica solos bastantes intemperizados (Tabela 4), permitindo a pedogênese dos horizontes coesos.

A predominância da caulinita na fração argila contribui para a coesão dos solos de tabuleiros, devido a sua forma laminar que possibilita o ajuste face a face das partículas do solo (Ferreira et al. 1999b).

As curvas de resistência à penetração (Figura 2a e b), permitem diferenciar os distintos graus de coesão observados ao longo do perfil. A diferenciação da RP nos horizontes dá-se em função dos valores da umidade do solo. Quando o solo está úmido os valores de RP diminuem (Figura 2a), com o secamento, observa-se um aumento da RP (Figura 2b). Vê-se que a diminuição da umidade de apenas 2\% foi suficiente para aumentar a RP de 4,7 MPa (Figura 2a) para 8,5 MPa no horizonte Bt1 coeso (Figura 2b), corroborando com os dados de RP em solos coesos na Bahia, onde foi necessária apenas uma diminuição de 5\% na umidade do solo, para a RP aumentar de 0,98 MPa para 12,76 MPa (Giarola et al., 2001). 

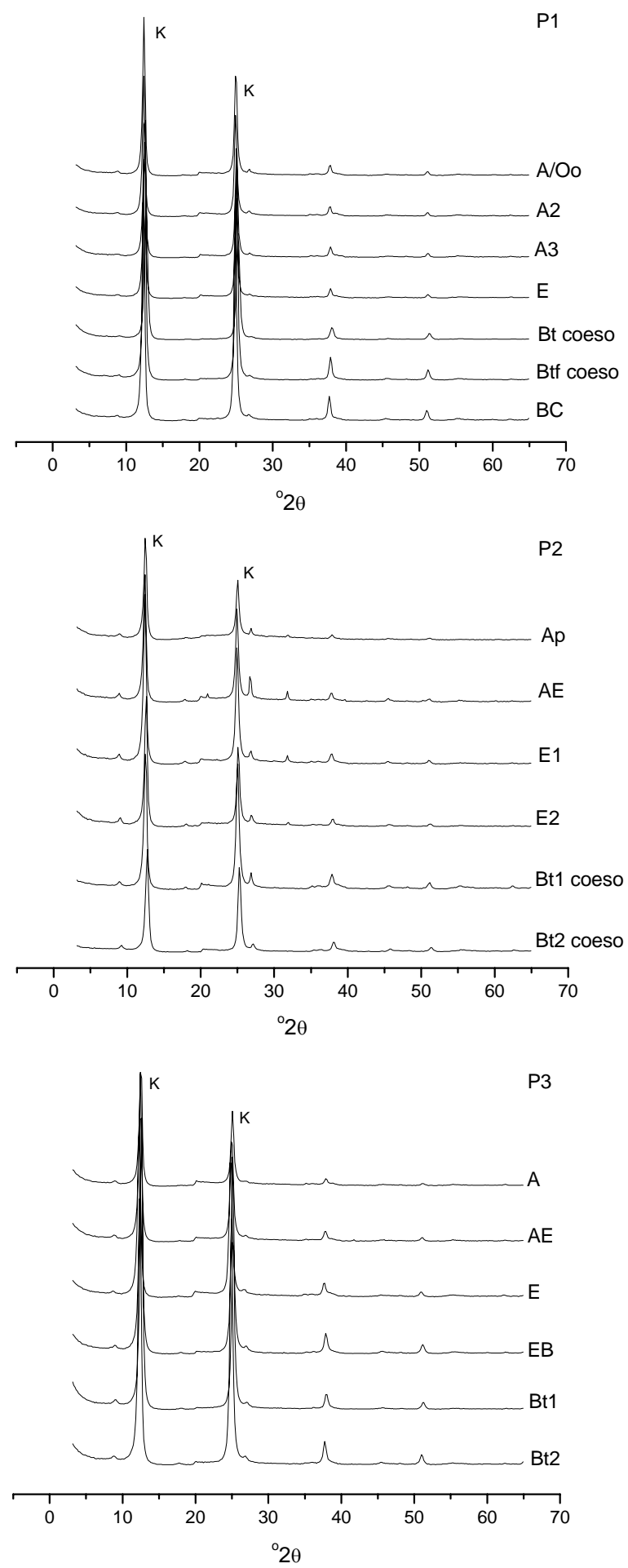

Figura 1 - Difratograma de raios-X da fração argila de três perfis de solo derivados da Formação Barreiras no Estado do Ceará. (K - caulinita) 
Esses resultados mostram que a RP pode ser utilizada como um indicador da coesão do solo, já que é uma medida bastante sensível e eficiente para a caracterização do comportamento coeso, como também, é um método de fácil obtenção no campo.

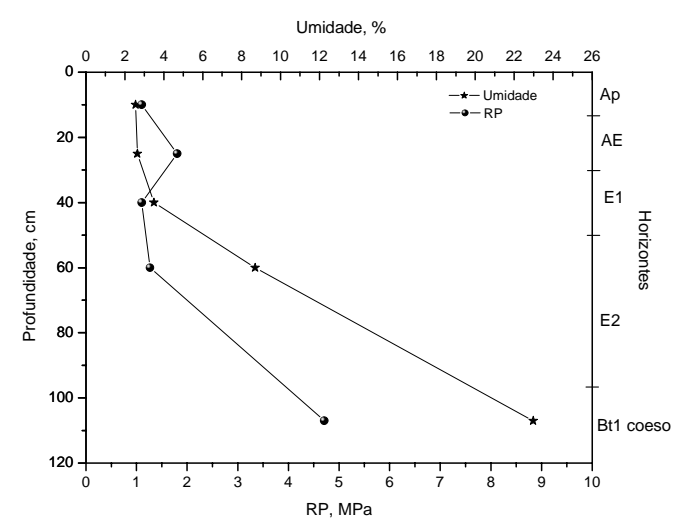

(a)

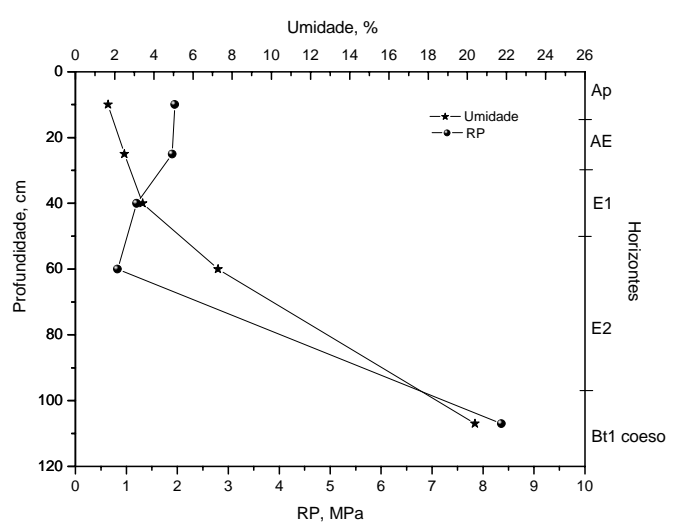

(b)

Figura 2 - Curvas de resistência à penetração (RP) e de umidade do solo de um Argissolo Acinzentado coeso (P2). a) leituras de RP e umidade realizadas em solo úmido (período da manhã) e b) leituras de RP e umidade realizadas em solo mais endurecido devido ao secamento (período da tarde)

\subsection{Conclusões}

Os resultados morfológicos, físicos e químicos comprovam a hipótese de ocorrência de solos coesos no Estado do Ceará.

A camada coesa do Argissolo Amarelo e Acinzentado no Estado do Ceará apresenta-se semelhante às camadas coesas dos solos derivados da Formação Barreiras em outros Estados brasileiros. 


\section{COMPORTAMENTO FÍSICO DE UM ARGISSOLO ACINZENTADO COESO NO ESTADO DO CEARÁ}

\section{Resumo}

Em muitas partes do mundo, estuda-se o comportamento natural de um conjunto de solos que se torna duro, muito duro ou extremamente duro, quando seco, e friável quando úmido. No Brasil os solos com esse comportamento são conhecidos como "solos coesos" ou "solos com horizontes coesos". Este trabalho teve como objetivo avaliar o comportamento de um solo com horizonte coeso, em área de Tabuleiros Costeiros no Estado do Ceará, a partir de parâmetros físicos como: resistência tênsil (RT), resistência do solo à penetração (RP), densidade (Ds) e porosidade do solo (PT). O estudo foi realizado no município de Pacajus, em um Argissolo Acinzentado Distrófico arênico coeso. Os resultados mostraram que os solos coesos do Estado do Ceará, apresentam as mesmas restrições físicas identificadas em solos coesos de outros Estados brasileiros, sendo que os valores da RT, RP e Ds, mostraram-se mais elevados no solo coeso do Ceará, confirmando a hipótese testada. 


\section{PHYSICAL BEHAVIOR OF A HARDSETTING GRAY ARGISOL IN CEARA STATE}

\section{Summary}

The natural behavior of a set of soils that becomes hard, very hard or extremely hard when dry, and friable when wet, has been studied in many parts of the world. In Brazil, the soils in which this behavior is observed are known as "hardsetting soil” or "soil with hardsetting horizon". The objective of this study was to evaluate the behavior of soils with hardsetting horizon, in Ceara State Coastal Tablelands areas, through the following physical parameters: tensile strength (RT), penetration resistance of the soil (RP), bulk density (Ds) and soil porosity (PT). The study was carried out in Pacajus,

State of Ceara, Brazil, in a hardsetting Gray Argisol. The results showed that the hardsetting soils in Ceara had the same physical restrictions identified in hardsetting soils in others Brazilian States. The RT, RP and Ds values were higher in Ceara State hardsetting soil, confirming the hypothesis tested.

\subsection{Introdução}

Solos com caráter coeso têm sido definidos como aqueles que se apresentam duros, muito duros ou até extremamente duros, quando secos, e friáveis, quando úmidos (Jacomine, 1996), sendo característicos de horizontes subsuperficiais (BA e/ou parte do Bw ou Bt) dos solos pertencentes às áreas de Tabuleiros Costeiros.

A origem dos horizontes com caráter coeso ainda não foi completamente esclarecida, porém sabe-se que ocorre de forma natural e que pode estar associada a vários processos, tais como: perda do plasma argiloso das camadas superficiais do solo para as camadas subjacentes; forte instabilidade estrutural; presença de argila dispersa, como de outros agentes químicos, nos microporos; e adensamento por dessecação proveniente da alteração da estrutura do solo pela alternância de ciclos de umedecimento e secagem (Ribeiro, 1986; Ponte \& Ribeiro, 1990). 
Mullins et al. (1987) propõem uma explicação física para solos com esse tipo de comportamento, como também indicam vários problemas agronômicos que estão associados, como: restrição ao cultivo e aumento do impedimento físico para crescimento de raízes. Outros estudos também mostram a grande influência das propriedades físicas no comportamento desses solos (Cintra \& Libardi, 1998; Giarola et al., 2003).

Um indicador físico muito sensível das condições do solo é a resistência tênsil, que é usada para avaliar a resistência dos agregados, podendo ser determinada por teste simples (Dexter \& Kroesbergen, 1985) e, ao mesmo tempo, mostra-se dependente da composição do solo, bem como do volume de agregados (Guérif, 1990). Essa resistência é definida como o estresse, ou força por unidade de área, requerida para que o solo se rompa mediante a aplicação de uma tensão (Dexter \& Watts, 2000).

A resistência do solo à penetração (RP) é outra medida física bastante utilizada para avaliar o grau de adensamento dos solos (Smith et al., 1997), já que os pãs (horizontes endurecidos) têm poucos macroporos e desenvolvem uma resistência do solo muito alta, suficiente para restringir o crescimento das raízes (Vepraskas, 1984). A RP é fortemente relacionada pelo conteúdo de água e pode mudar consideravelmente com os ciclos de umedecimento e secagem do solo (Smith et al., 1997).

Um grande desafio é avaliar qual propriedade física é mais sensível para determinar a ocorrência ou não de um solo com horizonte coeso. Giarola et al. (2003), estudando solos coesos do Estado da Bahia, concluiu que as medida de resistência tênsil, resistência do solo à penetração e densidade do solo, foram os principais fatores que influenciaram direta ou indiretamente as propriedades físicas analisadas, sendo estas, responsáveis pelas diferenças entre solos coesos e não coesos.

Diversos estudos foram realizados em áreas de solos coesos nos Estados da BA, PE, AL enfatizando a importância das propriedades físicas no comportamento desses solos (Silva et al., 1998; Cintra \& Libardi, 1998; Silva \& Ribeiro, 1992). Com base nessas informações estabeleceu-se a hipótese de que os solos coesos do Ceará, apresentam as mesmas restrições físicas identificadas em solos coesos de outros Estados brasileiros. 
O objetivo deste trabalho foi avaliar o comportamento de um solo com horizonte coeso, em área de Tabuleiros Costeiros no Estado do Ceará, analisando os parâmetros físicos: resistência tênsil, resistência do solo à penetração, densidade e porosidade do solo.

\subsection{Material e Métodos}

\subsection{1 Área de estudo}

O estudo foi realizado no município de Pacajus, litoral nordeste do Estado do Ceará, em área pertencente à Estação Experimental da EMBRAPA/CNPAT. O clima da região é do tipo Aw (clima quente com temperatura do mês mais frio superior a $18{ }^{\circ} \mathrm{C}$, sendo o verão chuvoso e o inverno seco) pela classificação de Koeppen, com precipitação pluviométrica média anual de 800 a 1100mm (Jacomine et al., 1973). O relevo regional é plano e suave ondulado com altitudes variando de 20 a $80 \mathrm{~m}$.

O solo usado neste estudo foi coletado em área cultivada com cajueiro anão, sendo classificado como Argissolo Acinzentado Distrófico arênico coeso, correspondendo ao perfil 1 (P1). Para efeito de comparação quanto à coesão do solo, utilizou-se um perfil em área sob mata preservada, próxima ao P1, classificado como Argissolo Amarelo Distrófico arênico, correspondente ao perfil 2 (P2), ambos provenientes de sedimentos arenosos e essencialmente quartzosos do Grupo Barreiras. Para avaliação do comportamento coeso foi estudado com detalhes apenas o horizonte coeso (Bt1 coeso do P1) e o não coeso (Bt1 do P2), os quais apresentam estrutura maciça tendendo a formação de blocos, e estão inseridos dentro da mesma classe textural (Tabela 1). A granulometria desses horizontes foi determinada conforme Gee \& Bauder (1986). 
Tabela 1. Frações granulométricas do horizonte coeso (Bt1 coeso) e do não coeso (Bt1)

\begin{tabular}{|c|c|c|c|c|c|c|c|c|c|c|}
\hline \multirow[t]{2}{*}{ Horizontes } & \multirow[t]{2}{*}{ Prof. } & \multicolumn{6}{|c|}{ Areia $^{(1)}$} & \multirow[t]{2}{*}{ Silte } & \multirow{2}{*}{$\begin{array}{l}\text { Argila } \\
\text { Total }\end{array}$} & \multirow{2}{*}{$\begin{array}{c}\text { Classe } \\
\text { Textural }^{(2)}\end{array}$} \\
\hline & & MG & G & M & $\mathrm{F}$ & MF & Total & & & \\
\hline & $\mathrm{m}$ & ----- & - & - & - & $-\mathrm{g} \mathrm{kg}$ & 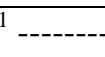 & 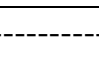 & -ב------ & \\
\hline Bt1 coeso & $0,97-1,27$ & 20 & 90 & 380 & 160 & 20 & 670 & 40 & 290 & fr. arg. arenosa \\
\hline Bt1 & $1,30-1,72$ & 0 & 80 & 420 & 170 & 30 & 700 & 20 & 280 & fr. arg. arenosa \\
\hline
\end{tabular}

O horizonte coeso e o não coeso apresentam baixos teores de matéria orgânica (M.O.), baixa capacidade de troca de cátions (CTC), baixos teores de $\mathrm{SiO}_{2}, \mathrm{Al}_{2} \mathrm{O}_{3}$ e $\mathrm{Fe}_{3} \mathrm{O}_{3}$, sendo caracterizados como bastante intemperizados (caulínitico) (Tabela 2) (Capítulo 1).

Tabela 2. Propriedades químicas do horizonte coeso (Bt 1 coeso) e do não coeso (Bt1)

\begin{tabular}{lcccccccc}
\hline \multicolumn{1}{c}{ Horizontes } & Prof. & M.O. & $\mathrm{CTC}$ & $\begin{array}{c}\mathrm{pH} \\
\mathrm{CaCl}_{2}\end{array}$ & $\mathrm{SiO}_{2}$ & $\mathrm{Al}_{2} \mathrm{O}_{3}$ & $\mathrm{Fe}_{2} \mathrm{O}_{3}$ & $\mathrm{Ki}^{(1)}$ \\
\hline \multirow{3}{*}{ Bt1 coeso } & $\mathrm{m}$ & $\mathrm{g} \mathrm{kg}^{-1}$ & $\mathrm{mmol}_{\mathrm{c}} \mathrm{kg}^{-1}$ & & $-----------\mathrm{dag} \mathrm{kg}^{-1}$ & & \\
$\mathrm{Bt} 1$ & $0,97-1,27$ & 3 & 25,2 & 3,9 & 10,4 & 8,48 & 0,89 & 2,09 \\
${ }^{(1)} \mathrm{Ki}=(\%) \mathrm{SiO}_{2} \times 1,7 /(\%) \mathrm{Al}_{2} \mathrm{O}_{3}$ & & & 19,2 & 3,4 & 9,5 & 8,15 & 1,23 & 1,98 \\
\hline
\end{tabular}

\subsubsection{Determinação da resistência tênsil}

Para a determinação da resistência tênsil (RT) foram coletadas amostras indeformadas (pequenos monólitos) em caixa de alumínio (10 x 12 x 14 cm), no horizonte coeso (Bt1 coeso) e no não coeso (Bt1), as quais foram revestidas com filme plástico e acondicionadas em caixas térmicas. No laboratório, os monólitos ainda úmidos (6,5 \%) foram desfeitos manualmente, selecionando-se 44 agregados por horizonte, com diâmetro entre 12,5 e $19 \mathrm{~mm}$, sendo posteriormente secos ao ar e em estufa a $40{ }^{\circ} \mathrm{C}$. A resistência tênsil (RT) foi determinada utilizando-se equipamento e procedimentos descritos por Imhoff et al. (2002), sendo calculada segundo Dexter \& Kroesbergen, (1985): 


$$
\mathrm{RT}=0,576 \times\left(\frac{P}{D^{2}}\right)
$$

Onde 0,576 é a constante de proporcionalidade, $\mathrm{P}$ é a força aplicada por ocasião da ruptura (N), e D é o diâmetro efetivo (m). Assumindo-se que a densidade dos agregados é constante, o diâmetro efetivo foi calculado de acordo com Watts \& Dexter (1998):

$$
\mathrm{D}=\mathrm{D}_{\mathrm{m}} \times\left(\frac{M}{M_{0}}\right)^{\frac{1}{3}}
$$

Onde $\mathrm{M}$ é a massa do agregado (g), $\mathrm{M}_{\mathrm{o}}$ é a massa média dos agregados (g), e $\mathrm{D}_{\mathrm{m}}$ é o diâmetro médio (mm). O diâmetro médio dos agregados nos conjuntos foi assumido como sendo o diâmetro médio das peneiras utilizadas para selecioná-los.

\subsubsection{Curva de resistência do solo à penetração}

Para a determinação da curva de resistência à penetração foram coletadas amostras indeformadas em anéis volumétricos $(2,4$ x 3,0 cm) no horizonte coeso e no não coeso. As amostras foram saturadas com água e submetidas a diferentes potenciais (ou tensões) mátricos $(\psi)$ utilizando mesa de tensão e câmaras de pressão segundo Klute (1986). Os $\psi$ aplicados nas amostras foram: -2, -4, -6, -10, -20, -50, -300, -1500 kPa. Após as amostras terem atingido o equilíbrio, a resistência à penetração foi medida com o auxílio de um penetrômetro eletrônico descrito por Tormena et al. (1998). Em seguida as amostras foram secas em estufa a $105^{\circ} \mathrm{C}$ e determinada à umidade e a densidade do solo (Ds) (Blake \& Hartge, 1986).

\subsubsection{Distribuição da porosidade do solo}

A porosidade total (PT) nos horizontes estudados foi calculada utilizando-se a relação, $\mathrm{PT}=\left(1-\frac{D s}{D p}\right)$, onde Dp é a densidade de partículas. Para a determinação da Dp, uma certa quantidade de TFSA (Terra Fina Seca ao Ar) foi colocada num cilindro de 
volume conhecido, o qual foi inserido numa câmara de pressão, conhecida como picnômetro de gás. Depois de atingido o equilíbrio dos gases no picnômetro, o volume de sólidos foi determinado, conforme Flint \& Flint (2002). Posteriormente a TFSA do cilindro foi levada a estufa a $105{ }^{\circ} \mathrm{C}$ para a determinação da massa de sólidos.

A distribuição da porosidade foi classificada de acordo com o diâmetro dos poros, obtidos a partir da curva de retenção de água no solo. Nessa classificação, foram considerados macroporos aqueles com diâmetro maior que 0,08 mm ( $\psi>-4 \mathrm{kPa})$; mesoporos aqueles com diâmetros entre 0,08 e 0,03 mm (-4> $\psi>-10 \mathrm{kPa})$ e microporos aqueles com diâmetros inferiores a 0,03 mm ( $\psi<-10 \mathrm{kPa})$, conforme Brewer (1976) e Luxmoore (1981).

\subsubsection{Análises estatísticas}

A normalidade dos dados de RT e Ds foi testada usando a estatística de ShapiroWilk, que testa a hipótese de nulidade, ou seja se os dados foram extraídos de uma população com distribuição normal. A estatística de Shapiro-Wilk dá o valor $W$ com um valor $p$ correspondente. A hipótese nulidade da normalidade é rejeitada quando o valor $p$ é menor que 0,05 .

\subsection{Resultados e Discussão}

\subsubsection{Resistência tênsil (RT)}

Os testes estatísticos indicam que a resistência tênsil (RT) dos agregados apresentou uma distribuição log-normal para o horizonte coeso (W= 0,98151, $\mathrm{p}<\mathrm{W}=0,7821$ ) e não coeso ( $\mathrm{W}=0,97922, \mathrm{p}<\mathrm{W}=0,69985)$ (Figura 1) corroborando com os dados apresentados por Imhoff et al. (2002) e Giarola et al. (2003).

Os agregados do horizonte coeso foram significativamente mais duros (RT = $76,65 \mathrm{kPa}$ ) que os agregados do horizonte não coeso $(\mathrm{RT}=18,88 \mathrm{kPa})$. Comparando os valores da umidade gravimétrica onde foram determinados a RT, 4,41\% e 4,19 \%, para o 
horizonte coeso e o não coeso, respectivamente, estes não apresentaram diferença estatística significativa $(\mathrm{P}>0,1)$. Este fato favorece a comparação entre os horizontes, já que a umidade do solo é um dos principais fatores que influencia a RT (Ley et al., 1989; Causarano, 1993; Perfect et al., 1995).

Os dados de RT e umidade do solo não apresentaram uma relação linear significativa, demonstrando que não houve variação no conteúdo de umidade dentro dos agregados de cada horizonte.

A diferença nos valores de RT (Bt1 coeso > Bt1 (não coeso)) também não foi influenciada pela textura do solo, pois os dois horizontes apresentam conteúdo de argila similar e estão inseridos dentro da mesma classe textural (franco argilo-arenosa) (Tabela 1). Ley et al. (1989) mostraram que a RT aumenta com o conteúdo de argila e com o aumento da Ds.

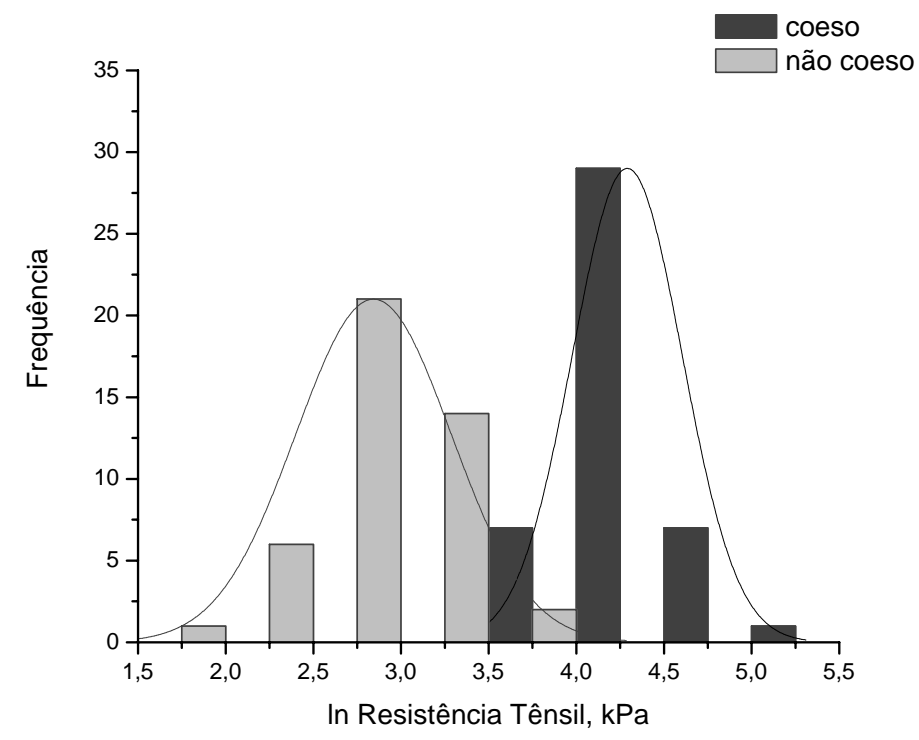

Figura 1 - Freqüência de distribuição da resistência tênsil nos horizontes coeso (Bt1 coeso) e não coeso (Bt1) 
A distribuição dos valores de RT transformados (logaritmo na base e) apresentou média \pm erro padrão de 4,291 \pm 0,047 para o Bt1 coeso e 2,843 \pm 0,067 para o Bt1 (não coeso), sendo estes valores significativamente diferentes $(\mathrm{P}<0,001)$.

Em solos hardsetting (solos australianos com comportamento semelhantes aos solos coesos), secos ao ar, foram registrados valores de RT próximos a -200 kPa (Ley et al., 1989; Gusli et al., 1994). Giarola et al. (2003), avaliando o comportamento físico de solos coesos no Estado da Bahia, encontrou valores de RT próximos a $37 \mathrm{kPa}$, bem abaixo dos valores encontrados no Ceará (76 kPa).

A relação entre o potencial de água no solo $(\psi)$ e a umidade volumétrica é mostrada na Figura 2. A curva mostra um comportamento similar para os dois horizontes a $\psi>-500 \mathrm{kPa}$, já que os valores de umidade nos $\psi=-500 \mathrm{kPa}$ não apresentaram diferença estatística entre si ao nível de 0,05 [P variou de 0,668 ( $\psi=-20$ $\mathrm{kPa})$ a $0,071(\psi=-500 \mathrm{kPa})]$. A partir de $\psi<-500 \mathrm{kPa}$ o horizonte coeso passa a reter mais água que o horizonte não coeso. Essa diferença pode ser atribuída ao adensamento das partículas no horizonte coeso, proveniente da maior Ds (Figura 4).

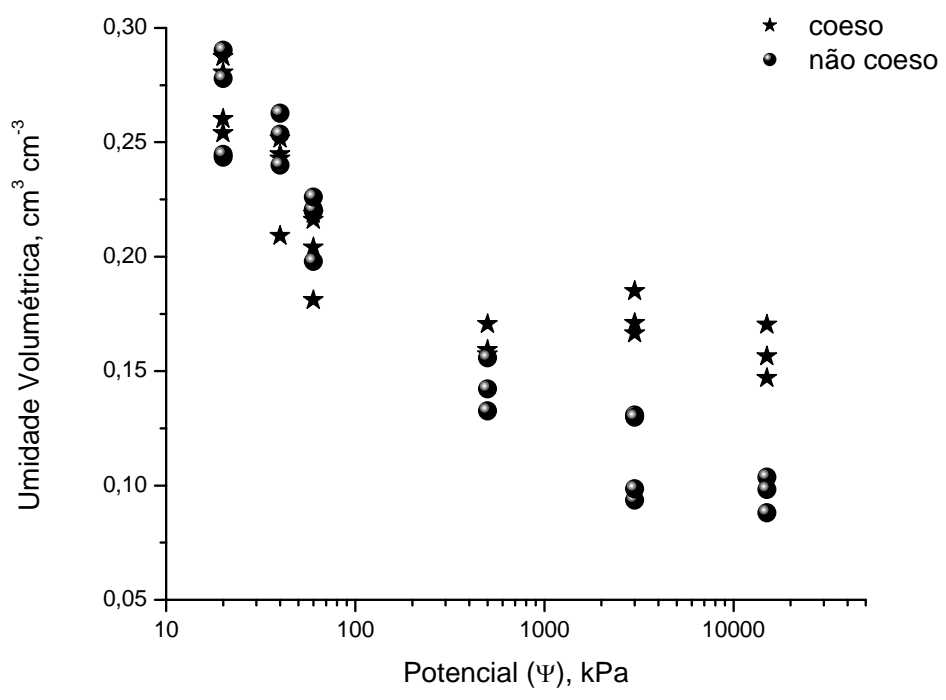

Figura 2 - Potencial de água no solo $(\psi)$ versus umidade volumétrica no horizonte coeso (Bt1 coeso) e não coeso (Bt1) 
Nos potenciais onde se tem maior retenção de água ( $\psi=-20 \mathrm{kPa}$ a $\psi=-60 \mathrm{kPa})$, a curva de resistência à penetração, para os dois horizontes, apresenta o mesmo comportamento (Figura 3). Com a diminuição da umidade do solo $\left(>0,15 \mathrm{~cm}^{3} \mathrm{~cm}^{-3}\right)$ as linhas da curva divergem, ilustrando que a diferença da RP nos horizontes, além de ser influenciada pela densidade do solo, sofre influência do conteúdo de água no solo, sendo a RP maior no horizonte coeso. Para o horizonte não coeso foram observadas pequenas diferenças no desenvolvimento da RP com a variação da umidade do solo.

Observando-se a Figura 3, nota-se que os valores de RP atingiram um valor de 3 MPa em conteúdos de umidade próximos a $0,13 \mathrm{~cm}^{3} \mathrm{~cm}^{-3}$, o que corresponde a aproximadamente $-500 \mathrm{kPa}$. De acordo com Mullins (1997), valores de RP próximos a 3 MPa são suficientes para impedir o crescimento ou a emergência das plantas.

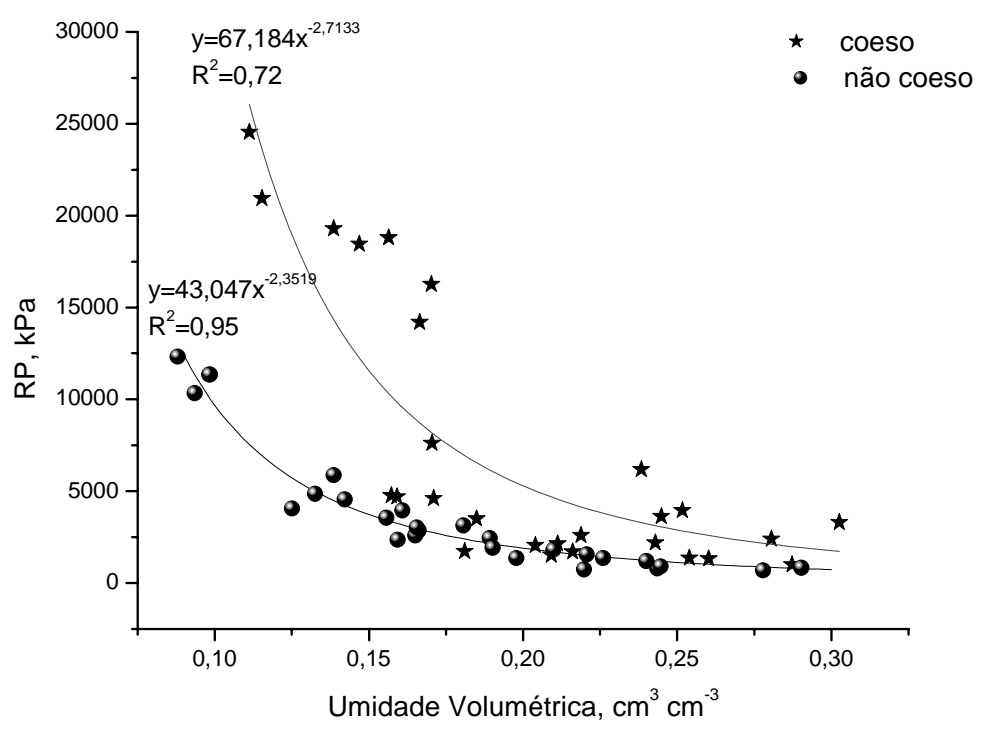

Figura 3 - Resistência do solo à penetração versus umidade volumétrica no horizonte coeso (Bt1 coeso) e não coeso (Bt1)

Com base nos dados apresentados pode-se inferir que o aumento da RP no coeso está diretamente relacionado com a diminuição do conteúdo de água e com o aumento da Ds. De acordo com Smith et al. (1997), a RP é fortemente influenciada pelo grau de compactação do solo, que é por sua vez influenciada pela Ds. A presença de materiais 
finos, como argila e silte, também contribui com o aumento da RP do solo seco, atuando como pontes que conectam as partículas de areia (Mullins, 1997).

A força exercida pelas ligações existentes entre as partículas do solo e o potencial mátrico, tem efeito similar à aplicação de uma força externa (Mullins et al., 1987). Pois, apesar do ar entrar nos espaços entre os grãos de areia durante a secagem do solo, este só penetra na matrix fina em baixos valores de potencial mátrico (>-1 MPa), o que pode contribuir para uma maior resistência do solo (Mullins \& Panayiotopoulos, 1984). Esta explicação dá indícios de como a resistência pode variar com o conteúdo de umidade, pois uma queda acentuada do potencial mátrico, numa faixa estreita de umidade, resulta em aumento acentuado da resistência do solo.

Comparando dados da curva de resistência à penetração, o solo coeso do Estado do Ceará possui valores de RP muito superiores (25 MPa) aos observados em solos coesos da Bahia (4,5 MPa) (Giarola et al., 2003), considerando a mesma faixa de umidade $\left(0,1\right.$ a $\left.0,15 \mathrm{~cm}^{3} \mathrm{~cm}^{-3}\right)$ e a ocorrência de características físicas semelhantes.

A freqüência de distribuição da Ds mostra-se normal para o horizonte coeso (W= 0,9874, $\mathrm{p}<\mathrm{W}=0,9118$ ) e para o não coeso ( $\mathrm{W}=0,9917, \mathrm{p}>\mathrm{W}=0,9986$ ) (Figura 4), corroborando com diversos trabalhos que apresentam a Ds como uma variável de distribuição normal (Nielsen et al., 1973; Silva et al., 1997; Giarola et al., 2003).

$\mathrm{O}$ valor de Ds foi significativamente maior $(\mathrm{P}<0,001)$ no horizonte coeso, com média e erro padrão de $1,75 \pm 0,008 \mathrm{~g} \mathrm{~cm}^{-3}$, do que no horizonte não coeso $(1,52 \pm$ 0,018). Essa diferença sugere que a Ds foi o principal fator que influenciou a resistência do solo entre os dois horizontes, levando à ocorrência do horizonte Bt coeso.

O horizonte coeso (Bt1 coeso) apresentou Ds $\left(1,75 \mathrm{~g} \mathrm{~cm}^{-3}\right)$ superior a observada em horizonte coeso (BA) no Estado de Sergipe $\left(1,72 \mathrm{~g} \mathrm{~cm}^{-3}\right)$, apesar destes solos estarem inseridos na mesma classe taxonômica (Argissolos Acinzentados) e possuírem a mesma classe textural (franco argilo-arenosa). Contudo, diferem quanto ao tipo de horizonte, profundidade de ocorrência e conteúdo de matéria orgânica. 


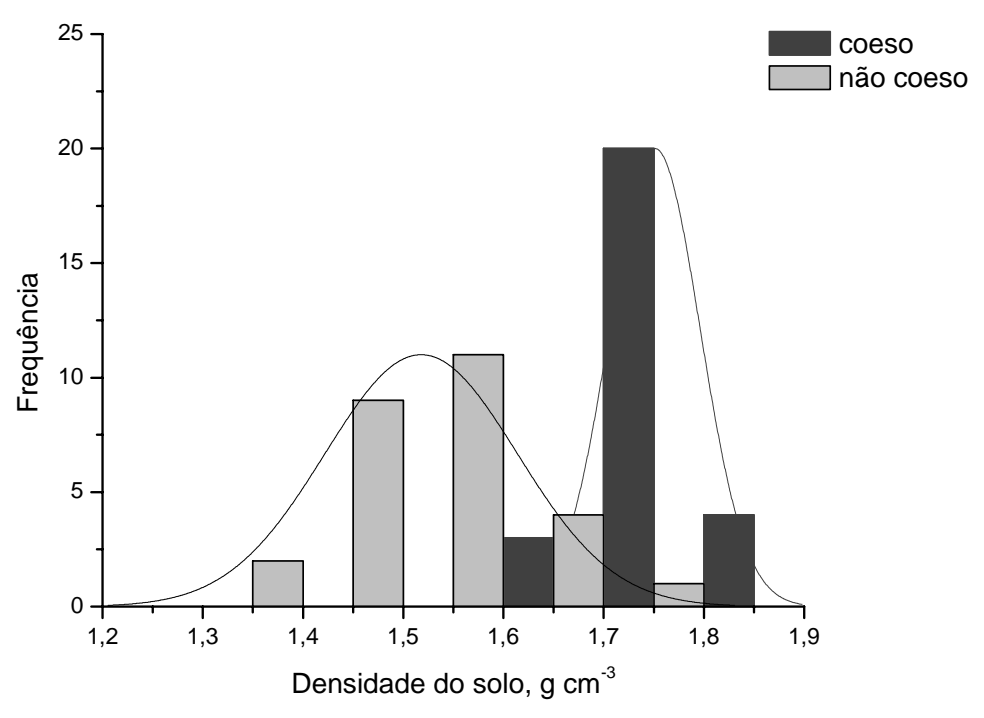

Figura 4 - Freqüência de distribuição da Ds no horizonte coeso (Bt coeso) e não coeso (Bt sob mata)

Estudos realizados em Latossolos Amarelos coesos, nos Estados de Alagoas e Bahia (Silva et al., 1998; Giarola et al., 2003), encontraram valores de Ds, respectivamente, de $1,42 \mathrm{~g} \mathrm{~cm}^{-3}$ e 1,57 $\mathrm{g} \mathrm{cm}^{-3}$, sendo ambos inferiores aos observados na classe dos Argissolos Acinzentados coesos.

A Ds é um dos parâmetros físicos do solo mais usados para quantificar a compactação do solo, principalmente quando são comparados solos com as mesmas características (Silva et al., 1997).

A distribuição do tamanho dos poros, em classes, está apresentada na figura 5. Observa-se que os valores da porosidade total no horizonte coeso, com média e erro padrão de $0,34 \pm 0,002 \mathrm{~cm}^{3} \mathrm{~cm}^{-3}$, foram significativamente menores do que o horizonte não coeso, 0,42 $\pm 0,006 \mathrm{~cm}^{3}$. O menor volume de poros total no horizonte coeso é acompanhado por redução similar dos macroporos e mesoporos, onde o horizonte coeso $\left(0,10 \pm 0,004 ; 0,02 \pm 0,001 \mathrm{~cm}^{3} \mathrm{~cm}^{-3}\right)$ foi significativamente menor $(\mathrm{P}<0,001)$ que o não coeso $\left(0,19 \pm 0,006 ; 0,04 \pm 0,001 \mathrm{~cm}^{3} \mathrm{~cm}^{-3}\right)$.

O menor volume de poros do horizonte coeso (Figura 5) tem efeito marcante sobre o aumento da resistência à penetração, durante o período seco, e sobre a densidade 
do solo. Em solos adensados, como é o caso dos horizontes coesos, os poros originalmente grandes são comprimidos, refletindo em redução no volume total de poros e, provavelmente, na redução do volume de macroporos. Guérif (1990) e Munkholm et al. (2002) mostram uma forte correlação negativa entre macroporos e resistência tênsil.

Há predomínio do volume de microporos nos dois horizontes, onde o coeso apresenta média e erro padrão de $0,20 \pm 0,004$ e o não coeso de $0,19 \pm 0,002$, sendo $\mathrm{P}=$ 0,007. O predomínio de microporos no horizonte coeso explica o fato deste reter maior quantidade de água que o horizonte não coeso.

A maior quantidade de microporos se deve ao fato destes ficarem posicionados dentro dos agregados, de forma a serem inatingidos pelos processos que ocorrem no solo, somando-se aos outros microporos que são criados quando ocorre adensamento, aumentando dessa forma, o volume total de poros muito pequenos nos horizontes coesos (Cintra \& Libardi, 1998).

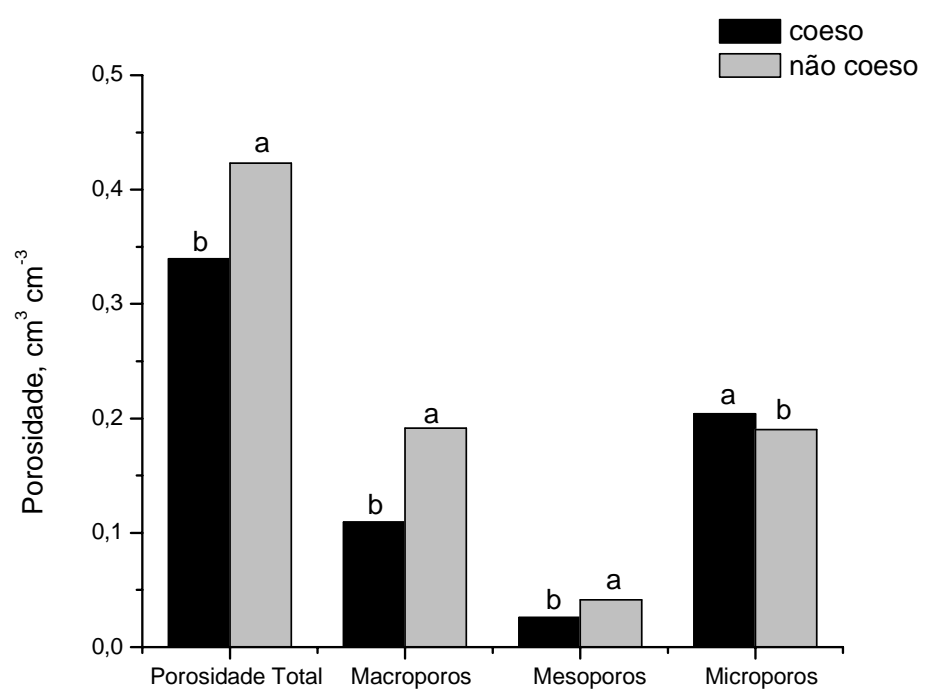

Figura 5 - Distribuição da porosidade total, macroporos, mesoporos e microporos no horizonte coeso (Bt1 coeso) e não coeso (Bt1 - sob mata). Médias seguidas da mesma letra, nas colunas, não diferem entre si a 5 \% pelo teste de Tukey

De acordo com Cintra \& Libardi (1998), uma das principais conseqüências negativas dos horizontes coesos é a diminuição no volume total de poros, já que a 
alteração na porosidade afetará a atividade biológica, o movimento e a capacidade de retenção de água, bem como, a sua disponibilidade para as plantas.

Os valores da porosidade do solo indicam um possível arranjamento natural de suas partículas, já que o horizonte Bt1 coeso não sofreu alteração pelo manejo do solo, pois se encontra a $0,97 \mathrm{~m}$ de profundidade.

\subsection{Conclusão}

O trabalho confirmou a hipótese de que os solos coesos do Ceará, apresentam as mesmas restrições físicas identificadas em solos coesos de outros Estados brasileiros.

Os valores de resistência tênsil, resistência do solo à penetração e densidade do solo, mostraram-se mais elevados no solo coeso do Ceará do que em outras áreas de Tabuleiros Costeiros estudadas no Brasil. 


\section{MICROMORFOLOGIA E ANÁLISE DE IMAGENS DE UM ARGISSOLO ACINZENTADO COESO NO ESTADO DO CEARÁ}

\section{Resumo}

O uso da micromorfologia e da análise de imagens no estudo mais detalhado da porosidade do solo, poderá fornecer subsídios que possibilitem melhor compreender a elevada resistência oferecida pelos horizontes coesos durante o secamento do solo. Com base nisso, estabeleceu- se à hipótese de que o adensamento natural existente nos horizontes coesos além de influenciar na quantidade de poros, também influencia o seu formato e sua orientação. O objetivo deste trabalho foi avaliar a diferença na distribuição do espaço poroso, bem como, o formato, tamanho e orientação dos poros através de estudos micromorfológicos e análise de imagens, em um Argissolo Acinzentado coeso localizado no Estado do Ceará. Para isso foram utilizados descrições micromorfológicas de lâminas delgadas e estudo de análise de imagens em blocos impregnados com resina poliéster e contraste ultravioleta. A quantificação da porosidade foi feita utilizando o software Noesis-Visilog 5.4. Os resultados mostram que o adensamento natural existente nos horizontes coesos além de influenciar na quantidade de poros, também influencia o seu formato e sua orientação, e que as áreas adensadas, medidas por análise de imagem, no horizonte coeso foram os principais fatores que influenciaram o espaço poroso do solo, sendo responsável pelo aumento da sua resistência. 


\section{MICROMORPHOLOGY AND IMAGE ANALYSIS OF AN HARDSETTING GRAY ARGISOL IN THE STATE OF CEARA}

\section{Summary}

The use of the micromorphology and the image analysis in the detailed study of the soil porosity may provide subsidies to make possible to better understand the high resistance offered by hardsetting horizons during the soil drying. It was established the hypothesis that the natural compaction found in the hardsetting horizons influences the amount of pores, as well as their shape and orientation. The objective of this work was to evaluate the difference in the pore size distribution as well as the shape and orientation of the pores through micromorphological studies and images analysis in a hardsetting Gray Argisol located in the State of Ceara. Thin sections and blocks impregnated with polyester resin and ultraviolet contrast were used to carry out the micromorphological and the image analysis studies. The quantification of the soil porosity was made using the software Noesis-Visilog 5.4. The results show that the existent natural compaction in the hardsetting horizons influences the amount of pores, as well as their shape and orientation, and that the denser areas, measured by image analysis, in the hardsetting horizon were the main factor that influenced the soil porosity, being responsible for the increase of the soil resistance.

\subsection{Introdução}

Solos com horizontes coesos ocorrem em toda a faixa litorânea brasileira ocupada pelos Tabuleiros Costeiros (Jacomine, 1996), e caracterizam-se por apresentar um incremento acentuado na sua resistência (a ponto de restringir o preparo do solo e o desenvolvimento das culturas), devido o mesmo apresentar-se duro a extremamente duro, quando seco e friáveis quando úmidos (esborroando-se completamente quando submetido a pressões) (Jacomine, 1996; Ribeiro, 1998; Embrapa, 1999; Giarola \& Silva, 2002). 
A origem dos horizontes coesos ainda é assunto polêmico, podendo estar associada a vários processos simultâneos, como por exemplo: agrupamento das partículas de argila face a face; perda do plasma argiloso da camada superficial para as subjacentes (argiluviação); presença de compostos orgânicos pouco polimerizados; presença de sílica secundária, ferro e alumínio dispersos nos microporos; adensamento resultante da alteração da estrutura do solo pela alternância de ciclos de umedecimento e secagem; contribuição da areia fina (Ribeiro, 1986; Ponte \& Ribeiro, 1990; Jacomine, 1996; Araújo Filho et al., 2001; Giarola \& Silva, 2002; Rezende et al., 2002).

A elevada coesão desses horizontes tem efeito direto no espaço poroso do solo e, conseqüentemente, prejudica a dinâmica da água, do ar e dos nutrientes, a temperatura do meio, a atividade biológica e o crescimento e desenvolvimento do sistema radicular das plantas, com reflexos negativos na produção agrícola (Rezende et al., 2002).

No Brasil há uma grande necessidade entre os pesquisadores de conhecer com mais detalhes o comportamento dos solos com caráter coeso, bem como, de definir parâmetros que identifiquem de forma fácil e segura a presença desse atributo no solo. Este tipo de comprometimento, provavelmente, é subestimado em muitos solos devido à falta de critérios mais específicos para a sua identificação.

Em muitas partes do mundo a análise de imagens vem sendo desenvolvida e aperfeiçoada por diversos micromorfologistas, como uma técnica eficiente para a quantificação da estrutura, espaço poroso, distribuição dos poros, bem como, para a caracterização da irregularidade, orientação, forma e tamanho dos poros, através do uso de lâminas delgadas ou blocos de solo (Bouma, 1977; Ringrose-Voase, 1987; Protz et al., 1987; Ringrose-Voase, 1991; Thompson et al., 1992; Bouabid et al., 1992; Deeks et al., 1999).

De acordo com Protz et al. (1987), a aplicação da análise de imagem computadorizada para medir a porosidade e a estrutura do solo está se tornando parte integral das pesquisas de solo, principalmente as que avaliam o sistema de manejo, fornecendo bases quantitativas para descrição e levantamentos de solos, o que permite medidas exatas para componentes normalmente estimados a olho no campo (Murphy et al., 1977). 
A utilização dessa técnica no estudo mais detalhado da porosidade do solo, poderá fornecer subsídios que possibilitem melhor compreender a elevada resistência oferecida pelos horizontes coesos durante o secamento do solo. Pode-se estabelecer à hipótese de que o adensamento natural existente nos horizontes coesos além de influenciar na quantidade de poros, também influencia o seu formato e sua orientação.

O objetivo deste trabalho foi avaliar a diferença na quantificação e distribuição do espaço poroso, bem como, o formato, tamanho e orientação dos poros através de estudos micromorfológicos e análise de imagens, em um Argissolo Acinzentado coeso localizado no Estado do Ceará.

\subsection{Material e Métodos}

Dois perfis de solo (P1 e P2) foram estudados na área pertencente à Estação Experimental da EMBRAPA/CNPAT na cidade de Pacajus - CE, ambos derivados de sedimentos arenosos da Formação Barreiras e localizados em área de Tabuleiros Costeiros.

O perfil (P1) encontra-se do lado esquerdo da entrada principal do CNPAT, sob cultivo de cajueiro, implantado a \pm 10 anos e localizado na parte mais baixa da paisagem, sendo o relevo local plano. O perfil (P2) foi utilizado para efeito de comparação quanto à coesão do solo, já que ambos possuem as mesmas características físicas (Tabela 1), mas morfologias distintas (Tabela 2), estando o mesmo localizado em área sob mata, distante aproximadamente $2 \mathrm{~km}$ do perfil P1, e na posição mais alta da paisagem.

De acordo com o Sistema Brasileiro de Classificação de Solos (Embrapa, 1999), os solos foram assim classificados:

P1 - Argissolo Acinzentado Distrófico arênico coeso A moderado textura arenosa/média fase caatinga litorânea relevo plano.

P2 - Argissolo Amarelo Distrófico arênico A moderado textura arenosa/média fase caatinga litorânea relevo plano. 
Tabela 1. Frações granulométricas do horizonte coeso (Bt1 coeso) e do não coeso (Bt1)

\begin{tabular}{|c|c|c|c|c|c|c|c|c|c|c|}
\hline \multirow[t]{2}{*}{ Horizontes } & \multirow[t]{2}{*}{ Prof. } & \multicolumn{6}{|c|}{ Areia $^{(1)}$} & \multirow[t]{2}{*}{ Silte } & \multirow{2}{*}{$\begin{array}{l}\text { Argila } \\
\text { Total }\end{array}$} & \multirow{2}{*}{$\begin{array}{c}\text { Classe } \\
\text { Textural }^{(2)}\end{array}$} \\
\hline & & MG & G & M & $\mathrm{F}$ & MF & Total & & & \\
\hline & $\mathrm{m}$ & $\overline{c----}$ & - & - n & ----- & $-\mathrm{g} \mathrm{kg}$ & 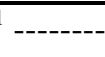 & ---- & ----- & \\
\hline Bt1 coeso & $0,97-1,27$ & 20 & 90 & 380 & 160 & 20 & 670 & 40 & 290 & fr. arg. arenosa \\
\hline Bt1 & 1,30-1,72 & 0 & 80 & 420 & 170 & 30 & 700 & 20 & 280 & fr. arg. arenosa \\
\hline
\end{tabular}

Tabela 2. Características morfológicas do horizonte coeso (Bt1 coeso) e do não coeso (Bt1)

\begin{tabular}{|c|c|c|c|c|c|c|}
\hline \multirow[t]{2}{*}{ Horizontes } & \multirow[t]{2}{*}{ Prof. } & \multicolumn{2}{|c|}{ Cor } & \multirow[t]{2}{*}{ Estrutura $^{1}$} & \multicolumn{2}{|c|}{ Consistência $^{2}$} \\
\hline & & Seca & Úmida & & Seca & Úmida \\
\hline & $\mathrm{M}$ & \multicolumn{2}{|c|}{ Munsell } & & & \\
\hline Bt1 (coeso) & $0,97-1,27$ & 10YR 7/1 & 10YR 7/2 & mac. c/ tend. à formação de bl. & Ext. dura & fr./firme \\
\hline Bt1 & $1,30-1,72$ & $10 \mathrm{YR} 6 / 6$ & 2,5 YR 5/8 & mac. c/ tend. à formação de bl. & macia/lg.dura & fr./firme \\
\hline
\end{tabular}

Foram coletadas amostras indeformadas de solo nos horizontes Bt1 coeso (coeso) do P1 e no horizonte Bt1 (não coeso) do P2, em caixas do tipo Kubiena (12 x 7 x 6 cm). Após a coleta as amostras foram enviadas para o laboratório de Micromorfologia da UFRPE, onde foram impregnadas, cortadas e polidas.

Para manter a porosidade funcional do solo as amostras passaram por um processo de substituição da água por acetona, conforme Murphy (1986). Em seguida foram impregnadas com resina poliéster e contraste ultravioleta, seguindo o método proposto por Jongerius \& Heintzberger (1975). Sendo utilizado o sistema automático PM2A da Logitech para desbaste dos blocos.

Para a quantificação da porosidade pelo método da análise de imagens, os blocos de solo impregnados foram iluminados com luz ultravioleta e fotografados com o auxílio de uma câmara Zeiss MC 63A, acoplada ao microscópio petrográfico. As fotos foram digitalizadas no Canon CanoScan FB620P, com resolução de 339 x 230 pixels e avaliadas em software de análise de imagem Noesis-Visilog 5.4.

Para a distribuição de tamanho dos poros foram retiradas fotografias nas áreas abertas (menos adensadas) e adensadas dos blocos, nos horizontes coeso (Bt1 coeso) e 
não coeso (Bt1), com o auxílio de microscópio petrográfico e lente óptica de 20x, sendo 1 pixel $=25 \mu \mathrm{m}^{2}$, foram feitas seis repetições para cada horizonte, sendo que os pixels com valores inferiores a $125 \mu \mathrm{m}^{2}\left(0,000125 \mathrm{~mm}^{2}\right)$ foram descartados, devido não apresentarem tamanhos adequados para definição confiável dos formatos dos poros.

Os parâmetros utilizados para definição da forma dos poros foram determinados conforme Cooper (1999) e para distribuição da orientação dos poros, segundo Murphy et al. (1977) e Sort \& Alcãniz (1999).

A distribuição do tamanho dos poros corresponde a um aumento constante do logaritmo decimal da superfície dos poros da razão de 1,78 (Cooper, 1999).

Para a determinação da forma dos poros foi utilizando o seguinte índice:

$$
I_{1}=\frac{P^{2}}{4 \pi \mathrm{A}}
$$

onde $\mathrm{P}$ é o perímetro do poro e A é a área que ocupa. Este índice é igual a 1 para uma forma perfeitamente circular, e é maior quando a sua forma desvia-se do círculo.

O segundo índice utilizado para definição da forma, foi proposto por Cooper (1999):

$$
I_{2}=\frac{\frac{1}{m} \sum_{i}\left(N_{I}\right) i}{\frac{1}{n} \sum_{j}\left(D_{F}\right) j}
$$

onde $\mathrm{m}$ = número de direções $i$ nas quais são calculados o número de interceptos $N_{I}$, (i $=0,45,90$ e $\left.135^{\circ}\right)$; e $n=$ número de direções $\mathrm{j}$ nas quais são calculados os diâmetros de Feret $D_{F},\left(\mathrm{j}=0\right.$ e $\left.90^{\circ}\right)$. Sendo o índice $I_{2}$ utilizado para complementar o índice $I_{1}$, de acordo com a Tabela 3. A Tabela 4 apresenta o limite das classes de tamanho dos poros. 
Tabela 3. Definição das classes de forma dos poros

\begin{tabular}{lcc}
\hline \multicolumn{1}{c}{ Poros } & \multicolumn{2}{c}{ Índice de forma } \\
& $I_{1}$ & $I_{2}$ \\
\hline Arredondados (Arr) & $I_{1} \leq 5$ & \\
Alongados (Alon) & $5<I_{1} \leq 25$ & $\leq 2,2$ \\
Complexos (Comp) & $5<I_{1} \leq 25$ ou $>25$ & $\geq 2,2$ \\
\hline
\end{tabular}

A classificação dos poros arredondados foi feita somente pela obtenção do índice $I_{1}$, já a classificação dos alongados deve-se considerar os dois índices, ou seja, foi classificado como alongado todo poro cujo índice $5<I_{1} \leq 25$ e com $I_{2} \leq 2$,2. Portanto, o índice $I_{2}$ permite fazer a distinção entre alongados e complexos. Para valores de $I_{1}>25$, os poros foram classificados como complexos, independentes dos valores de $I_{2}$.

Tabela 4. Definição das classes de tamanho versus forma dos poros

\begin{tabular}{cccc}
\hline Classes de tamanho em $\mathrm{mm}^{2}$ & \multicolumn{3}{c}{ Classes de forma* } \\
& Arredondados $^{*}$ & Alongados & Complexos \\
\hline$\leq 0,001$ & $\operatorname{Arr}_{\mathrm{p}}$ & Alon $_{\mathrm{p}}$ & Comp $_{\mathrm{p}}$ \\
$>0,001 \mathrm{e} \leq 0,01$ & $\operatorname{Arr}_{\mathrm{m}}$ & Alon $_{\mathrm{m}}$ & Comp $_{\mathrm{m}}$ \\
$>0,01$ & $\operatorname{Arr}_{\mathrm{g}}$ & Alon $_{\mathrm{g}}$ & Comp $_{\mathrm{g}}$ \\
\hline
\end{tabular}

*p=pequeno; $\mathrm{m}=$ =médio e $\mathrm{g}=$ grande

A determinação da orientação dos poros foi feita com base nos diâmetros verticais (Fv) e horizontes (Fh) de Feret, usando a seguinte fórmula: $+\left(\frac{F v}{F h}-1\right)$ ou $\left(\frac{F h}{F v}-1\right)$. Onde o numerador é o valor maior (Murphy et al., 1977). Para os dados de orientação foram considerados apenas os poros alongados. 


\subsection{Resultados e Discussão}

\subsubsection{Descrição micromorfológica}

As descrições das principais características micromorfológicas são apresentadas de forma resumida na Tabela 5.

A contextura matricial (trama) do horizonte coeso apresenta-se predominantemente porfírica do tipo simples (fechada) (Stoops \& Jongerius, 1975), abrangendo 80\% da superfície da lâmina, onde a fração fina preenche todos os espaços vazios existente entre as frações grosseiras (Figura 1a). Porém, ocorrem algumas áreas mais abertas intermediárias do tipo quito-enaúlica, ocupando $20 \%$ da superfície da lâmina, onde a micromassa (plasma) em parte reveste as frações grosseiras e em parte preenche parcialmente os espaços vazios entre essas frações (Figura 1c).

A contextura do tipo porfírica também foi observada por Silva et al. (1998), Ferreira et al. (1999a), Araújo Filho et al. (2001) e Giarola et al. (2003) em solos coesos no Brasil e por Chartres \& Norton (1994) em solos "hardsetting” na Austrália. Resultados encontrados por Silva et al. (1998) mostram que a matriz de um horizonte coeso não se apresenta totalmente densa, ocorrendo também áreas mais abertas do tipo enáulica, corroborando os resultados encontrados.

O horizonte não coeso apresenta contextura predominantemente do tipo enáulica (Stoops \& Jongerius, 1975), abrangendo $40 \%$ da superfície da lâmina, onde a micromassa (plasma) ocorre como agregados distintos existentes nos espaços intergranulares (Figura 1d), sendo que, ocorrem algumas áreas mais adensadas do tipo porfírica (30\% da superfície da lâmina) (Figura 1b) e outras intermediárias do tipo porfiro-enáulica (30\% da superfície da lâmina). A presença de áreas adensadas no horizonte não coeso (sob mata) indica uma pedogênese que pode contribuir na formação de uma camada coesa.

O horizonte coeso é predominantemente maciço, porém, nas áreas mais abertas, observam-se pontos onde há tendências à formação de agregados bem definidos, do tipo 
poliédricos angulares a subangulares, com pedalidade dominante do tipo moderada a fortemente desenvolvida.

O horizonte não coeso apresenta predominância de agregados poliédricos angulares a subangulares, com pedalidade variando de moderada a forte. Em algumas áreas há formação de agregados microgranulares, arredondados, semelhantes a pelotas fecais, caracterizando uma estrutura micropédica, típica de Oxissolos (Stoops \& Buol, 1985). Tais agregados aparecem de forma isolada, ou ligados uns aos outros, formando agregados maiores e áreas mais adensadas.

Nos Latossolos cauliníticos estudados por Ferreira et al. (1999a) observou-se que o ajuste face a face das placas de caulinita induziu uma baixa tendência ao desenvolvimento de microestrutura, o que favoreceu o desenvolvimento de uma estrutura em blocos, maior densidade do solo, maior proporção de poros pequenos e menor permeabilidade.

As frações grosseiras apresentam várias similaridades entre os dois horizontes estudados, tais como: formato, tamanho, grau de seleção dos grãos e composição mineralógica, constituída basicamente por grãos de quartzo, arestados e desarestados, com grau de esfericidade bastante variável, sendo observada também a ocorrência (traços) de microclina, opacos e pretos e grãos muito pequenos de muscovita. Tais similaridades além de conferir a mesma granulometria aos dois horizontes (Tabela 1), também ressaltam as indicações que esses solos provém do mesmo material de origem (Mermut, 1992), e que as diferenciações observadas nos dois horizontes podem ser impostas pelo posicionamento na paisagem (Melo \& Santos, 1996; Ribeiro, 1998).

A fração fina (micromassa) dos dois horizontes também possui a mesma mineralogia (predominantemente caulinítica), diferindo na cor, devido à ocorrência de processos de redução do ferro (má drenagem) no horizonte coeso, o que atribui ao solo uma coloração amarela acinzentado bastante uniforme. A fração fina do horizonte não coeso apresenta coloração avermelhada na maior parte da lâmina havendo áreas com cores vermelhas mais cromáticas correspondentes a mosqueados. Sob luz polarizada a fração fina dos dois horizontes apresenta contextura ou trama de birrefringência 
indiferenciada, porém, com predomínio de estrias ao redor dos grãos de quartzo (granoestriada) e dos poros (poroestriada) e distribuídas em várias direções.

A presença de estrias no solo é atribuída a pressões exercidas pela expansibilidade das argilas ou a características herdadas do material de origem, entretanto, essas estrias apresentam mais de uma orientação preferencial quando há mudanças na direção das pressões aplicadas (Mermut, 1992). Conforme o mesmo autor o predomínio de caulinita na mineralogia dos solos estudados favorece a orientação do plasma, bem como, justifica a ausência de fissuras estruturais (Mullins et al., 1987)

Os poros do tipo canais e cavidades no horizonte coeso aparecem de forma descontínua, com presença de numerosas microfissuras não comunicantes nas áreas mais adensadas, esses poros não comunicantes podem se comportar como reservatórios de água, favorecendo a sua retenção. No horizonte não coeso os agregados formam poros estruturais comunicantes, caracterizando a ocorrência de poros do tipo empacotamento complexo nas áreas mais abertas, provenientes da atividade biológica. Esse horizonte apesar de está localizado em área sob mata não apresenta fragmentos de plantas, nem indicadores da presença de mesofauna no solo.

Como feição pedológica textural para os dois horizontes, destaca-se o preenchimento de canais por argila de natureza iluvial, límpida, sem microlaminações (caulinitãs), como também, a presença de poucos e pequenos nódulos constituídos por minerais opacos e pretos nos dois horizontes. Contudo a presença de argila iluvial ou cutãs de iluviação no coeso é muito pequena, comprovando que o adensamento natural observado nas lâminas, evidenciado também pelo aumento da densidade do solo (Ds) (Capítulo 4), é originado de outro processo pedogenético e não formado somente a partir de migrações de argilas de horizontes subjacentes. 
Tabela 5. Resumo das descrições micromorfológicas

\begin{tabular}{|c|c|c|}
\hline \multirow{2}{*}{ Atributos } & \multicolumn{2}{|c|}{ Horizontes } \\
\hline & Bt1 coeso (104-116 cm) & Bt1 (não coeso) (147-159cm) \\
\hline $\begin{array}{l}\text { Contextura } \\
\text { matricial }\end{array}$ & $\begin{array}{l}\text { Predominantemente porfírica }(80 \%) \text {, com } \\
\text { algumas áreas mais abertas intermediárias do } \\
\text { tipo quito-enáulica }(20 \%) \text {. }\end{array}$ & $\begin{array}{l}\text { Predominantemente enáulica ( } 40 \% \text { ), sendo que } \\
\text { algumas áreas apresentam-se mais adensadas do } \\
\text { tipo porfírica (30\%) e outras intermediárias tipo } \\
\text { porfiro-enáulica (30\%). }\end{array}$ \\
\hline Estrutura & $\begin{array}{l}\text { Solo Predominantemente maciço. Em alguns há } \\
\text { tendência a formação de agregados mal } \\
\text { definidos. Pedalidade fracamente desenvolvida. }\end{array}$ & $\begin{array}{l}\text { Agregados poliédricos subangulares, com } \\
\text { pedalidade moderada a fortemente } \\
\text { desenvolvida. Em algumas áreas mais abertas } \\
\text { (provenientes de atividades biológicas) há } \\
\text { formação de estruturas microgranulares típicas } \\
\text { de latossolos. }\end{array}$ \\
\hline $\begin{array}{l}\text { Fração } \\
\text { grosseira } \\
\text { inorgânica }\end{array}$ & $\begin{array}{l}\text { Grãos de quartzo arestados e desarestados com } \\
\text { esfericidade variável. Ocorrência (traços) de } \\
\text { microclina, opacos pretos e provavelmente } \\
\text { muscovita (grãos muito pequenos). }\end{array}$ & $\begin{array}{l}\text { Grãos de quartzo arestados e desarestados com } \\
\text { esfericidade variável. Ocorrência (traços) de } \\
\text { microclina, opacos pretos e provavelmente } \\
\text { muscovita (grãos muito pequenos). }\end{array}$ \\
\hline $\begin{array}{l}\text { Micromassa } \\
\text { (Plasma) }\end{array}$ & $\begin{array}{l}\text { Coloração amarelo acinzentado bastante } \\
\text { uniforme. } \\
\text { indiferenciada. Contextura bredomínio de estrias: } \\
\text { granoestriadas, poroestriadas e distribuídas ao } \\
\text { acaso. }\end{array}$ & $\begin{array}{l}\text { Coloração amarelo avermelhado na maior parte } \\
\text { da lâmina, com presença de mosqueados mais } \\
\text { avermelhados. Contextura-b indiferenciada. } \\
\text { Áreas apresentam pequenos domínios de argila } \\
\text { orientada, distribuídas ao acaso, formando a } \\
\text { contextura-b salpicada granida ("stipple- } \\
\text { speckled”), ou em volta de grãos de areia } \\
\text { definindo a contextura-b granoestriada. }\end{array}$ \\
\hline Poros & $\begin{array}{l}\text { Presença de canais e cavidades. Nas áreas mais } \\
\text { abertas há poros de empacotamento complexo } \\
\text { provenientes da atividade biológica e nas áreas } \\
\text { mais adensadas presença de microfissuras. }\end{array}$ & $\begin{array}{l}\text { Predominância de cavidades e canais. } \\
\text { Ocorrência de poros de empacotamento } \\
\text { complexo nas áreas mais abertas, provenientes } \\
\text { da atividade biológica. }\end{array}$ \\
\hline $\begin{array}{l}\text { Feições } \\
\text { pedológicas } \\
\text { texturais }\end{array}$ & $\begin{array}{l}\text { Preenchimento de canais por argila de natureza } \\
\text { iluvial com orientação forte contínua (raros), } \\
\text { límpida, com e sem micro-laminações } \\
\text { (caulinitãs). }\end{array}$ & $\begin{array}{l}\text { Preenchimento de canais por argila de natureza } \\
\text { iluvial, límpida, sem micro-laminações } \\
\text { (caulinitãs). }\end{array}$ \\
\hline $\begin{array}{l}\text { Feições } \\
\text { pedológicas } \\
\text { amorfas e } \\
\text { criptocristalina }\end{array}$ & $\begin{array}{l}\text { Presença de poucos e pequenos nódulos } \\
\text { constituídos por minerais opacos e pretos. }\end{array}$ & $\begin{array}{l}\text { Presença de poucos e pequenos nódulos } \\
\text { constituídos por minerais opacos e pretos. }\end{array}$ \\
\hline
\end{tabular}

De acordo com Ribeiro (2001), é rara a ocorrência de cutãs de iluviação em horizontes coesos, sendo que geralmente o material mineral está associado à matéria orgânica e aos poros, ocorrendo geralmente no topo do horizonte coeso. 


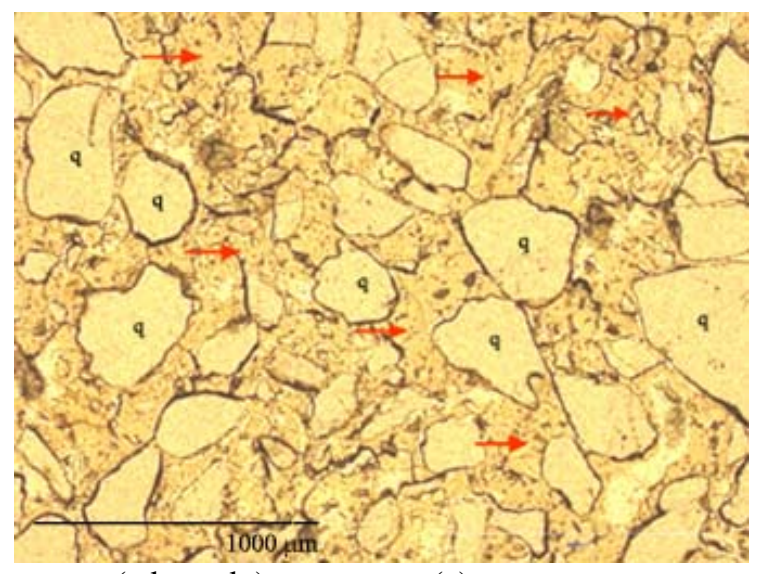
coeso (adensado)

(a)

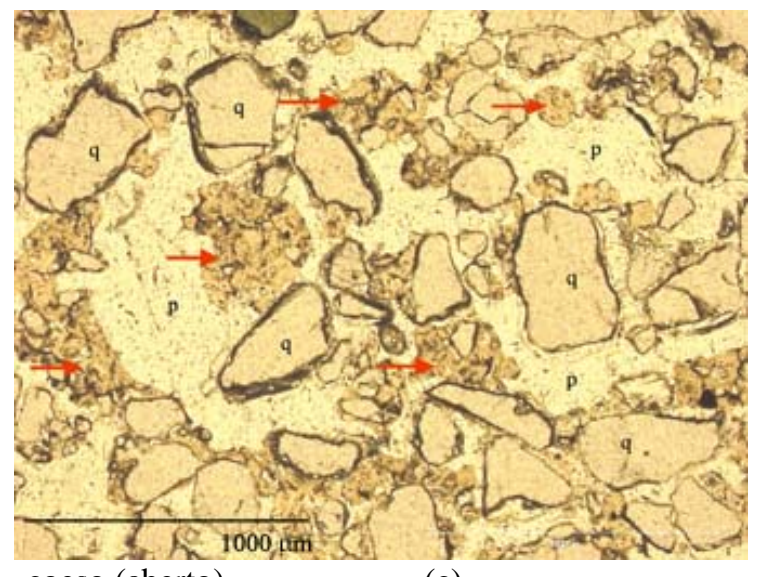
coeso (aberto) (c)

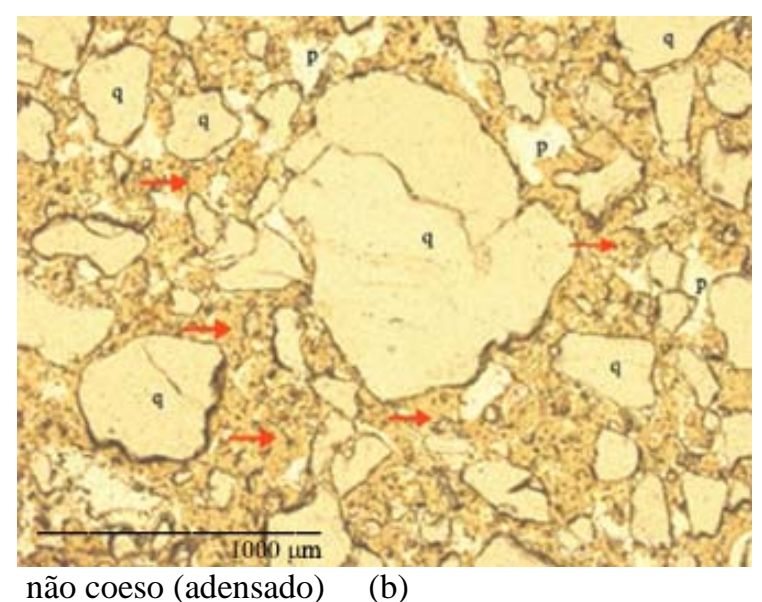

(b)

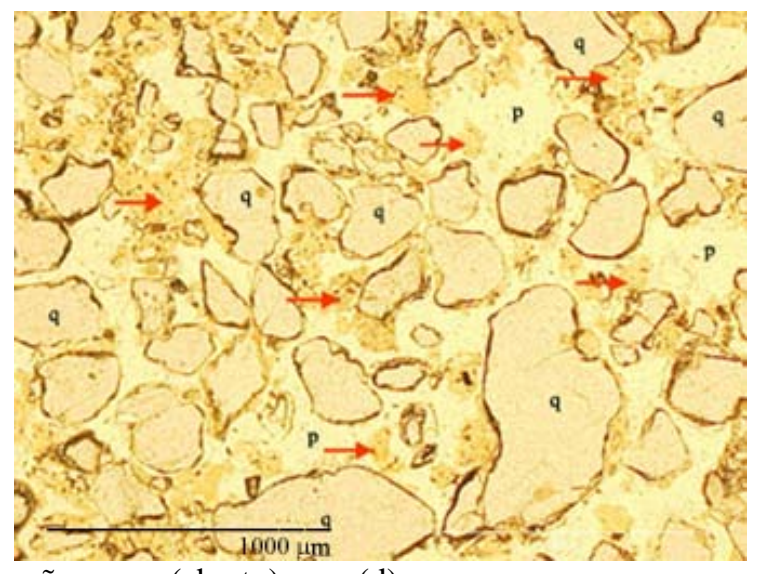

(d)

Figura 1 - Fotomicrografias das áreas adensadas e abertas do horizonte coeso (Bt1 coeso) e do não coeso (Bt1): a) mostra o predomínio de áreas com solo maciço (área adensada) onde os grãos de quartzo encontram-se totalmente imersos na fração fina do solo; b) área adensada do horizonte não coeso com presença de poros do tipo cavidades; c) área aberta do horizonte coeso mostrando microagregados arredondados isolados ou ligados uns aos outros; d) área aberta do horizonte não coeso mostrando uma rede de poros comunicantes, onde a fração fina encontra-se às vezes isolada ou ao redor dos grãos de quartzo. As setas vermelhas mostram a localização e o arranjamento da fração fina do solo. As letras indicam: q= quartzo e p=poro 


\subsubsection{Análise de imagens}

A Figura 2 mostra a distribuição espacial dos constituintes matriciais das áreas adensadas e abertas do horizonte coeso (Figura 2a,c) e do não coeso (Figura 2b,d). Notase uma grande variação em relação ao formato e arranjamento dos poros e da micromassa, entre as áreas adensadas dos dois horizontes. A matriz do horizonte coeso (Figura 2a) apresenta-se maciça (apedal). Os poros são pequenos e individualizados, sem comunicação entre eles. Já o horizonte não coeso (Figura 2b) apresenta nítida definição dos poros que se apresentam interconectados, acomodados e não acomodados, definindo os agregados e suas formas.

As fotomicrografias comprovam que o horizonte coeso é constituído por uma matriz predominantemente densa (Figura 2a), mas com partes abertas (Figura 2c) que possivelmente podem influenciar a tendência desses solos a formarem agregados quando úmidos. A Figura 2c evidencia que a grande diferença entre as áreas adensadas dos dois horizontes é a presença de poros grandes e interconectados no não coeso.

As características micromorfológicas apresentadas e as fotomicrografias indicam que à parte adensada do horizonte coeso é a grande responsável pelo aumento na densidade do solo e da resistência do solo à penetração, sendo que a área aberta do coeso também é mais densa e de menor porosidade que a do não coeso (Figura 2c,d).

A área adensada do horizonte coeso (Figura 2a) evidência a grande área de contato existente entre as suas partículas, o que atribui ao solo maior densidade (Capítulo 4). A maior fricção interpartículas favorece a atuação das forças mátricas do solo, que conferem ao mesmo um maior estresse efetivo durante o secamento, aumentando conseqüentemente a sua resistência (Mullins, 1999). Estudos realizados por Giarola et al. (2003) mostraram que a diferença nos dados de resistência à penetração entre solos coesos e não coesos foram devidas, principalmente, ao incremento do estresse efetivo e da resistência friccional entre os grãos. 


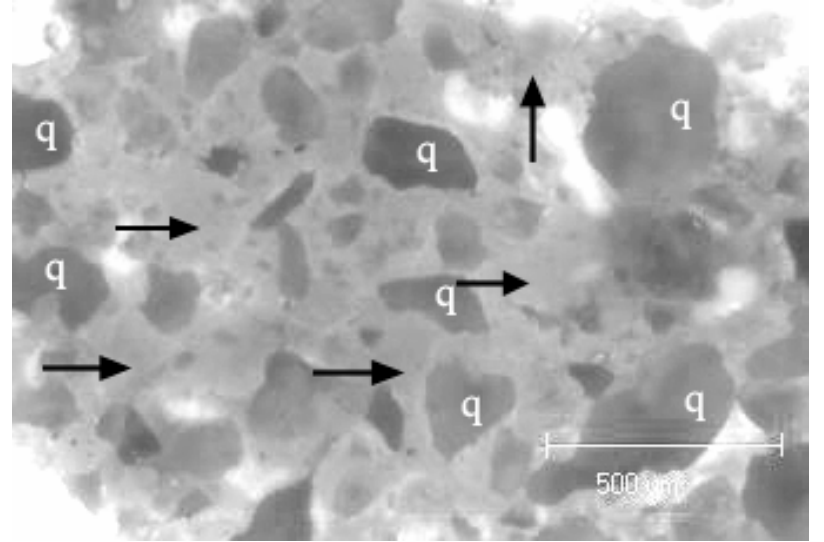

coeso (adensado)

(a)

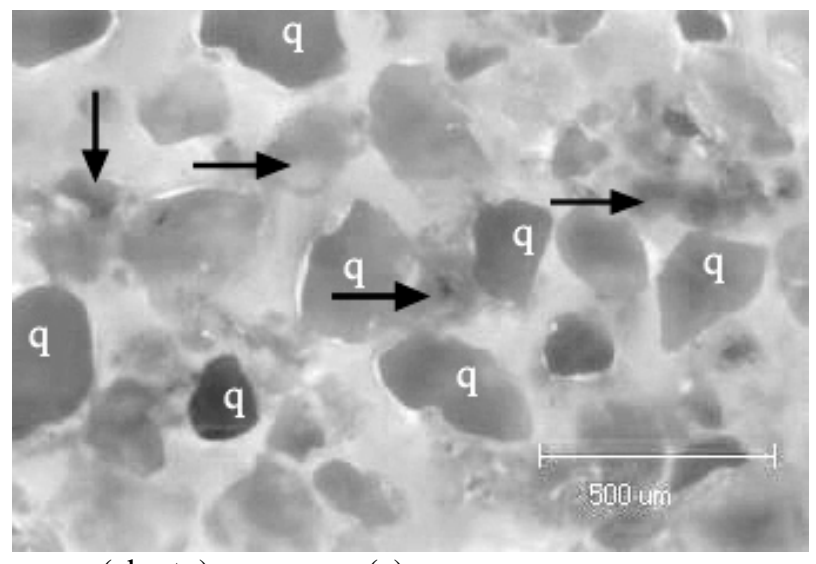

coeso (aberto)

(c)

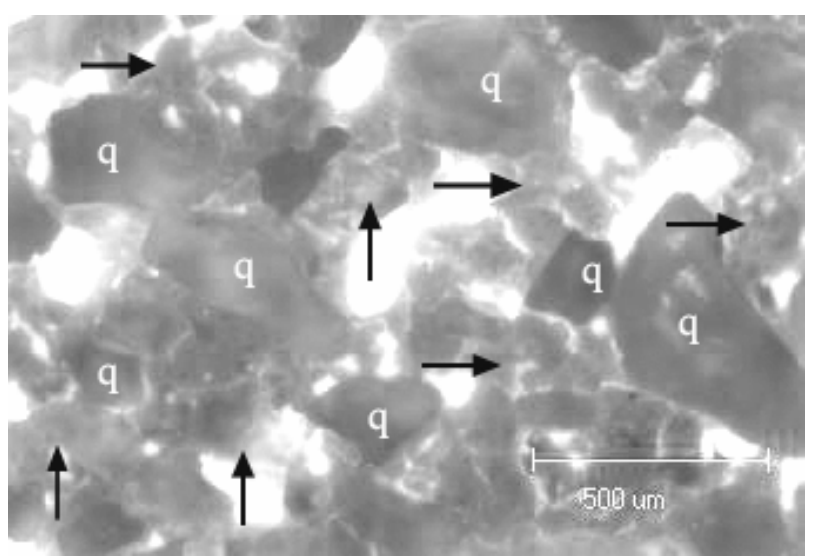

não coeso (adensado)

(b)

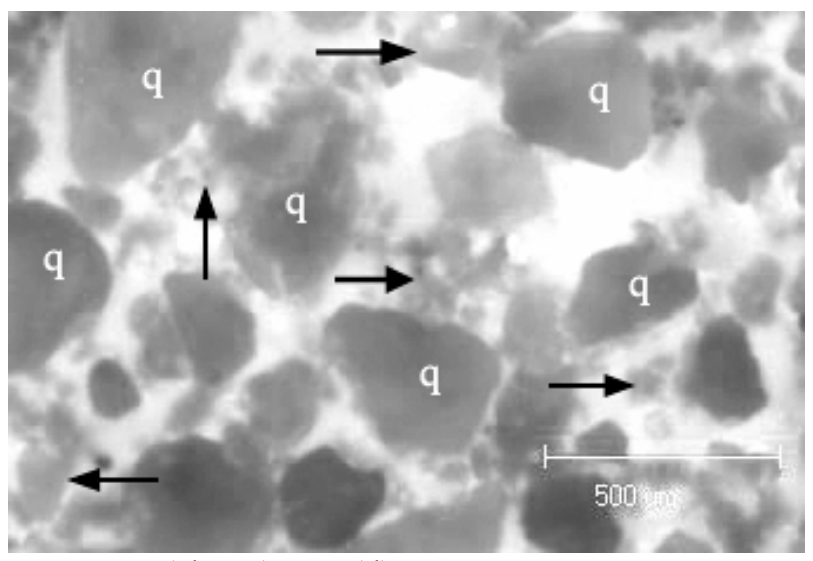

não coeso (aberto) (d)

Figura 2 - Fotomicrografias dos blocos, iluminadas com luz ultravioleta, nas áreas adensadas e abertas do horizonte coeso (Figura 2a,c) e do não coeso (Figura 2b,d). As setas mostram concentrações da fração fina do solo e q=quartzo

O aumento da área de contato entre as partículas, possibilita o aumento do estresse efetivo que mantém as partículas do solo mais unidas, quando seco (Giarola et al., 2003), como também favorece a formação de pontes, feitas por materiais finos como argila e silte, conectando os grãos de areia (Mullins et al., 1987), aumentando a resistência do solo quando seco.

Com base nos dados apresentados pode-se supor que o adensamento do horizonte coeso é atribuído, entre outros fatores, a maior área de contato existente entre as suas partículas. 
A porosidade total (PT) obtida por análise de imagens nas fotomicrografias dos blocos (Figura 3), mostra que não há diferença estatística entre as áreas abertas do horizonte coeso e do não coeso, as quais apresentam média e erro padrão de 36,54 \pm $1,18 \%$ e 38,73 $\pm 1,29 \%$, respectivamente, com P>0,2. Já a área adensada do horizonte coeso apresenta uma PT de 5,53 \pm 0,69 \%, sendo significativamente menor que a PT do não coeso (15,29 $\pm 1,29 \%$ ), com $\mathrm{P}<0,001$. Isso mostra que o adensamento natural que ocorre no horizonte coeso induz a uma redução do espaço poroso de 64\%, quando comparado com o não coeso (sob mata).

Estudos realizados por Giarola et al. (2003) em solos coesos mostraram uma redução do espaço poroso total, obtido por análise de imagens em lâminas delgadas, de apenas $18 \%$ quando comparado o horizonte coeso com o horizonte não coeso. Esta pequena redução do espaço poroso se dá em virtude do cálculo da PT ter considerado toda a superfície da lâmina. Esse fato, ressalta a importância de uma avaliação criteriosa do perfil antes da coleta do material para análise, já que alguns pontos podem não ser representativos da máxima coesão do solo. 


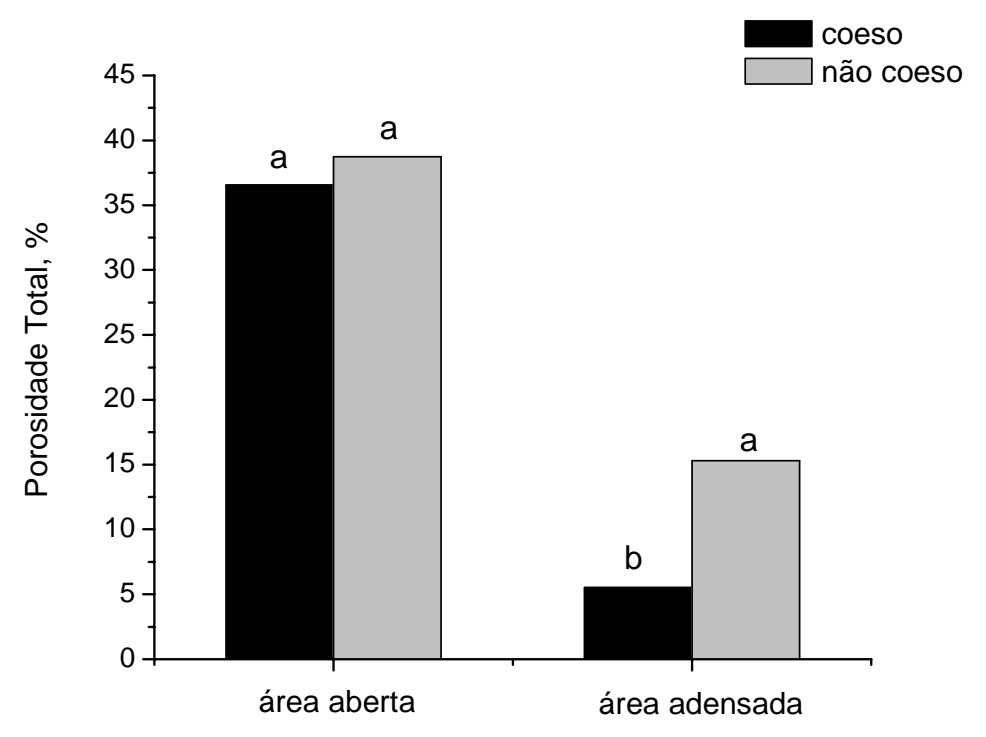

Figura 3 - Média da porosidade total do horizonte coeso (Bt1 coeso) e do não coeso (Bt1), determinada pela análise de imagem. Médias seguidas da mesma letra, nas colunas, não diferem entre si a $5 \%$ pelo teste de Tukey

A Figura 4 mostra a distribuição das classes de área dos poros na lâmina delgada, que abrange os microporos (intervalo menor que $\left.0,0007 \mathrm{~mm}^{2}\right)$, mesoporos $\left(0,0007 \mathrm{~mm}^{2}\right.$ $<$ intervalo de classe dos poros $>0,004 \mathrm{~mm}^{2}$ ) e macroporos (classes de tamanho maiores que 0,004 $\mathrm{mm}^{2}$ ) (Brewer, 1976; Luxmoore, 1981), sendo a classe mais detalhada neste estudo a dos macroporos e mesoporos, devido a área mínima de cada pixel na imagem ser igual a $125 \mu \mathrm{m}^{2}$.

Os macroporos ocupam 95,94 \% da porosidade total (PT) da lâmina na área aberta do horizonte coeso (Figura 4a) contra 96,82 \% do não coeso (Figura 4b), se destacando nos dois horizontes os poros com tamanhos superiores a $0,1 \mathrm{~mm}^{2}$. Os meso (3,44\% e $2,83 \%)$ e microporos ( $0,62 \%$ e $0,36 \%)$, respectivamente, no coeso e no não coeso, ocupam apenas uma pequena porção da PT.

Na área adensada há uma acentuada redução dos macroporos que passam a ocupar 69,73\% da porosidade total da lâmina no horizonte coeso (Figura 4c) e 82,15\% no não coeso (Figura 4d), essa diminuição acarreta um aumento na quantidade de meso 
(26,98\% e $14,93 \%)$ e microporos (3,28\% e 2,91\%), para o coeso e não coeso, respectivamente.

A redução da área ocupada pelos macroporos nas partes adensadas é acompanhada por igual redução no seu tamanho, os quais passam a adquirir uma distribuição unimodal (Figura 4c,d). Os macroporos com áreas superiores a 0,1 mm² desaparecem, predominando poros com intervalo de área entre 0,01 a $0,04 \mathrm{~mm}^{2}$ no horizonte coeso e 0,02 a $0,07 \mathrm{~mm}^{2}$ no não coeso.

Estatisticamente há diferença significativa quando se comparam as classes de poros entre a área aberta e fechada dos dois horizontes, com $\mathrm{P}=0,01$. Contudo, essa diferença não é observada quando são comparadas as classes de poros, entre as áreas adensadas dos horizontes: coeso e não coeso. Isso evidencia que o adensamento natural que ocorre no horizonte coeso é o grande responsável pelo aumento na coesão do solo.

A drástica redução dos macroporos na área adensada, pode estar relacionada a uma das hipóteses utilizadas para explicar a gênese dos horizontes coesos, na qual a sua formação é atribuída ao adensamento por dessecação, resultante da alteração da estrutura do solo e pela alternância de ciclos de umedecimento e secagem (Ribeiro, 1986 e Ponte \& Ribeiro, 1990). Esta hipótese se baseia no pressuposto de que, durante o período seco, os agentes cimentantes seriam desidratados e a matriz argilosa consolidada a ponto de promover o adensamento, e que, no período úmido, os agregados seriam destruídos devido ao aumento da pressão do ar no seu interior.

Com isso, pode-se supor que durante o período seco os planos de fraqueza observados no horizonte coeso, em condições de campo, provavelmente são atribuídos às áreas abertas presentes nesses solos.

Outro fator considerado para explicar a redução do espaço poroso, seria o adensamento natural do material que constitui os horizontes coesos, originando acúmulos de materiais finos e o arranjamento massivo das partículas, o que aumenta a quantidade de microporos, restringe a permeabilidade e favorece a precipitação dos agentes cimentantes temporários (Araújo Filho et al., 2001). 
A redução do volume de macroporos também influencia a redução na taxa de movimentação da água no solo e na circulação do ar, atribuindo efeitos marcantes na distribuição das raízes no solo (Cintra, 2001).

A maior quantidade de macroporos nas áreas adensadas do horizonte não coeso, conferem a este solo um arranjamento diferente e conseqüentemente melhor condições físicas para a penetração das raízes e para o movimento da água no solo, quando comparado com o horizonte coeso. Esses resultados confirmam a importância do arranjamento estrutural do solo na distribuição dos poros e, por conseqüência, na manifestação da coesão.

O detalhamento das classes de tamanho dos macroporos é muito importante para a determinação da estrutura do solo. No entanto, ressalta-se que a concentração de macroporos no horizonte coeso é pequena, quando comparado com a quantidade de microporos, determinados através de curva de retenção (Capítulo 4), existentes nas áreas adensadas. 


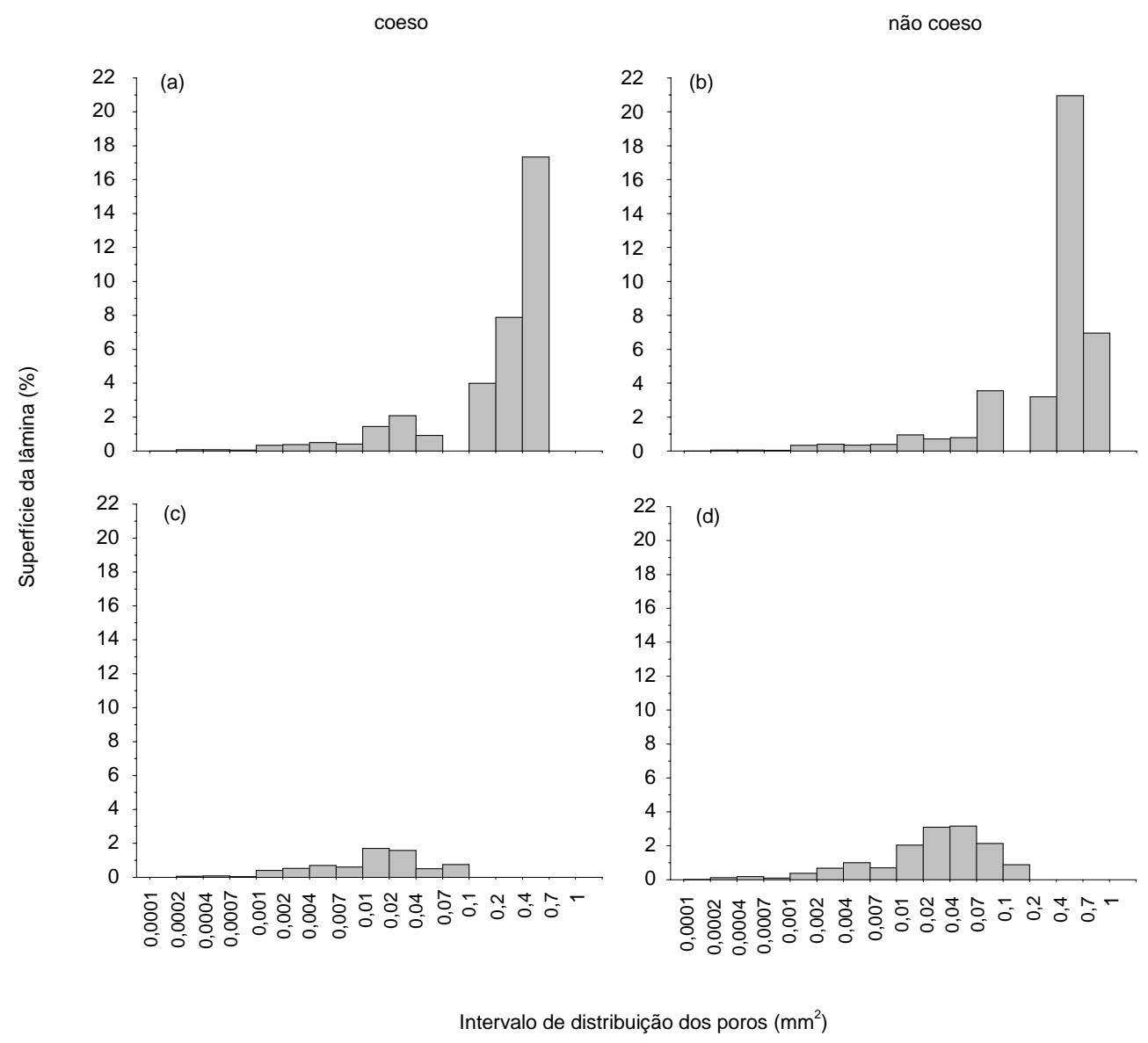

Figura 4 - Intervalo de distribuição da área dos poros em função da superfície da lâmina nas áreas abertas e adensadas do horizonte coeso (a, c) e, nas áreas abertas e adensadas do não coeso (b, d)

A Figura 5 mostra a mudança na morfologia e no tamanho dos poros entre as áreas abertas e adensadas. A distribuição dos poros em classes mostra o predomínio de poros grandes alongados e complexos na área aberta do horizonte coeso (Figura 5a) e do não coeso (Figura 5b), os quais ocupam juntos aproximadamente 79\% da PT no coeso e $85 \%$ no não coeso.

Curmi et al. (1994) estudando a degradação da estrutura em oxissolos submetidos a cultivo, mostraram que os poros intra-agregados (dentro dos agregados) não são 
afetados pelo processo de compactação, os inter-agregados (entre os agregados) têm seu tamanho e formato reduzido e os poros provenientes da atividade biológica, tipo canais, desaparecem quando submetidos a processos de compactação. Já Guérif (1990) define os poros intra-agregados como aqueles provenientes do espaço poroso textural, que ocorrem principalmente, devido ao empacotamento das partículas minerais do solo e, os poros inter-agregados são provenientes do espaço poroso estrutural, que resultam do arranjamento estrutural dos agregados ou grumos, e são criados pelo cultivo e/ou fissuramento natural.

A análise de imagem nas áreas adensadas mostra a mudança na morfologia e no tamanho dos poros no horizonte coeso (Figura 5c) e no não coeso (Figura 5d), onde os poros alongados (inter-agregados) têm seu volume reduzido e os poros complexos desaparecem completamente. O principal efeito do adensamento do solo parece ser a criação de poros arredondados médios $(>0,001$ e $\leq 0,01)$ e grandes $(>0,01)$, em decorrência da redução dos poros alongados e do desaparecimento dos complexos. O aumento dos poros arredondados grandes foi mais pronunciado no horizonte não coeso.

Observa-se que os poros arredondados pequenos $\left(\leq 0,001 \mathrm{~mm}^{2}\right)$, intra-agregados, não apresentam variação entre a área adensada (0,21\%) e aberta $(0,22 \%)$ do horizonte coeso (Figura 5a,c), mas no horizonte não coeso houve um aumento de 0,27\%, entre a área aberta (0,14\%) e a área adensada (0,41\%) (Figura 5b,d).

A menor quantidade de poros intra-agregados na área adensada do coeso, pode explicar a maior resistência tênsil encontrada nos agregados desse horizonte (Capítulo 4), já que, de acordo com Guérif (1990), a resistência tênsil pode ser definida como a resistência tênsil intra-agregado, que é medida em um pequeno volume de solo, resultante do empacotamento das partículas do solo.

Tais observações podem explicar o comprometimento causado pelo horizonte coeso no crescimento das raízes no solo, o qual é favorecido pela presença de poros largos. Rezende (2000) salientou o efeito negativo do aumento da resistência dos horizontes coesos no desenvolvimento do sistema radicular da laranjeira, sobretudo das raízes pivotantes. Com a predominância de áreas adensadas no horizonte coeso, as raízes não encontram caminhos para se desenvolverem devido à ausência de poros fissurais. 

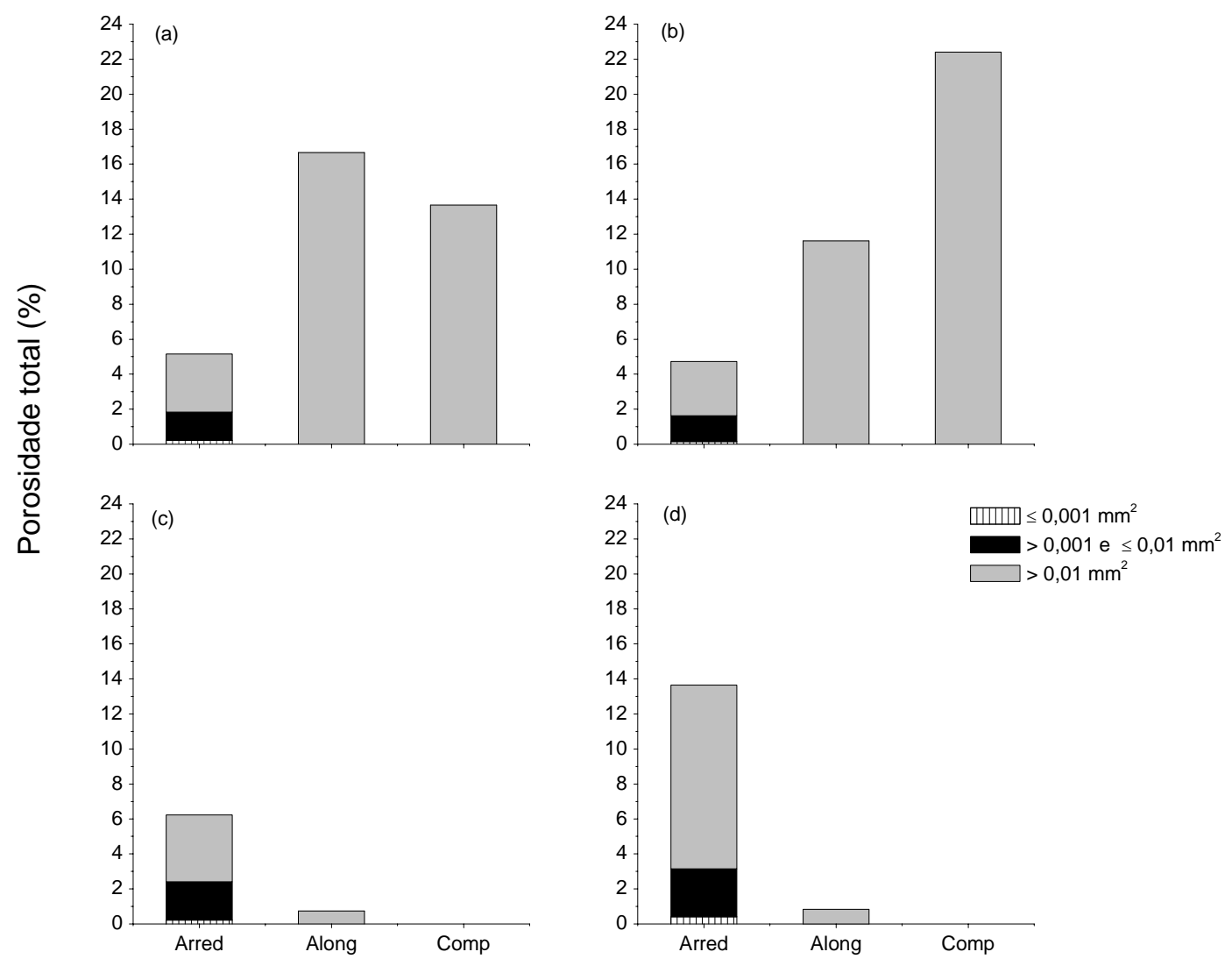

Figura 5 - Distribuição da porosidade total de acordo com a forma e o tamanho dos poros, nas áreas abertas e adensadas do horizonte coeso (a, c) e, nas áreas abertas e adensadas do não coeso (b, d). Arred.= arredondados, Along.= alongados e Comp. $=$ complexos

A porcentagem de poros alongados existentes nas áreas adensadas dos dois horizontes, não apresentou diferença estatística entre si, com média de 0,73\% no coeso (Figura 5c) e 0,83\% no não coeso (Figura 5d), com P>0,1. Com base nisso, e considerando que os poros alongados são influenciados pelo adensamento do solo (Murphy et al., 1977), os mesmos foram utilizados para determinar a orientação preferencial dos poros nas áreas abertas e adensadas do horizonte coeso (Figura 6a,c) e do não coeso (Figura 6b,d). 
Observa-se que as áreas abertas dos dois horizontes não apresentam uma orientação preferencial (Figura 6a,b). Contudo, a área adensada do horizonte coeso (Figura 6c) possui uma forte orientação preferencial dos poros alongados, os quais tendem para a horizontal. Este resultado indica uma continuidade horizontal desses poros e explica o fluxo preferencial da água.

A análise de imagens mostra a mudança na morfologia, no tamanho e na orientação dos poros sofrida na área adensada do horizonte coeso, o que restringe o movimento descendente da água no solo, devido à predominância de poros pequenos e a orientação preferencialmente horizontal dos poros alongados. Este fato explica a baixa condutividade hidráulica saturada encontrada nos horizontes coesos (Santos, 1992 e Nacif, 1994), já que o movimento da água no solo em condições saturadas é afetado pelos macroporos e depende principalmente da sua morfologia (Bouma, 1981; Germann \& Beven, 1981; Douglas, 1986).

Resultados apresentados por Hallaire \& Curmi (1994) mostram que o fluxo de transferência da água no solo é determinado mais pela forma do que pelo tamanho dos macroporos. 

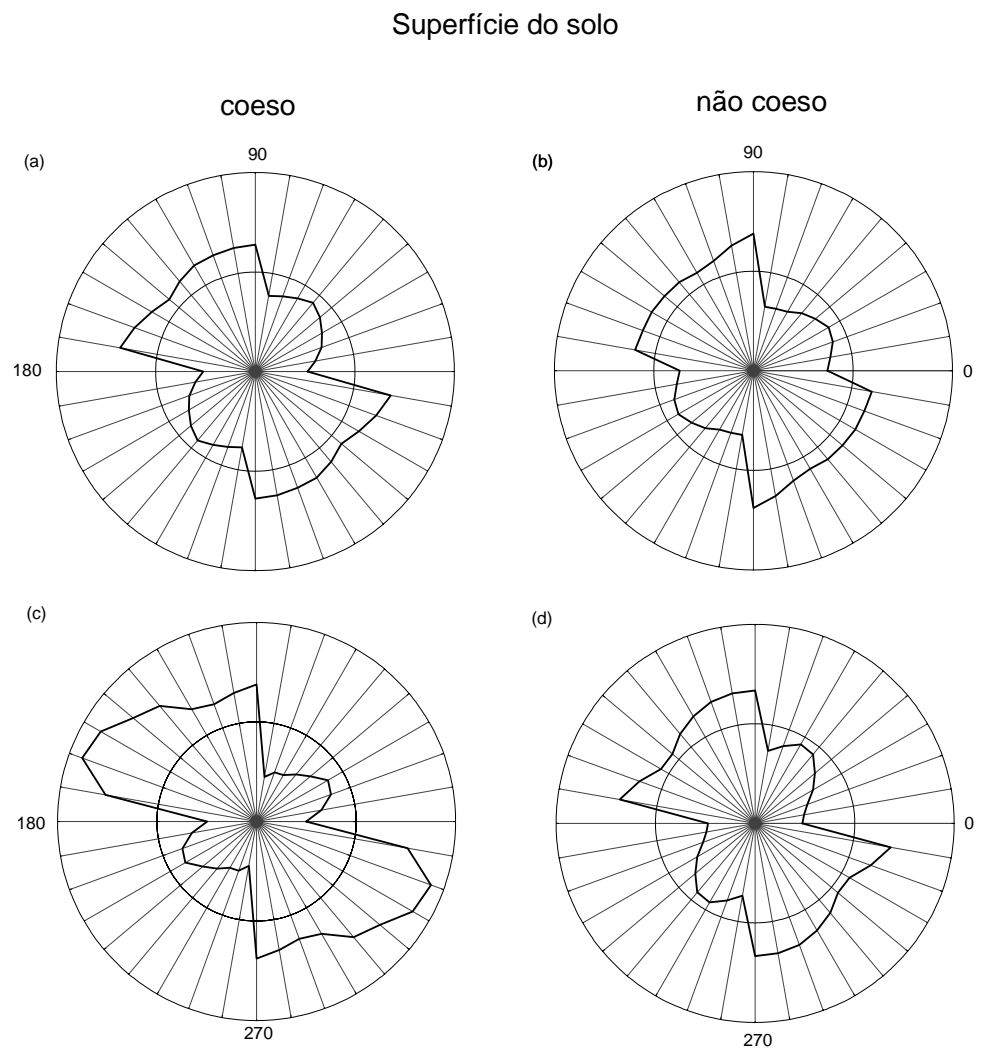

Figura 6 - Orientação média (relação entre os diâmetros horizontais e verticais de Feret) dos poros alongados, nas áreas abertas e adensadas do horizonte coeso (a,c) e, nas áreas abertas e adensadas do não coeso (b,d)

\subsection{Conclusão}

O trabalho confirmou a hipótese de que o adensamento natural existente nos horizontes coesos além de influenciar na quantidade de poros, também influencia o seu formato e sua orientação.

As áreas adensadas, medidas por análise de imagem, no horizonte coeso foram os principais fatores que influenciaram o espaço poroso do solo, sendo responsável pelo aumento da sua resistência. 


\section{CONCLUSÕES GERAIS}

Os resultados obtidos confirmaram a hipótese de que há ocorrência de solos coesos no Estado do Ceará, os quais apresentam características morfológicas semelhantes às encontradas em outros solos pertencentes aos Tabuleiros Costeiros, além das mesmas restrições físicas e químicas.

Os valores de resistência tênsil, resistência do solo à penetração e densidade do solo, mostraram-se mais elevados no solo coeso do Ceará do que em outros solos pertencentes aos Tabuleiros Costeiros estudados no Brasil.

O adensamento natural existente nos horizontes coesos além de influenciar na quantidade dos poros, também influencia o seu tamanho, formato e a sua orientação, ou seja, há predominância de poros pequenos, arredondados e com orientação horizontal.

As áreas adensadas encontradas no horizonte coeso foram os principais fatores que influenciaram o espaço poroso do solo, sendo responsável pelo aumento na resistência do solo. 


\section{REFERÊNCIAS BIBLIOGRÁFICAS}

ABRAHÃO, W.A.P.; COSTA, L.M.; MELLO, J.W.V.; NEVES, J.C.L. Distribuição de freqüência de tamanho da fração areia e compacidade relativa de solos desenvolvidos de sedimentos do Grupo geológico Barreiras. Revista Brasileira de Ciência do Solo, v.22, p.1-9, 1998.

ANJOS, L.H.C. Caracterização, gênese, classificação e aptidão agrícola de uma seqüência de solos do Terciário na região de Campos. Itaguaí, 1985. 194p. Dissertação (Mestrado) - Universidade Federal Rural do Rio de Janeiro.

ARAUJO FILHO, J.C.; CARVALHO, A.; SILVA, F.B.R. Investigações preliminares sobre a pedogênese de horizontes coesos em solos dos tabuleiros costeiros do Nordeste do Brasil. In: WORKSHOP COESÃO EM SOLOS DOS TABULEIROS COSTEIROS, Aracaju, 2001. Anais. Aracaju: EMBRAPA Tabuleiros Costeiros, 2001. p.123-142.

BIGARELLA, J.J. The Barreiras Group in Northeastern Brazil. Anais da Academia Brasileira de Ciências, v.47, p.365-393, 1975. Suplemento.

BLAKE, G.R.; HARTGE, K.H. Bulk density. In: KLUTE, A. (Ed.). Methods of soil analysis. 2 ed. Madison: SSSA, 1986. Part 1: Physical and mineralogical methods, p.363-375.

BOUABID, R.; NATER E.A.; BARAK, P. Measurements of pore size distribution in a lamellar Bt horizon using epifluorescence microscopy and image analysis. Geoderma, v.53, p.309-328, 1992.

BOUMA, J. Soil micromorphology and preferential flow along macropores. Agricultural Water Management, v.3, p.235-250, 1981. 
BOUMA, J.; JONGERIUS, A.; BOERSMA, O.; JAGER, A.; SCHOONDERBEEK, D. The function of different types of macropores during satured flow through four swelling soil horizons. Soil Science Society of America Journal, v.41, p.945-950, 1977.

BREWER, R. Fabric and mineral analysis of soils. New York: Robert E. Krieger, 1976. 482p.

CAUSARANO, H. Factors affecting the tensile strength of soil aggregates. Soil \& Tillage Research, v.28, p.15-25, 1993.

CHARTRES, C.J.; NORTON, L.D. Micromorphology na chemical properties of Australian soil with hardsetting and duric horizons. In: WORKING MEETING ON SOIL MICROMORPHOLOGY, 9., Townsville, 1992. Soil micromorphology: studies in management and genesis; proceedings, edited by A.J. Ringrose-Voase, and G.S. Humpheys. Amsterdam: Elsevier, 1994. p.825-834. (Developments in Soil Science, 22).

CINTRA, F.L.D. Distribuição do sistema radicular na presença de horizontes coesos. In: WORKSHOP COESÃO EM SOLOS DOS TABULEIROS COSTEIROS, Aracaju, 2001. Anais. Aracaju: EMBRAPA Tabuleiros Costeiros, 2001. p.229239.

CINTRA, F.L.D.; LIBARDI, P.L. Caracterização física de uma classe de solo do ecossistema do Tabuleiro Costeiro. Scientia Agricola, v.55, p.367-378, 1998.

CINTRA, F.L.D.; LIBARDI, P.L.; SILVA, A.P. Tabuleiros Costeiros do Nordeste do Brasil: uma análise dos efeitos do regime hídrico e da presença de camadas coesas nos solos. Boletim Informativo da Sociedade Brasileira de Ciência do Solo, v.22, p.77-80, 1997.

COOPER, M. Influência das condições físico-hídricas nas transformações estruturais entre horizontes B latossólico e B textural sobre diabásio. Piracicaba, 1999. 130p. Tese (Doutorado) - Escola Superior de Agricultura “Luiz de Queiroz”, Universidade de São Paulo. 
CURMI, P.; KERTZMAN, F.F.; QUEIROZ NETO, J.P. Degradation of structure and hydraulic properties in an Oxisol under cultivation (Brazil). In: WORKING MEETING ON SOIL MICROMORPHOLOGY, 9., Townsville, 1992. Soil Micromorphology: studies in management and genesis; proceedings, edited by A.J. Ringrose-Voase and G.S. Humpheys, Amsterdam: Elsevier, 1994. p.569-579. (Developments in Soil Science, 22).

DEEKS, L.K.; WILLIAMS, A.G.; DOWD, J.F.; SCHOLEFIELD, D. Quantification of pore size distribution and the movement of solutes through isolated soil blocks. Geoderma, v.90, p.65-86, 1999.

DEMATTÊ, J.L.I.; MAZZA, J.A.; DEMATTÊ, J.A.M. Caracterização e gênese de uma topossequência Latossolo Amarelo-Podzol originado de material da Formação Barreiras - Estado de Alagoas. Scientia Agricola, v.53, p.20-30, 1996.

DEXTER, A.R.; KROESBERGEN, B. Methodology for determination of tensile strength of soil aggregates. Journal of Agricultural Engineering Research, v.31, p.139-147, 1985.

DEXTER, A.R.; WATTS, C.W. Tensile strength and friability. In: SMITH, K.A.; MULLINS, C.E. (Ed.). Soil and environmental analysis: physical Methods. 2.ed. New York: Marcel Dekker, 2000. p.401-430.

DOUGLAS, J.T. Macroporosity and permeability of some soil core from England and France. Geoderma, v.37, p.221-231, 1986.

DUARTE, M.N.; CURI, N.; PÉREZ, D.V.; KÄMPF, N.; CLAESSEN, M.E.C. Mineralogia, química e micromorfologia de solos de uma microbacia nos Tabuleiros Costeiros do Espírito Santo. Pesquisa Agropecuária Brasileira, v.35, n.6, p.12371250, 2000.

EMPRESA BRASILEIRA DE PESQUISA AGROPECUÁRIA. Centro Nacional de Pesquisa de Solos. Manual de métodos e análise de solo. 2. ed. Rio de Janeiro, 1997. 212p.

EMPRESA BRASILEIRA DE PESQUISA AGROPECUÁRIA. Centro Nacional de Pesquisa de Solos. Sistema brasileiro de classificação de solos. Rio de Janeiro, 1999. 412p. 
FERREIRA, M.M.; FERNANDES, B.; CURI, N. Influência da mineralogia da fração argila nas propriedades físicas de Latossolos da região Sudeste do Brasil. Revista Brasileira de Ciência do Solo, v.23, p.515-524, 1999a.

FERREIRA, M.M.; FERNANDES, B.; CURI, N. Mineralogia da fração argila e estrutura de Latossolos da região Sudeste do Brasil. Revista Brasileira de Ciência do Solo, v.23, p.507-514, 1999 b.

FLINT, A.L.; FLINT, L.E. Particle density. In: DANE, J.H.; TOPP, G.C. (Ed.). Methods of soil analysis. Madison: SSSA, 2002. Part 4: Physical methods. p.235240.

FONSECA, O.O.M. Caracterização e classificação de solos latossólicos e podzólicos desenvolvidos nos sedimentos do Terciário no litoral brasileiro. Itaguaí, 1986. 185p. Dissertação (Mestrado) - Universidade Federal Rural do Rio de Janeiro.

GEE, G.W.; BAUDER, J.W. Particle-size analysis. In: KLUTE, A. (Ed.). Methods of soil analysis: physical and mineralogical methods. Madison: SSSA, 1986. p.383409.

GERMANN, P.; BEVEN, K. Water flow in soil macropores. I. An experimental approach. Journal of Soil Science, v.32, p.1-13, 1981.

GIAROLA, N.F.B.; SILVA, A.P. Conceitos sobre solos coesos e hardsetting. Scientia Agricola, v.59, p.613-620, 2002.

GIAROLA, N.F.B.; SILVA, A.P.; IMHOFF, S.; DEXTER, A.R. Contribution of natural soil compaction on hardsetting behavior. Geoderma, v.113, p.95-108, 2003.

GIAROLA, N.F.B.; SILVA, A.P.; TORMENA, C.; SOUZA, L.S.; RIBEIRO, L.P. Similaridades entre o caráter coeso dos solos e o comportamento hardsetting: estudo de caso. Revista Brasileira de Ciência do Solo, v.25, p.239-247, 2001.

GUÉRIF, J. Factors influencing compaction-induced increases in soil strength. Soil \& Tillage Research, v.16, p.167-178, 1990.

GUERRA, A.T. Dicionário geológico - geomorfológico. 5.ed. Rio de Janeiro: IBGE, 1978. 448p. (Biblioteca Geográfica Brasileira. Série A, 20). 
GUSLI, S.; CASS, A.; MACLEOD, D.A.; BLACKWELL, P.S. Structural collapse and strength of some Australian soils in relation to hardsetting: II. Tensile strength of collapsed aggregates. European Journal of Soil Science, v.45, p.23-29, 1994.

HALLAIRE, V; CURMI, P. Image analysis of pore space morphology in soil sections, in relation to water movement. In: WORKING MEETING ON SOIL MICROMORPHOLOGY, 9., Townsville, 1992. Soil Management: studies in management and genesis; proceedings, edited by RINGROSE-VOASE, A.J. and HUMPHEYS, G.S. Amsterdam: Elsevier, 1994. p.559-567. (Developments in Soil Science, 22).

IMHOFF, S.; SILVA, A.P.; DEXTER, A. Factors contributing to the tensile strength and friability of oxisols. Soil Science Society of America Journal, v.66, p.16561661, 2002.

JACKSON, M.L. Soil chemical analysis: advance course. Madison: Prentice-Hall, 1979. 895p.

JACOMINE, P.K.T. Distribuição geográfica, característica e classificação dos solos coesos dos Tabuleiros Costeiros. In: REUNIÃO TÉCNICA SOBRE SOLOS COESOS DOS TABUlEIROS COSTEIROS, Cruz das Almas, 1996. Anais. Aracaju: EMBRAPA-CPATC; CNPMF; EAUFBA; IGUFBA, 1996. p.13-26.

JACOMINE, P.K.T. Evolução do conhecimento sobre solos coesos no Brasil. In: WORKSHOP COESÃO EM SOLOS DOS TABULEIROS COSTEIROS, Aracaju, 2001. Anais. Aracaju: EMBRAPA Tabuleiros Costeiros, 2001. p.19-46.

JACOMINE, P.K.T.; ALMEIDA, J.C.; MEDEIROS, L.A.R. Levantamento exploratório-reconhecimento de solos do Estado do Ceará. Recife: EMBRAPA, DPP, SUDENE, 1973. 2v. 830p. (Boletim Técnico, 28; Série Pedologia, 16).

JONGERIUS, A.; HEINTZBERGER, G. Methods in soil micromorphology: a technique for the preparation of large thin sections. Wageningen: Soil Survey Institute, 1975. 48p. (Soil Survey Papers, 10).

KLUTE, A. Water retention: laboratory methods. In: KLUTE, A. (Ed.). Methods of soil analysis. 2. ed. Madison: ASA-SSSA, 1986. Part 1: Physical and mineralogical methods, p.635-660. 
LEMOS, R.C.; SANTOS, R.D. Manual de descrição e coleta de solos no campo. 3. ed. Campinas: SBCS, 1996. 45p.

LEY, G.J.; MULLINS, C.E.; LAL, R. Hard-setting behaviour of some structurally weak tropical soils. Soil \& Tillage Research, v.13, p.365-381, 1989.

LEY, G.J.; MULLINS, C.E.; LAL, R. The potential restriction to root growth in structurally weak Tropical soils. Soil \& Tillage Research, v.33, p.133-142, 1995.

LINDBO, D.L.; VENEMAN, P.L. Morphological and physical properties of selected fragipan soils in Massachusetts. Soil Science Society of America Journal, v.57, p.429-436, 1993.

LUXMOORE, R.J. Micro-, meso-, and macroporosity of soil. Soil Science Society of America Journal, v.45, p.671-672, 1981.

MEIRELES, M.C.S.; RIBEIRO, L.P. Caracterização da sílica em horizontes coesos de solos de Tabuleiro. In: CONGRESSO BRASILEIRO DE CIÊNCIA DO SOLO, 25., Viçosa, 1995. Anais. Viçosa: SBCS, 1995. p.1888-1889.

MELO, F.J.R.; SANTOS, M.C. Micromorfologia e mineralogia de dois solos de Tabuleiros Costeiros de Pernambuco. Revista Brasileira de Ciência do Solo, v.20, p.99-108, 1996.

MELO, J.O. Levantamento dos solos da estação experimental de Pacajus, CE. Fortaleza: UFC; SUDEC, 1968. 33p.

MERMUT, A.R. Introduction to soil micromorphology. Saskatoon: University of Saskatchewan, Department of Soil Science, 1992. 115p.

MOREAU, A.M.S.S. Gênese, mineralogia e micromorfologia de horizontes coeso, fragipã e duripã em solos do tabuleiro costeiro no sul da Bahia. Viçosa, 2001. 138p. Tese (Doutorado) -Universidade Federal de Viçosa.

MULLINS, C.E. Hardsetting. In: LAL, R.; BLUM, W.R.; VALENTINE, C.; STEWART, B.A. (Ed.). Methods for assessment of soil degradation. New York: CRC Press, 1997. p.109-128. (Advances in Soil Science, 19).

MULLINS, C.E. Hardsetting soil. In: SUMMER, M.E. (Ed.). Handbook of soil science. New York: CRC Press, 1999. p.G65-G87. 
MULLINS, C.E.; PANAYIOTOPOULOS, K.P. The strength of unsaturated mixture of sand and kaolin and the concept of effective stress. Journal of Soil Science, v.35, p.459-468, 1984.

MULLINS, C.E.; YOUNG, I.M.; BENGHOUGH, A.G.; LEY, G.J. Hard-setting soils. Soil Use and Management. v.3, p.79-83, 1987.

MULLINS, C.E.; CASS, A.; MACLEOD, D.A.; HALL, D.J.M.; BLACKWELL, P.S. strength development during drying of cultivated, flood-irrigated hardsetting soil. II. Trangie soil, and comparison with theoretical predictions. Soil \& Tillage Research, v.25, p.129-147, 1992.

MUNKHOLM, L.J.; SCHJØNNING, P.; KAY, B.D. Tensile strength of soils cores in relation to aggregate strength, soil fragmentation and pore characteristics. Soil \& Tillage Research, v.64, p.125-135, 2002.

MURPHY, C.P. Thin section preparation of soils and sediments. Berkhamsted: AB Academic Publishers, 1986. 149p.

MURPHY, C.P.; BULLOCK, P.; BISWELL, K.J. The measurement and characterisation of voids in soil thin sections by image analysis. Part II. Applications. Journal of Soil Science, v.28, p.509-518, 1977.

NACIF, P.G.S. Efeitos da subsolagem em propriedades físico-hídricas de um Latossolo Amarelo álico coeso, representativo do Recôncavo Baiano. Viçosa, 1994. 75p. Dissertação (Mestrado) - Universidade Federal de Viçosa.

NIELSEN, D.R.; BIGGAR, J.W.; ERH, K.T. Spacial variability of soil water properties. Hilgardia, v.42, p.215-259, 1973.

PAIVA, A.Q.; SOUZA, L.S.; RIBEIRO, A.C.; COSTA, L.M. Disponibilidade de água em uma topossequência de solos de tabuleiro do Estado da Bahia e sua relação com indicadores do crescimento da laranjeira. Revista Brasileira de Ciência do Solo, v.22, p.367-377, 1998.

PERFECT, E.; KAY, B.D.; DA SILVA, A.P. Influence of soil properties on the statistical characterization of dry aggregate strength. Soil Science Society of America Journal, v.59, p.532-537, 1995. 
PONTE, C.M.; RIBEIRO, L.P. Estudo da gênese de horizontes coesos em uma toposseqüência na área do Candeal - Escola de Agronomia da UFBA. Salvador: IGEO, UFBA, 1990.

PORTELA, J.C. Retenção da água em solo sob diferentes usos no ecossistema Tabuleiros Costeiros. Piracicaba, 2000. 53p. Dissertação (Mestrado) - Escola Superior de Agricultura “Luiz de Queiroz” - Universidade de São Paulo.

PROTZ, R.; SHIPITALO, M.J.; MERMUT, A.R. Image analysis of soil - present and future. Geoderma, v.40, p.115-125, 1987.

RAIJ, B. van; VALADARES, J.M.A.S. Análises dos elementos maiores de rochas, argilas e solos. Campinas: IAC, 1979. 23p. (Boletim Técnico, 16).

RAMOS, A.D.; OLIVEIRA, F.N.S. Recomendações técnicas para o manejo de solos cultivados com cajueiro no Ceará e Piauí. Fortaleza: EMBRAPA, CNPCA, 1993, 2p. (Comunicado Técnico, 4).

RESENDE, M. Aplicações de conhecimentos pedológicos à conservação de solos. Informe Agropecuário, v.11, p.3-18, 1985.

RESENDE, M.; CARVALHO FILHO, A.; LANI, J.L. Características do solo e da paisagem que influenciam a susceptibilidade à erosão. In: SIMPÓSIO SOBRE MANEJO E CONSERVAÇÃO DO SOLO NO CERRADO, 1., Campinas, 1992. Anais. Campinas: Fundação Cargill, 1992. p.32-67.

REUNIÃO TÉCNICA SOBRE SOLOS COESOS DOS TABULEIROS COSTEIROS.

Pesquisa e desenvolvimento para os tabuleiros costeiros. Cruz das Almas: UFBA; EAUFBA; IGUFBA; CNPMF; Aracaju: CPATC, 1996. 41p. (Guia de Excursão).

REZENDE, J.O. Solos coesos dos tabuleiros costeiros: limitações agrícolas e manejo. Salvador: SEAGRI, SPA, 2000. 117 p. (Série Estudos Agrícolas, 1).

REZENDE, J.O.; MAGALHÃES, A.F.J.; SHIBATA, R.T.; ROCHA, E.S.; FERNANDES, J.C.; BRANDÃO, F.J.C.; REZENDE, V.J.R.P. Citricultura nos solos coesos dos tabuleiros costeiros: análise e sugestões. Salvador: SEAGRI, SPA, 2002. 94p. (Série Estudos Agrícolas, 3). 
RIBEIRO, L.P. Sílica em horizontes coesos de solos da Bahia. Universitas, v.38, p.5980, 1986.

RIBEIRO, L.P. Premiers resultas sur la génese des sols a horizons indures dans la region du Cruz das Almas, BA, Brézil. In: TABLE RONDE SUR LÓRGANIZATION ET DINAMIQUE INTERNE DE LA COUVERTURE PEDOLOGIQUE, Caen, 1991. Anais. Caen: CNRS, 1991. 1v.

RIBEIRO, L.P. Gênese, evolução e degradação dos solos amarelos coesos dos Tabuleiros Costeiros. In: REUNIÃO TÉCNICA SOBRE SOLOS COESOS DOS TABULEIROS COSTEIROS, Cruz das Almas, 1996. Anais. Aracaju: EMBRAPA, CPATC; CNPMF; EAUFBA; IGUFBA, 1996. p.27-35.

RIBEIRO, L.P. Os Latossolos Amarelos do Recôncavo Baiano: gênese, evolução e degradação. Salvador: Seplantec, CADCT, 1998. 99p.

RIBEIRO, L.P. Evolução da cobertura pedológica dos tabuleiros costeiros e a gênese dos horizontes coesos. In: WORKSHOP COESÃO EM SOLOS DOS TABULEIROS COSTEIROS, Aracaju, 2001. Anais. Aracaju: EMBRAPA Tabuleiros Costeiros, 2001. p.93-121.

RIBEIRO, M.R. Características morfológicas dos horizontes coesos dos solos dos Tabuleiros Costeiros. In: WORKSHOP COESÃO EM SOLOS DOS TABULEIROS COSTEIROS, Aracaju, 2001. Anais. Aracaju: EMBRAPA Tabuleiros Costeiros, 2001. p.161-168.

RINGROSE-VOASE, A.J. A scheme for the quantitative description of soil macrostruture by image analysis. Journal of Soil Science, v.38, p.343-356, 1987.

RINGROSE-VOASE, A.J. Micromorphology of soil structure: description, quantification, application. Australian Journal of Soil Research, v.29, p.777-813, 1991.

SANTANA, M.B. Atributos físicos do solo e distribuição do sistema radicular de citros como indicadores da coesão em dois solos dos Tabuleiros Costeiros do Estado da Bahia. Viçosa, 2002. 73p. Dissertação (Mestrado) - Universidade Federal de Viçosa. 
SANTOS, D.M.B. Efeitos da subsolagem mecânica sobre a estrutura de um solo de “tabuleiro” (Latossolo amarelo álico coeso) no município de Cruz das Almas Bahia (Caso 2). Salvador, 1992. 78p. Dissertação (Mestrado) - Universidade Federal da Bahia.

SANTOS, M.C. Estudos micromorfológicos aplicados à avaliação da coesão em solos. In: WORKSHOP COESÃO EM SOLOS DOS TABULEIROS COSTEIROS, Aracaju, 2001. Anais. Aracaju: EMBRAPA Tabuleiros Costeiros, 2001. p.67-91.

SANTOS, M.C.; SILVA, M.S.L.; ALMEIDA, B.G.; KLAMT, E.; CAVALCANTI, A.C. Caracterização micromorfológica e considerações sobre a gênese de solos de Tabuleiro do semi-árido do Brasil. Revista Brasileira de Ciência do Solo, v.26, p.1031-1046, 2002.

SILVA, A.J.N.; RIBEIRO, M.R.; MERMUT, A.R.; BENKE, M.B. Influência do cultivo contínuo da cana de açúcar em Latossolos Amarelos coesos do Estado de Alagoas: propriedades micromorfológicas. Revista Brasileira de Ciência do Solo, v.22, p.515-525, 1998.

SILVA, A.P.; KAY, B.D.; PERFECT, E. Management versus inherent soil properties effects on bulk density and relative compaction. Soil \& Tillage Research, v.44, p.81-93, 1997.

SILVA, F.B.R.; RICHÉ, G.R.; TONNEAU, J.P.; SOUZA NETO, N.C.; BRITO, L.T.L.; CORREIA, R.C.; CAVALCANTI, A.C.; SILVA, F.H.B.B.; SILVA, A.B.; ARAUJO FILHO, J.C. Zoneamento agroecológico do nordeste: diagnóstico do quadro natural e agrossocioeconômico. Recife: EMBRAPA, CPATSA; EMBRAPA, CNPS, 1993. 2v.

SILVA, M.S.L. Efeito do cultivo da cana-de-açúcar em propriedades do solo de Tabuleiro do Estado de Alagoas. Recife, 1989. 106p. Dissertação (Mestrado) Universidade Federal Rural de Pernambuco.

SILVA, M.S.L.; RIBEIRO, M.R. Influência do cultivo contínuo da cana-de-açúcar em propriedades morfológicas e físicas de solos argilosos de tabuleiro no Estado de Alagoas. Revista Brasileira de Ciência do Solo, v.16, p.397-402, 1992. 
SMITH, C.W.; JOHNSTON, M.A.; LORENTZ, S. The effect of soil compaction and soil physical properties on the mechanical resistance of South African forestry soils. Geoderma, v.78, p.93-111, 1997.

SORT, X.; ALCAÑIZ, J.M. Modification of soil porosity after application of sewage sludge. Soil \& Tillage Research, v.49, p.337-345, 1999.

SOUZA, L.S. Uso e manejo dos solos coesos dos Tabuleiros Costeiros. In: REUNIÃO TÉCNICA SOBRE SOLOS COESOS DOS TABULEIROS COSTEIROS, Cruz das Almas, 1996. Anais. Aracaju: EMBRAPA, CPATC; CNPMF; EAUFBA; IGUFBA, 1996. p.36-75.

SOUZA, L.S. Aspectos sobre o uso e manejo dos solos coesos dos Tabuleiros Costeiros. Boletim Informativo da Sociedade Brasileira de Ciência do Solo, v.22, p.34-39, 1997.

SOUZA, L.S.; CALDAS, R.C.; SOUZA, L.D. Classes de coesão para solos de Tabuleiros Costeiros (compact disc). In: CONGRESSO BRASILEIRO DE CIÊNCIA DO SOLO, 29, Ribeirão Preto, 2003. Anais. Ribeirão Preto: SBCS; Jaboticabal: UNESP, 2003.

SOUZA, L.S.; SOUZA, L.D.; CALDAS, R.C. Identificação da coesão com base em atributos físicos convencionais em solos dos Tabuleiros Costeiros. In: WORKSHOP COESÃO EM SOLOS DOS TABULEIROS COSTEIROS, Aracaju, 2001. Anais. Aracaju: EMBRAPA Tabuleiros Costeiros, 2001. p.169-190.

STOOPS, G.J.; JONGERIUS, A. Proposal for a micromorfological classification of soil materials I. A classification of related distribution of coarse and fine particles. Geoderma, v.13, p.189-200, 1975.

STOOPS, G.J.; BUOL, S.W. Micromorphology of Oxisols. In: DOUGLAS, L.A.; THOMPSON, M.L. (Ed.). Soil micromorphology and soil classification. Madison: Soil Science Society of America, 1985. p.105-119. (Special Publication, 15).

THOMPSON, M.L.; SINGH, P.; CORAK, S.; STRASZHEIM, W.E. Cautionary notes for the automated analysis of soil pore-spaces images. Geoderma, v.53, p.399-415, 1992. 
TORMENA, C.A.; SILVA, A.P.; LIBARDI, P.L. Caracterização do intervalo hídrico ótimo de um Latossolo Roxo sob plantio direto. Revista Brasileira de Ciência do Solo, v.22, p.573-581, 1998.

UNIVERSIDADE FEDERAL DE VIÇOSA. Caracterização de solos e avaliação dos principias sistemas de manejo dos Tabuleiros Costeiros do Baixo Rio Doce e das Regiões Norte do Estado do Espírito Santo e sua interpretação para uso agrícola. Viçosa, 1984. 153p.

VEPRASKAS, M.J. Cone index of loamy sands as influenced by pore size distribution and effective stress. Soil Science Society of America Journal, v.48, p.1220-1225, 1984.

WATTS, C.W.; DEXTER, A.R. Soil friability: theory, measurement and the effects of management and organic carbon content. European Journal of Soil Science, v.49, p.73-78, 1998. 